I NTER NATIONAL MONETARY FUND

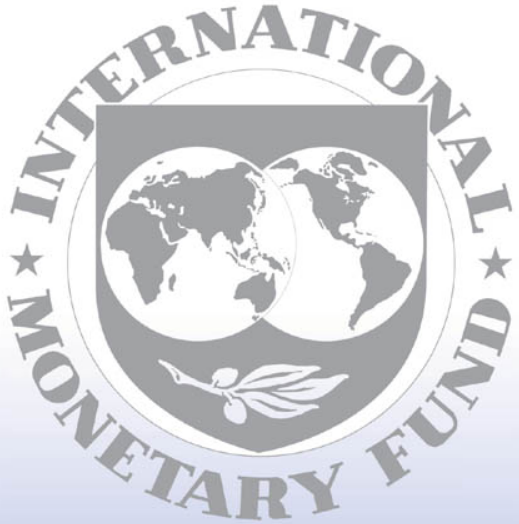

Staff

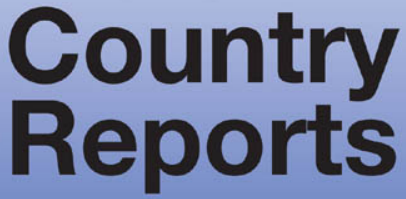




\section{Ukraine: First Review Under the Stand---By Arrangement-Staff Report; Staff Statement; Press Release on the Executive Board Discussion.}

In the context of the first review under the stand---by arrangement, the following documents have been released and are included in this package:

- $\quad$ The staff report for the First Review Under the Stand---By Arrangement, prepared by a staff team of the IMF, following discussions that ended on November 15, 2010, with the officials of Ukraine on economic developments and policies. Based on information available at the time of these discussions, the staff report was completed on December 10, 2010. The views expressed in the staff report are those of the staff team and do not necessarily reflect the views of the Executive Board of the IMF.

- A staff statement of December 22, 2010 updating information on recent developments.

- $\quad$ A Press Release summarizing the views of the Executive Board as expressed during its December 22, 2010 discussion of the staff report that completed the request and/or review.

The documents listed below have been or will be separately released.

Letter of Intent sent to the IMF by the authorities of Ukraine*

Memorandum of Economic and Financial Policies by the authorities of

Ukraine*

Technical Memorandum of Understanding*

*Also included in Staff Report

The policy of publication of staff reports and other documents allows for the deletion of market-sensitive information.

Copies of this report are available to the public from

$$
\begin{gathered}
\text { International Monetary Fund • Publication Services } \\
70019^{\text {th }} \text { Street, N.W. • Washington, D.C. } 20431
\end{gathered}
$$

Telephone: (202) 623-7430 • Telefax: (202) 623-7201

E-mail: publications@imf.org Internet: http://www.imf.org

\section{International Monetary Fund Washington, D.C.}




\section{INTERNATIONAL MONETARY FUND}

\section{UKRAINE}

\section{First Review Under the Stand-By Arrangement}

Prepared by the European Department in Consultation with Other Departments

Approved by Poul M. Thomsen and Lorenzo Giorgianni

December 10, 2010

\section{Executive Summary}

Stand-By Arrangement (SBA). A 29-month SDR 10.0 billion (729 percent of quota, US\$15.3 billion) SBA involving exceptional access was approved by the Executive Board (Country Report No. 10/262) on July 28, 2010. A first purchase of SDR 1.25 billion was made following the Board meeting. The program foresees disbursement of SDR 1.0 billion following the completion of the first review, including approximately US\$1 billion (SDR 655 million) for the budget (bringing 2010 budget support to US $\$ 2$ billion).

Program status. Policy implementation has been broadly in line with the program and all endSeptember quantitative performance criteria were observed. Fiscal performance is broadly on track, though some spending restraint has been necessary to offset small overruns in Naftogaz finances. Bank recapitalization and legislation to strengthen supervision and regulation are also on track.

Key issues. The review focused on: (i) formulation of the 2011 budget; (ii) implications of the tax code for the revenue base and tax administration; (iii) progress in implementing agreed fiscal structural reforms, including pension reforms; (iv) measures to gradually liberalize the foreign exchange framework; and (v) banking sector reforms.

Discussions. During November 3-15, the staff team met with Prime Minister Azarov; Deputy Prime Ministers Kolesnikov and Tihipko; Ministers of Finance Yaroshenko, Labor and Social Policy Nadraha, and Energy Boyko; Governor of the National Bank of Ukraine Stelmakh; First Deputy Chief of Staff of the Presidential Administration Akimova; and other senior officials and representatives of international financial institutions, research institutes, labor unions, and private banking and business communities. The mission also met with members of the opposition. The staff team comprised Mr. Arvanitis (head); Messrs. Dohlman, Roudet, and Atoyan (EUR); Mr. Ljungman (FAD); Mr. Olafsson (MCM); and Mr. Chensavasdijai (SPR). Mr. Alier (resident representative) assisted the mission. The mission cooperated closely with World Bank staff on structural issues. Mr. Yakusha, Alternate Executive Director for Ukraine, attended most meetings. 


\section{Contents}

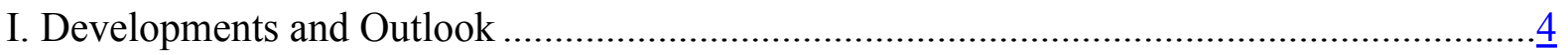

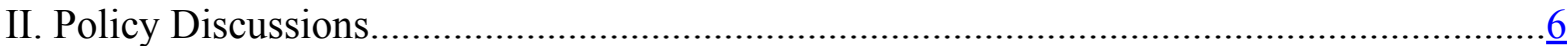

A. Securing Fiscal Adjustment ............................................................................

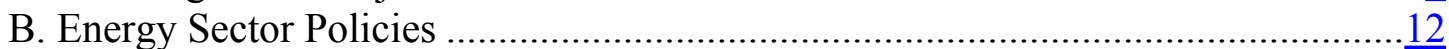

C. Monetary and Exchange Rate Policy ………….................................................13

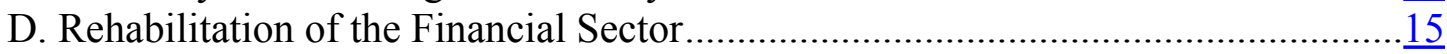

III. Program Modalities, Capacity to Repay, and Safeguards Assessment................................16

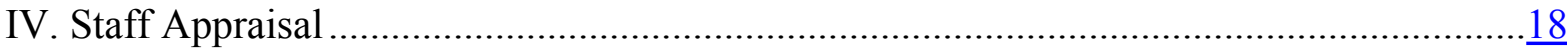

\section{Boxes}

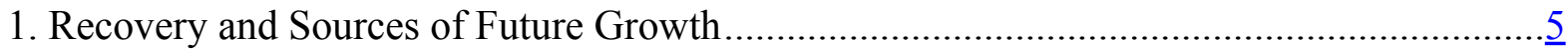

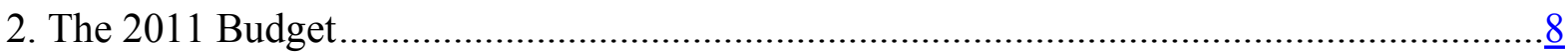

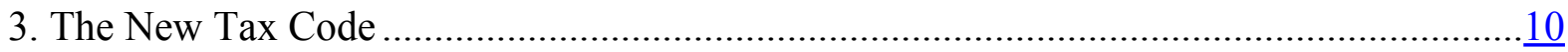

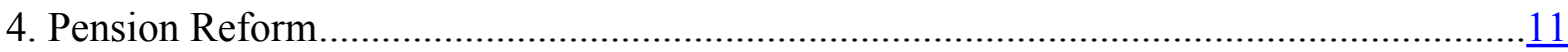

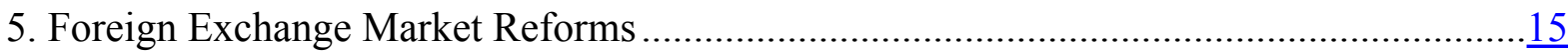

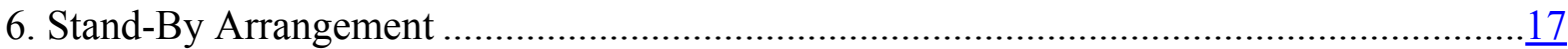

\section{Figures}

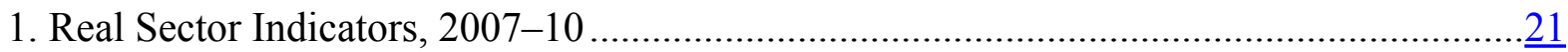

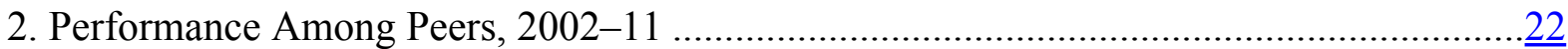

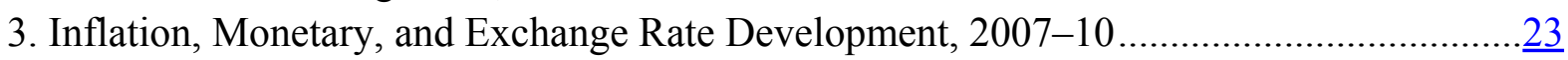

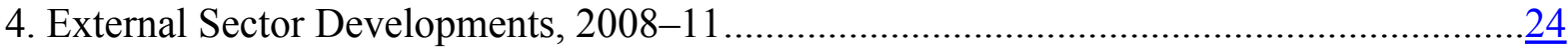

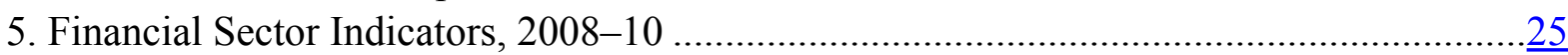

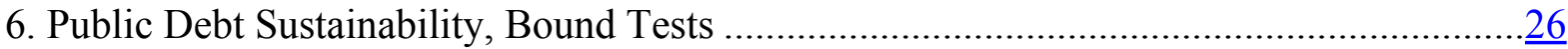

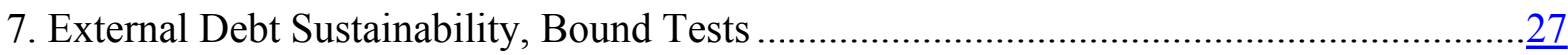

\section{Tables}

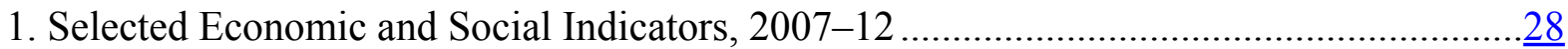

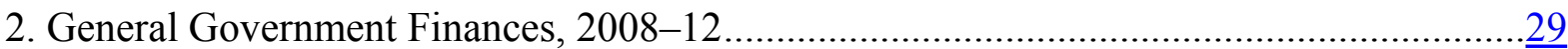

3. Gross Financing Requirements for General Government, 2010-11 .................................

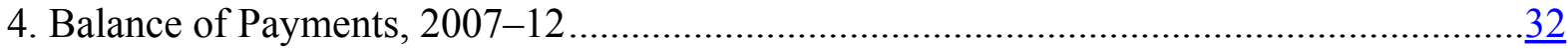

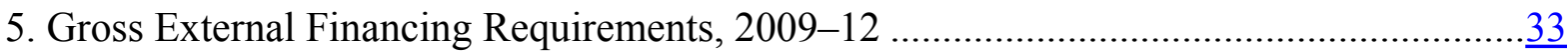

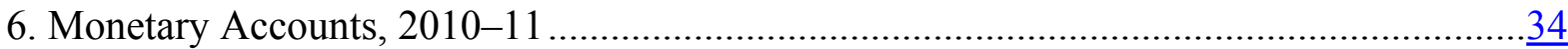

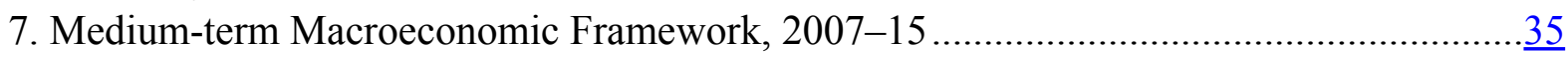

8. Financial Soundness Indicators for the Banking Sector, 2006-10 ....................................

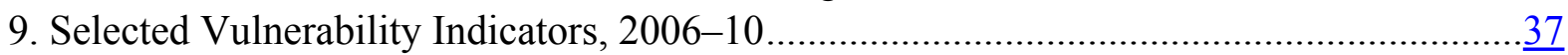

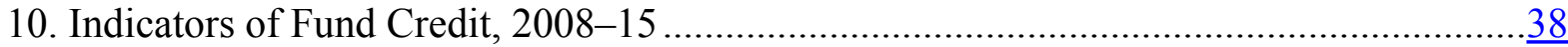

11. Public Sector Debt Sustainability Framework, 2005-15 ……....................................

12. External Debt Sustainability Framework, 2005-15 ………………............................... 


\section{Appendix}

Letter of Intent and Memorandum of Economic and Financial Policies (MEFP), and Technical Memorandum of Understanding 


\section{DEVELOPMENTS AND OUTLOOK}

1. The economic recovery continues to broaden, with the policy focus gradually shifting from crisis management to supporting adjustment and recovery. After

experiencing one of the sharpest downturns in the region in 2009, real GDP growth in the first half of 2010 was better than expected (5.9 percent y-o-y), helped by export-oriented industries, particularly steel. More recently, domestic demand has gained momentum on the back of improving consumer and business confidence and robust wage growth (Figure 1). As a result, and notwithstanding a lower grain harvest due to bad weather conditions, GDP growth is set to reach, or slightly exceed, the program projection of $33 / 4$ percent for 2010 . Growth is expected to increase to $4 \frac{1}{2}$ percent in 2011 helped by stronger private consumption and investment (including for the Euro 2012 soccer tournament). However, the output gap remains sizable and economic activity is not expected to surpass the pre-crisis peak until 2013 (Box 1).

\section{Headline inflation is trending down, but remains above peers (Figures $\mathbf{2}$ and 3).}

After several months of low or negative inflation, consumer prices jumped in September to 10 percent following higher food prices and hikes in gas tariffs and excise taxes. Inflation resumed a downward path later in the year and remains within the program objectives. In 2011, administrative price increases will continue to keep headline inflation high, but policies under the program and the remaining output gap are expected to restrain secondround inflationary pressures. Core inflation is projected to fall to around 7 percent by yearend.

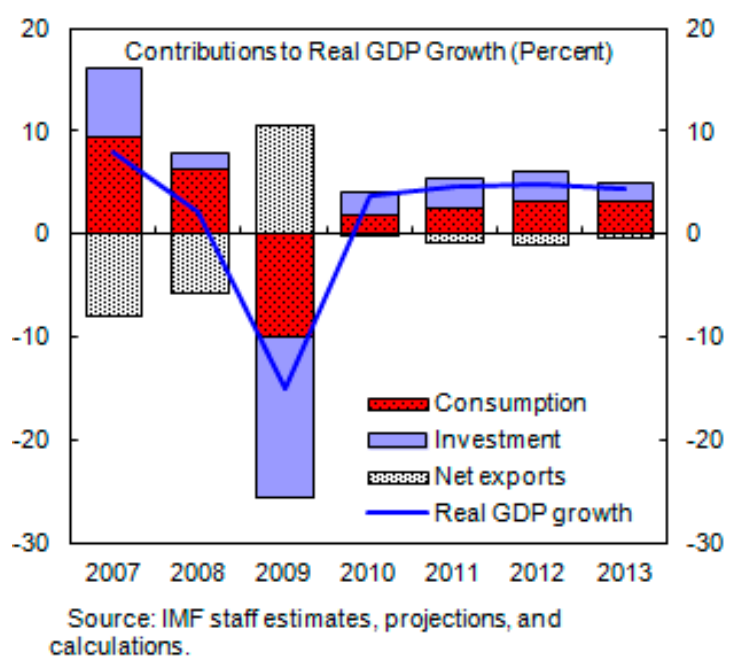

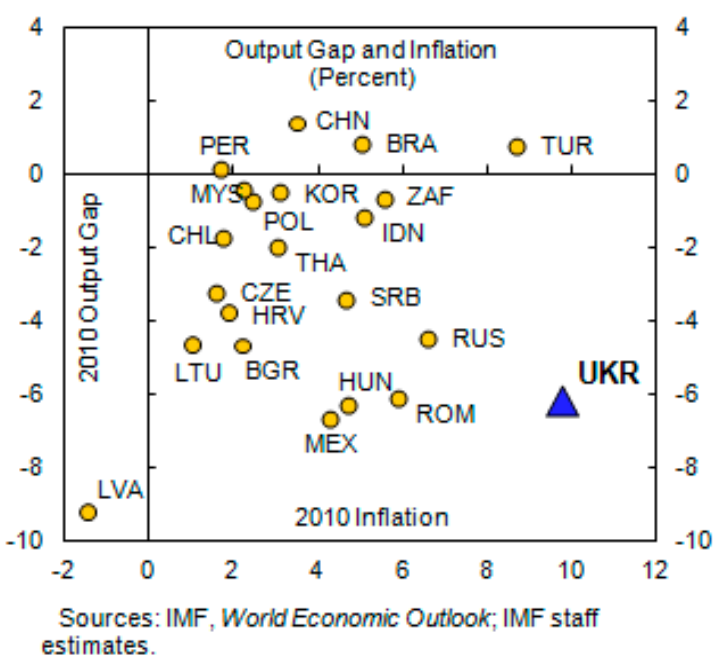




\section{Box 1. Ukraine: Recovery and Sources of Future Growth}

Strengthening domestic demand is expected to increasingly support growth. While the initially recovery was driven by net exports benefiting from the rebound in commodity prices (particularly the recovery in global demand for steel products), this support is fading as imports rebound and steel prices soften. In its place, firming consumer and business confidence and lower interest rates are expected to revive consumer spending and boost domestic demand. Higher investment spending for Euro 2012 will provide further support to economic activity.

In the medium term, stronger policies and improvements in productivity and the business climate will be necessary to support high and sustained growth. A recent study by the World Bank (Strategic Choices to Accelerate and Sustain Growth in Ukraine, 2010) identified several impediments to higher long-term growth, including: (i) macroeconomic imbalances,

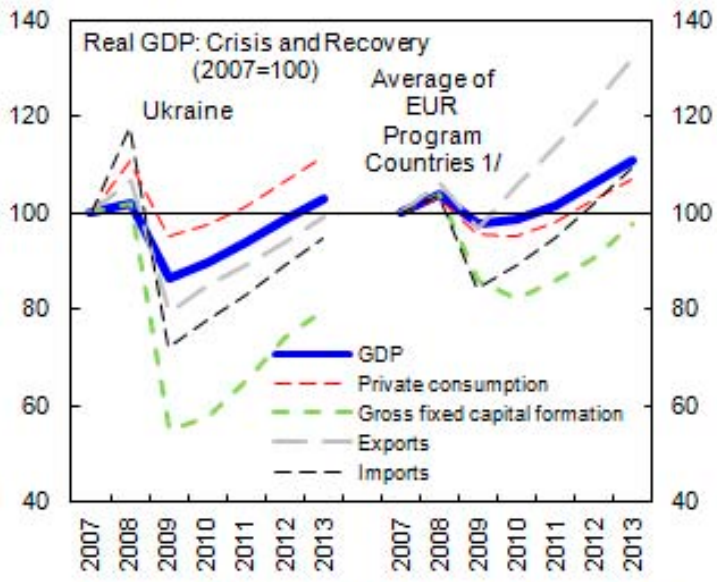

Sources: IMF, World Economic Outlook; and IMF staff estimates, projections, and calculations.

$1 /$ Includes Bosnia, Hungary, Latvia, Moldova, Poland, Romania, and Serbia.

particularly fiscal policy, that deter capital inflows; (ii) high marginal tax rates and compliance costs compared with other countries; (iii) deteriorated infrastructure; (iv) an increasing shortage of technical skills; (v) significant deficiencies in property rights enforcement; (vi) high barriers to entry and operational costs, particularly for export sectors, that hamper the economy's ability to allocate resources efficiently; and (vii) governance and corruption concerns that discourage FDI. Strong policies and acceleration of structural reforms to address these problems will be necessary to support growth performance in the coming years.

\section{Ukraine has regained access to international capital markets helped by stronger}

fiscal and external positions (Figure 4). Following sovereign rating upgrades over the summer, the government placed a US\$2 billion Eurobond (7.5 percent yield), marking its first issuance since late 2007. Banks and corporates have also tapped the Eurobond market this year and local currency government bonds have seen increased interest from foreign investors. These positive developments facilitated a buildup in gross international reserves to US\$33.2 billion as of end-

November. However, risk perceptions remain high, as reflected in the lowest sovereign rating in Eastern Europe and spreads persistently above 500 basis points, and market conditions remain volatile. Since September, the National Bank of Ukraine (NBU) has become a net seller of foreign currency - mostly due to seasonal factors but also higher-than-anticipated demand

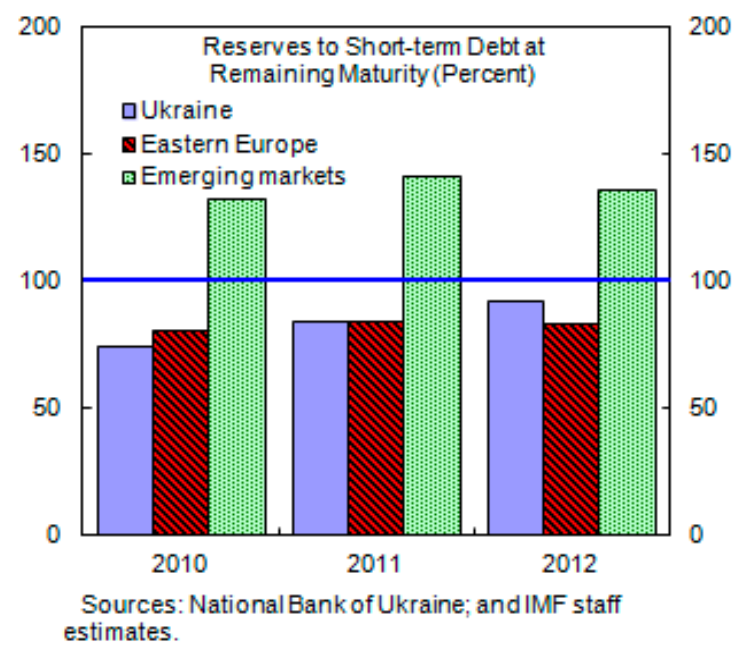


for imports. For 2011, the balance of payments outlook remains positive and strong FDI and IFI flows are expected to cover the modest current account deficit. This should support a further strengthening of Ukraine's reserves position, which is still below comfortable levels.
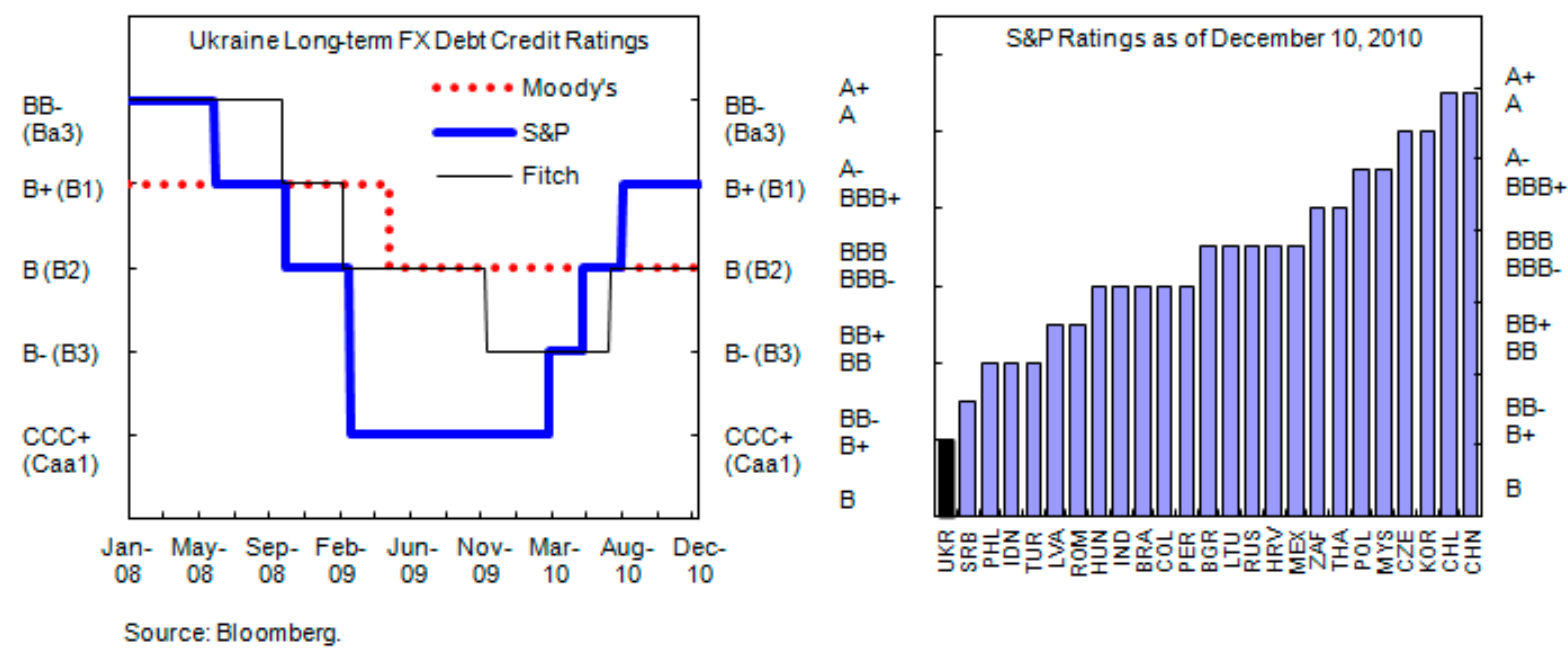

4. Financial sector conditions are slowly improving, but banks remain under strain

(Figure 5). Deposits are slowly returning to banks and, in November, they surpassed their pre-crisis levels. Funding costs are coming down as deposit rates have dropped considerably. However, the sector remains unprofitable, with a return on assets of around -2 percent. High NPL levels represent a major challenge to bank balance sheets and the resumption of lending, with weaknesses in the legal, tax, and judicial systems preventing more aggressive resolution of bad loans. As a result, and notwithstanding that the banking system as a whole is highly liquid, anemic credit growth conditions have continued this year. Lending to households remains stalled due to perceived high credit risks, though credit to enterprises has shown some signs of revival recently.

5. The program is off to a generally good start, though with some delays. All endSeptember fiscal performance criteria and the indicative ceiling on the stock of VAT refund arrears were met. The issuance of bank recapitalization bonds and government guarantees are within program ceilings. Robust capital inflows have allowed the NBU to meet the endSeptember NIR floor by a comfortable margin. The NDA target was also met. All three structural benchmarks were completed, though two-lifting the ban on penalties for overdue utility bill payments (reset as prior action) and agreement on phasing out restrictions on the foreign exchange market—were met with delay (Appendix Table I.2).

\section{Policy Discussions}

\section{Against a broadly unchanged domestic and external outlook, the policy}

framework remains appropriately centered around four pillars: (1) restoring confidence and fiscal sustainability; (2) implementing gas sector reforms and phasing out the deficit of Naftogaz; (3) strengthening the monetary and foreign exchange policy framework; and (4) restoring and safeguarding banks' soundness. 


\section{A. Securing Fiscal Adjustment}

7. The authorities are on track to meet the $\mathbf{2 0 1 0}$ fiscal deficit targets. However, sustained efforts will be necessary to keep spending under control in the final weeks of the year and improve tax administration to eliminate delays in VAT refunds.

- Fiscal performance is broadly in line with the program. General government revenue increased at a somewhat slower pace than envisaged in the year to September, but tight expenditure control kept the deficit under the program ceiling. Better revenue performance in the final quarter, supported by higher non-tax revenue and accelerating retail trade and imports, is providing some fiscal space against the end-December general government deficit target. The authorities are committed to saving this over performance to meet the combined general government and Naftogaz deficit ceiling, as Naftogaz's deficit is expected to exceed the end-year target by about 0.3 percent of GDP (see $\$ 12$ ).

- The stock of VAT refund arrears is nearly phased out. Arrears peaked at UAH 25 billion (2.3 percent of GDP) in mid-2010 and then declined through issuance of VAT bonds (1.5 percent of GDP) and cash payments. The end-September indicative ceiling of VAT arrears (UAH 3 billion) was met. However, in view of administrative delays in processing claims and budgetary constraints, the authorities have requested a modification of the end-December indicative target to allow for a small amount of arrears (0.1 percent of GDP). They are committed to eliminating all arrears in early 2011 and will introduce a more systematic process for refunds by January 2011 (MEFP $\$ 13$ ).

8. Fiscal consolidation is set to continue in 2011. The program aims to reduce the combined general government and Naftogaz deficit ceiling to $3 \frac{1}{2}$ percent of GDP. However, the breakdown of the fiscal targets has slightly changed as a budgetary transfer to Naftogaz - a practice of partially compensating Naftogaz for charging utility companies below cost recovery tariffs - is being terminated. While this does not affect the overall adjustment or underlying policies, it would reduce the general government deficit and increase Naftogaz's deficit by an equivalent amount.

Fiscal Indicators

(Percent of GDP)

\begin{tabular}{lrrrrrrr}
\hline & 2009 & \multicolumn{2}{c}{2010} & & \multicolumn{2}{c}{2011} \\
\cline { 3 - 4 } & & & Prog. & Rev. & & Prog. & Rev \\
\hline Total debt 1/ & 35.3 & 39.5 & 41.7 & & 42.7 & 42.4 \\
General government deficit & 6.3 & 5.5 & 5.1 & 3.5 & 3.1 \\
Naftogaz deficit & 2.5 & 1.0 & 1.4 & & 0.0 & 0.4 \\
Bank recapitalization bonds $2 /$ & 2.5 & 1.8 & 1.8 & & 0.0 & 0.0 \\
VAT bonds & $\ldots$ & 1.5 & 1.5 & & $\ldots$ & $\ldots$ \\
State guarantees & 2.1 & 1.4 & 1.4 & & $\ldots$ & 1.2 \\
\hline
\end{tabular}

Sources: Ukrainian authorities; and IMF staff estimates.

1/ Includes State and local government direct debt, total IMF debt, and Stateguaranteed debt. Upward revision compared to 2010 program data reflects revised local government debt and higher accumulation of deposits at end year (unspent

2/ Amounts budgeted for but not used in 2010 may be carried into 2011.

\section{In line with this, the 2011 general government budget submitted to parliament} targets a deficit of 3.1 percent of GDP, (prior action) (Box 2). The implied tightening of the cyclically adjusted general government primary balance of about 1 percent of GDP is feasible and necessary to strengthen public finances and slow the accumulation of public 
debt. As revenues are projected to decline by about $12 / 3$ percent of GDP - mainly on account of lower non-tax revenue, especially NBU profit transfers - the authorities are determined to achieve the adjustment through spending consolidation, while protecting capital and social protection outlays.

Measures include: (i) reduction in the public wage bill by freezing real wages, curtailing employment, reducing bonuses, and cutting top-ups; (ii) reduction in subsidies and discretionary spending on goods and services; and (iii) consolidation of pension spending by limiting increases and enacting pension reforms.
Decomposition of Expenditure Changes, 2010-11

\begin{tabular}{lrr}
\hline & \multicolumn{2}{c}{$\begin{array}{c}\text { Billions of } \\
\text { Ukrainian }\end{array}$} \\
& $\begin{array}{c}\text { Percent of } \\
\text { hryvnias }\end{array}$ & GDP 1/ \\
\hline 2010 Expenditure & 524.3 & 48.4 \\
Passive 2/ & 42.2 & 3.4 \\
Interest expenditure & 8.6 & 0.7 \\
Discretionary policy measures & -14.9 & -1.2 \\
Of which: expendiure cuts & -23.2 & -1.9 \\
Cuts in the wage bill & -12.0 & -1.0 \\
Cuts in goods and services & -2.2 & -0.2 \\
Cuts in subsidies to enterprises & -3.7 & -0.3 \\
Pension reforms & -4.8 & -0.4 \\
Other & -0.5 & 0.0 \\
Of which: expenditure increases & 8.2 & 0.7 \\
$\quad$ Higher capital investment & 8.2 & 0.7 \\
2011 Expenditure & 560.2 & 44.7 \\
\hline
\end{tabular}

Source: IMF staff estimates.

$1 / 2010$ and 2011 expressed against different GDP basis.

2/ Macro effect (increase necessary to keep 2010 policies constant in 2011). See Box 2.

\section{Box 2. Ukraine: The 2011 Budget}

Revenues. With the tax code broadly revenue neutral, and no other tax policy changes envisaged in the near term, tax revenues are expected to remain broadly unchanged as a share of GDP. However, lower NBU profit transfers and several non-tax revenue items that are fixed in nominal terms are expected to reduce overall revenue by 1.7 percent of GDP in 2011.

Expenditures. To meet the 3.1 percent of GDP deficit target, the budget envisages a number of measures to reduce spending by 3.7 percent of GDP, including:

- Limiting increases of a number of expenditure items, particularly average wages and pensions, to inflation (passive effect) will result in 3.4 percent of GDP reduction in spending.

- Wage-related expenditure cuts of an additional 1.0 percent of GDP by reducing the number of staff positions and eliminating some bonus and top-up regimes for civil servants.

- Reduction of spending on goods and services by 0.2 percent of GDP.

- Enactment of pension reform legislation by end-December (structural benchmark) will generate 0.4 percent of GDP in savings.

- Reduction of transfers to enterprises of 0.3 percent of GDP.

These cuts will be partially off-set by discretionary and interest expenditure increases:

- Increased allocations for investment, including for Euro 2012, of 0.7 percent of GDP.

- Higher interest payments by 0.5 percent of GDP.

- Increased spending on household transfer programs to protect vulnerable groups against utility price hikes ( 0.1 percent of GDP).

In addition, some specific operations not reflected in the general government deficit are expected to add to public debt in 2011. The government plans to issue guarantees of 1.2 percent of GDP. The budget also provides for the recapitalization of state-intervened banks, limited to unused amounts carried over from 2010. 
10. To start rebalancing spending priorities, the budget increases capital spending to about 3 percent of GDP. The authorities consider this necessary to meet project commitments for the Euro-2012 tournament (see Country Report No. 10/262) and for basic infrastructure upgrades which were compressed in recent years. They also view selected infrastructure projects to be delivered by private entities and state enterprises as critical and plan to facilitate these through state loan guarantees. Staff cautioned that state guaranteessome of which finance off-budget investment and thereby amount to an effective loosening of the fiscal stance - should not undermine the envisaged fiscal adjustment and argued that careful prioritization and valuation of projects is needed to ensure high returns and mitigate public risks. To control overall public sector indebtedness, state guarantees will be limited to UAH 15 billion (1.2 percent of GDP), the same level as in 2010 .

\section{Major structural reforms under way will help improve the fiscal framework and support efforts to rationalize current spending over the medium term:}

- A new tax code (Box 3). After considerable public opposition to some amendments, the new code adopted in early December aims to reform the complex tax system, reduce the tax burden over time, strengthen administration and improve compliance. While recognizing these objectives, staff expressed concern that rapid tax cuts and the proliferation of exemptions would drain revenues and threaten fiscal targets. The authorities agreed to slow down corporate profit tax rate cuts to two percentage points per year through 2013. They also agreed to limit VAT exemptions for certain business and professions to a 3-year period. Overall, while the code introduces some welcomed changes in tax policy, it is also a missed opportunity to improve further the quality of tax legislation and administration. If successfully implemented, staff believes the new code would have a broadly neutral revenue impact in 2011, and gradually reduce revenues over the medium term. The authorities agreed that any sign of revenue underperformance in 2011 would be met by swift action to reduce expenditure. Going forward, it would be important to carefully administer and implement the changes under the code to reduce the discretionary elements of the tax system, which have unduly burdened the business community in the past.

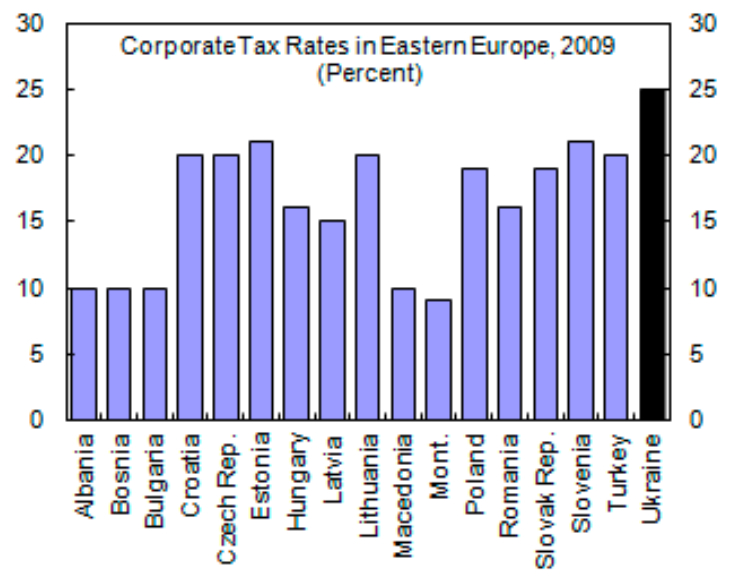

Sources: European Commission; OECD; PWC; Chen, D. and J. Mintz, 2010; and IMF staff estimates and calculations. 


\section{Box 3. Ukraine: The New Tax Code}

The new tax code consolidates most existing tax legislation and launches significant tax policy and administration changes. The authorities have sought to reduce the tax burden and create incentives for small business owners in the hope of stimulating growth and job creation. On balance, staff estimates the code's impact as broadly fiscally neutral in 2011, though with downside risks given potential implementation challenges. The main changes introduced by the code are:

- Elimination of many small taxes (reducing revenue by some 0.2 percent of GDP in 2011).

- Tax rate cuts. The corporate tax rate will be cut from 25 percent by two percentage points each year through 2013, to 19 percent, and then gradually reduced to 16 percent by 2016 . The VAT rate will be reduced by 3 percentage points in 2014, to 17 percent. These measures will reduce revenues by about 0.2 percent of GDP in 2011 .

- New taxes and increases in existing rates: The code introduces a property tax for large homes, increases the personal income tax on large incomes from 15 to 17 percent, and increases a number of excise and other tax rates (generating about 0.4 percent of GDP in revenues in 2011).

- Tax holidays and exemptions. The code introduces new tax holidays for small enterprises and specific industries (hotels, shipbuilding and aerospace industry), and a 3-year VAT exemption for several sectors that are subject to significant VAT refund fraud. While the overall revenue impact of these measures is likely to be small, they bring unwelcome distortions, add to existing exemptions, and break the VAT chain.

- Changes to the calculation of the corporate profit base and amendments to tax deduction rules. These measures aim at closing a number of loopholes in the existing system.

- Pension reforms (Box 4). The pay-as-you-go public pension fund system is facing acute financial difficulties and requires large transfers from the state budget to finance rising pension spending (which at around 18 percent of GDP is one of the highest in the world). Without adjustment, demographic pressures will aggravate the current situation further in the coming years. To restrain pension spending and reduce pension deficits, legislation is expected to be submitted to Parliament by mid-December (prior action). Key elements include increasing the minimum qualification periods to receive minimum and full pension benefits and gradually equalizing the retirement ages for men and women at 60 years. The reforms are estimated to bring immediate savings of about 0.4 percent of GDP in 2011, gradually rising to about 2.5 percent of GDP per annum over the long term. While the current efforts will help contain budget pressures, further reforms will be needed in the future to ensure the long-run financial sustainability of the pension system. 


\section{Box 4. Ukraine: Pension Reform}

Ukraine's pension system is on an unsustainable path, and Ukraine is one of the last in the region to embark on reforms. Pension expenditures as a share of GDP increased from 9 percent in 2003 to a projected 18 percent in 2010; one of the highest levels in the world. Pension fund revenues have not increased at the same pace, and large transfers, projected to reach 7 percent of GDP in 2010, from the central government are needed each year to balance the accounts. This situation is the result of underlying structural weaknesses (Box 5, Country Report No. 10/262) and demographic trends. It is expected to deteriorate further over the next 15 years as the number of contributors is projected to decrease by 25 percent and the number of recipients is projected to increase by 8 percent.

Options to reform the system are limited. Contribution rates are already high by international standards, and replacement ratios (pension benefits to wages) are low. Increasing the retirement age and contribution periods and tackling privileges under special regimes are necessary steps.

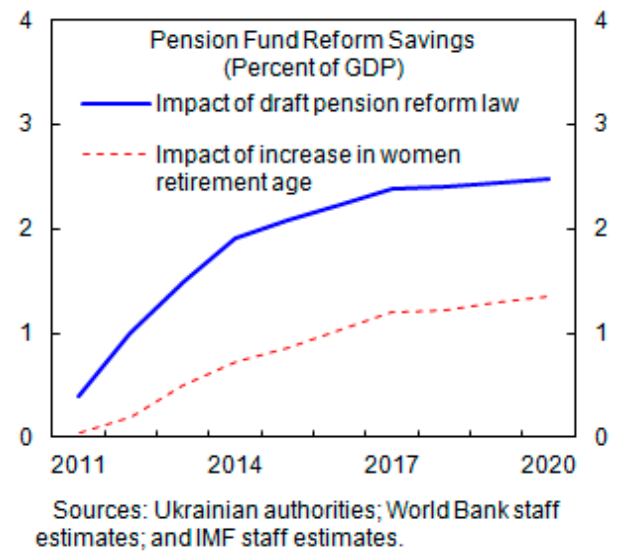

A draft law will be submitted to parliament to initiate pension reform (prior action). The authorities have agreed to: (i) equalize the retirement ages for men and women by gradually increasing the retirement age for women to 60 , by 6 months every year, starting in 2011; (ii) increase the qualification period to receive full pension benefits by 10 years; (iii) increase the minimum insurance period from 5 to 15 years; (iv) change the base for the 1 percent increase for every additional year worked over the minimum contribution period for full pension; and (v) cap large pensions and reduce benefits for working pensioners in special regimes. The authorities estimate that these measures could bring savings of about 0.4 percent of GDP in 2011, gradually reaching 2.5 percent of GDP per annum over the long run.
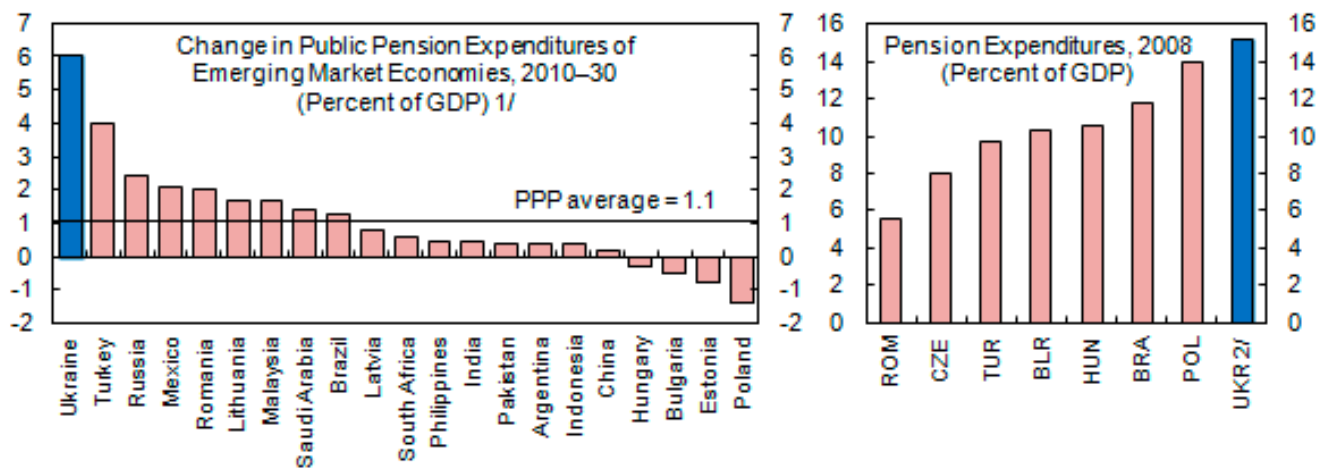

Sources: Country authorities; EC; OECD; ILO; World Bank; and IMF staff estimates.

1/ Average weighted by PPP-adjusted GDP.

2/Pension expenditure exceeded 18 percent of GDP in 2009

- Public sector reform. Measures to reduce the public sector wage bill and improve the efficiency of the public sector are underway. A functional review of all budgetary institutions is expected to be completed shortly, aiming to identify a better structure for central government administration and eliminate redundancies and overlaps. A more comprehensive public administration reform plan to improve the efficiency and quality of public services is expected to be completed by end-March (structural benchmark). While this reform is not expected to yield notable savings in 2011, it will help reduce the cost of government over the medium term, particularly as it reaches into the critical sectors of health and education. 


\section{B. Energy Sector Policies}

\section{Naftogaz's finances are improving, but at a slower-than-expected pace.}

Naftogaz's deficit is projected to exceed the end-year target by UAH 3 billion (reaching 1.4 percent of GDP) as: (i) domestic gas consumption has been lower than anticipated; (ii) some utility companies have been unable to remain current on payments to Naftogaz due to delays in passing through the recent gas price hikes to end-users; and (iii) collection rates have not sufficiently improved, hurt by a delay in removing the ban on penalties for overdue payments (missed structural benchmark for end-September). The authorities have agreed to pass legislation to remove the ban (prior action), and NERC (the interim utility price regulator) will issue instructions to communal utilities to raise end-user heating tariffs (effective January 1, 2011) to reflect the August increases (prior action). In addition, the new independent regulator for utility prices is expected to be fully operational by

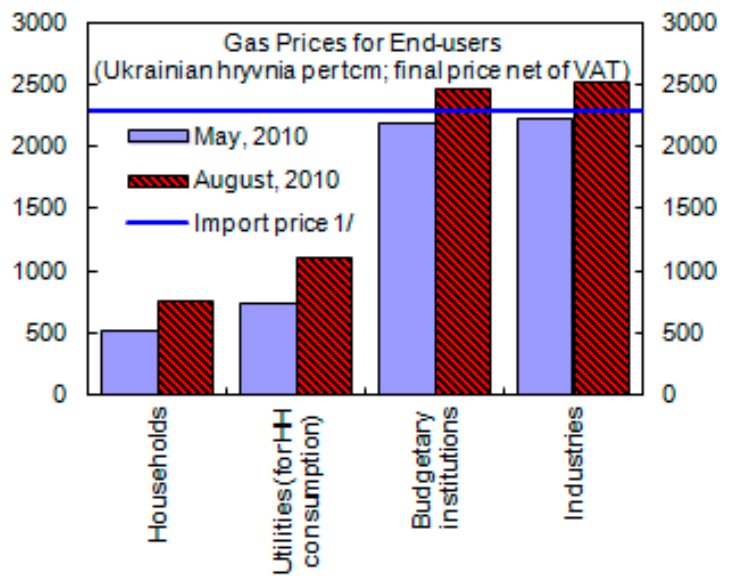

Sources: Ukrainian authorities; and IMF staff estimates. $1 /$ As of August, incudes transportation fees for comparability.

January 2011.

\section{Naftogaz's deficit is expected to fall to 0.4 percent of GDP in 2011, boosted by a} second round of gas tariff hikes next year. As end-user prices remain well below the cost of gas imports, a further 50 percent tariff hike will go into effect by April (structural benchmark), with further increases as needed during the year to achieve the 2011 deficit target, and to balance Naftogaz's financial position by 2012. These increases will be supplemented by strict enforcement of full price pass-through, better compliance from lifting the ban on penalties, and tight control over operational costs. Risks to this projection include uncertainty over import gas prices - as the authorities have sought to renegotiate the gas contract with Gazprom - and the strength of domestic demand.

\section{Naftogaz has reached a settlement of the Stockholm arbitration case with}

RosUkrEnergo (MEFP, q16). The settlement results in a net liability for Naftogaz of about US\$ 1.5 billion. The purchase of natural gas for delivery to RUE will be facilitated by an advance payment of transit fees from Gazprom, which will be extinguished over the 2011-15 period through foregone gas transit revenues. Program adjustors have been included so that the settlement does not affect the headline deficit targets for Naftogaz under the program. The recognition of this fiscal risk (Country Report No. 10/262) points to the need for continued efforts to strengthen Naftogaz's finances, including through measures to boost its revenue and reforms to improve the functioning of the gas market and the transit system.

\section{Broader energy sector reforms are advancing, although stronger engagement}

with IFIs is needed. Structural reforms are important both to enhance energy efficiency- 
Ukraine is one of the least energy efficient countries in the world - and to modernize the legal and investment infrastructure of the energy sector to ensure efficient and reliable delivery of gas to Ukraine and Europe. The protocol for Ukraine's accession to the Energy Community Treaty was signed in September, following approval of the gas sector law adopted in July, which included provisions for restructuring Naftogaz (end-December structural benchmark). Ukraine's parliament is expected to ratify the treaty soon. A $€ 610$ million EU macro-financial assistance loan, which includes energy sector conditionality, has been delayed and is now expected to be disbursed in 2011. Further efforts are needed to speed up progress on pilot projects for modernization of LNG facilities and the gas transit system with EBRD and EIB involvement—in line with the Brussels Declaration.

\section{Monetary and Exchange Rate Policy}

16. The NBU has recently begun to tighten monetary conditions, given upside risks to inflation. For much of 2010, disinflation, rising deposits, robust capital inflows, and a large output gap provided the NBU with room to gradually lower its refinancing rate by 225 basis points to 8.75 percent. With ample liquidity in the system, overnight rates have remained well below policy rates. In September, responding to downward pressure on the exchange rate and rising inflation expectations following the spike in headline inflation, the NBU began tightening liquidity conditions by stepping up placements of CDs, repo operations, and outright sales of government securities. The NBU has also been encouraging early repayment by stronger banks of emergency liquidity support granted during the crisis.

\section{Looking forward, monetary policy should be geared toward reaching the} projected disinflation path, within a more flexible exchange rate regime. While core inflation has stayed broadly flat in recent months, vigilance against second-round effects and rising inflation expectations is needed, including by further mopping up liquidity and raising policy rates if necessary. The NBU should also diminish its regular participation in the foreign exchange market, where it has been clearing excess demand and steering the hryvnia within a narrow band against the US dollar. 
NBU's Liquidity Management Operations

The NBU has stepped up liquidity absorption...

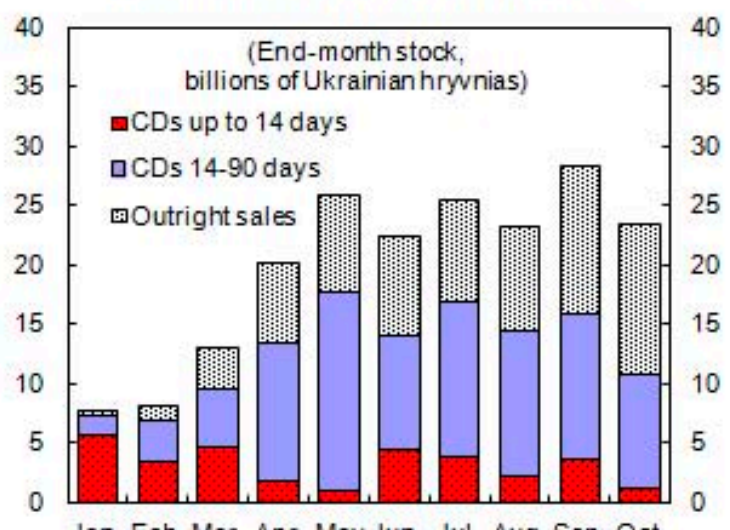

Jan. Feb. Mar. Apr. May Jun. Jul. Aug. Sep. Oct.

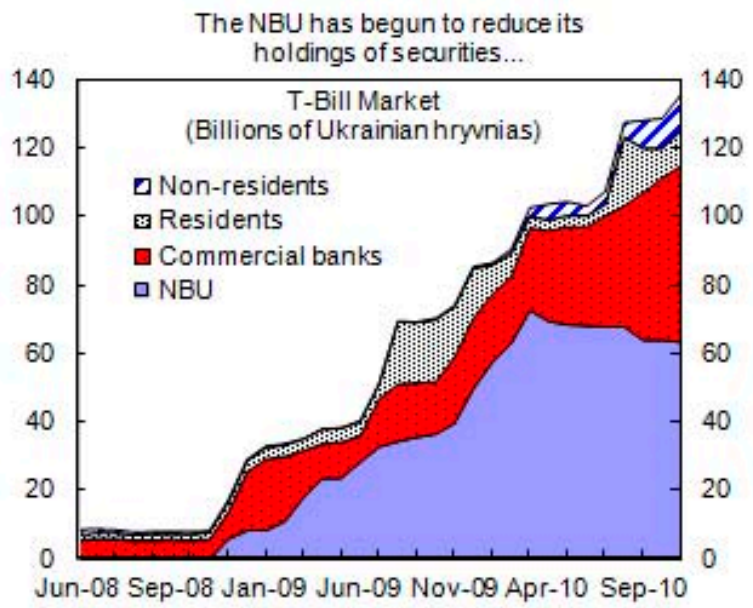

...significantly reducing excess liquidity.
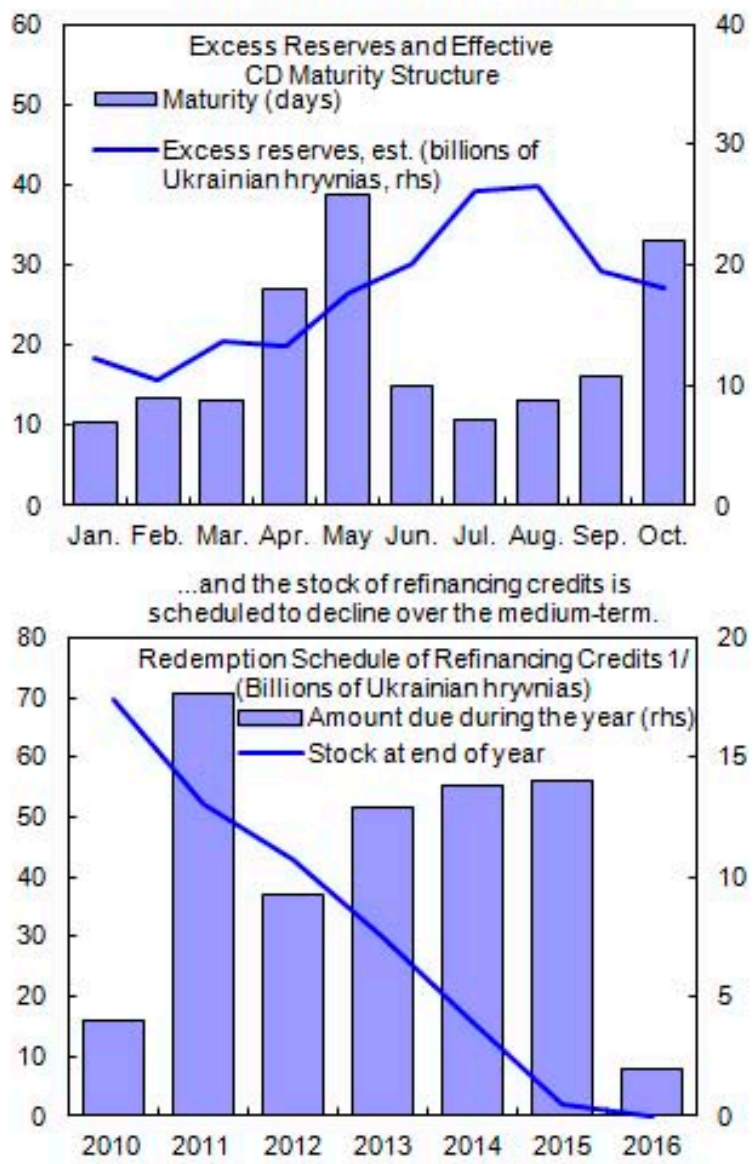

Sources: National Bank of Ukraine; and IMF staff calculations.

$1 /$ Amount for 2010 is for refinancing credits maturing in November-December.

\section{Gradual foreign currency market liberalization will facilitate a shift towards}

greater exchange rate flexibility. The authorities have been concerned that volatile capital inflows could lead to destabilizing exchange rate movements. In a precautionary move in early August, the NBU re-imposed a 20 percent reserve requirement on short-term inflows that was suspended in late 2008. Staff noted that, thus far, capital inflows have been very small - mostly directed at purchases of government securities - and have helped reduce the government's domestic cost of borrowing. Staff reiterated that increased exchange rate flexibility is important for focusing monetary policy more squarely on price stability, providing a buffer against external shocks, and discouraging dollarization and excessive risktaking. To facilitate this shift, agreement was reached on a schedule to gradually improve the functioning of the foreign exchange market, drawing from the recommendations of a recent MCM mission (Box 5). Near-term measures include: (i) bringing the regulatory framework for banks' net open foreign exchange position in line with international practice by gradually allowing full deductibility of loan loss provisions, beginning end-June 2011 (structural benchmark); and (ii) setting up a framework for forward transactions between banks by endJune 2011 to facilitate better management of exchange rate risks (structural benchmark). As 
envisaged under the program, legislation has been adopted that eliminates the foreign exchange transactions tax (end-December structural benchmark).

\section{Box 5. Ukraine: Foreign Exchange Market Reforms}

The NBU has agreed to introducing greater flexibility in the foreign exchange (fx) market in line with the attached MEFP (structural benchmark). Measures the NBU has discussed in this regard include the following:

Facilitating Foreign Exchange Market Operations

- Eliminate the pension tax on fx transactions;

- Eliminate requirement that banks first settle fx transactions in-house before trading in the interbank market;

- Allow banks to buy foreign exchange for open position without underlying transactions;

- Allow banks to trade on both sides of the interbank market during the same day;

- Eliminate requirement that residents obtain a certificate of expert pricing evaluation for foreign trade transactions when buying fx and transferring it to non-residents; and

- Eliminate requirement that foreign investors rely solely on authorized banks for conversion of hryvnia into foreign currency before transferring abroad.

Enhancing Exchange Rate Determination

- Use exchange rates for government transactions with the NBU that do not deviate from the contemporaneous exchange rate in the interbank market by more than 2 percent;

- Eliminate the NBU's authorization to introduce limits on fx market spreads; and

- Allow cash bureaus to change their exchange rate quotes during the day.

Strengthening Risk Management

- Align the methodology for calculation of the open foreign exchange position with the best international practice, by gradually allowing full deductibility of loan loss provisions; and

- Allow forward and swap transactions between banks.

\section{Rehabilitation of the Financial Sector}

\section{Resolution and recapitalization of the banking system is broadly on track}

(MEFP, ๆ20). Private banks are expected to meet their recapitalization commitments by end year (structural benchmark) which, when completed, would represent an important milestone in the bank rehabilitation program. The resolution of Nadra Bank is progressing, with completion of the external audit (end-October structural benchmark) showing a capital shortfall of about UAH 8.8 billion. The government and the NBU are now considering options to fully resolve the bank, including selling it to a private investor, in line with the objectives of returning the bank to profitability at the least cost to government. Three other state recapitalized banks remain under temporary administration, with resolution likely delayed until early next year (and thereby any related recapitalization plans), pending findings of a financial advisor and further NBU review. Due diligence studies of the two state banks are on track to be completed by year-end (structural benchmark), and will form the basis for strengthening these banks, as needed.

\section{Legislation to strengthen the financial sector framework has been submitted to}

Parliament. Approval of the ultimate controller and the consolidated supervision draft 
legislation would represent important steps toward increasing transparency and addressing related lending issues (MEFP, $\mid 25)$.

21. High NPLs must be addressed before lending can rebound. The government recognizes that the legal, tax, and judicial framework for addressing NPLs remains weak, and formed a working group to coordinate work in this area. Progress will be critical for completing the rehabilitation of the banking sector, and reviving lending (MEFP, $¥ 24)$.

\section{Addressing Non-Performing Loans}

High NPLs have weakened bank balance sheets and threaten to act as a drag on new lending. NPLs range from 17 (narrow definition) to 41 percent (broad definition) of total loans (Figure 5).

To address the problem, a working group chaired by the NBU is overseeing key reforms:

- Legislative. A corporate insolvency law is being prepared with IMF and WB input for adoption by end-June (structural benchmark), and is expected to include an out-of-court component. An overhaul of the personal bankruptcy code is also needed, and the authorities are considering technical assistance in this area.

- Tax. Two key tax issues are: (i) tax deductibility of loan loss provisions (addressed in the new tax code); and (ii) tax deductibility of loan write-downs or sale to third parties.

- Regulations. The NBU plans to modernize regulations governing NPLs and provisioning in the first half of 2011, with support from IMF experts.

- Other. Other reforms are needed such as strengthening the security of collateral and the efficiency of the judicial system.

\section{Program Modalities, Capacity to Repay, and Safeguards Assessment}

\section{The attached Letter of Intent (LOI) describes the authorities' progress in} implementing their economic program and sets out conditionality through June 2011 (Box 6). Program performance will continue to be monitored by quarterly quantitative performance criteria and structural benchmarks. The list of quantitative performance criteria and indicative targets remains the same. The end-December monetary targets remain valid (but an adjustor has been included, TMU \6), and quarterly targets are set through end-June (MEFP, Appendix Table I.3). Access and phasing are unchanged.

- New structural benchmarks are set for 2011 (Appendix Table I.2): (i) put in place a more effective VAT refund process (end-January); (ii) approve an increase in gas tariffs by 50 percent for all households and utility companies (effective April 15); (iii) gradually phase out NBU Resolution 109 to bring banks' foreign exchange positions more in line with international best practices (end-June); (iv) establish a framework to develop the forward exchange market (end-June); and (v) submit to parliament a 2012 budget consistent with a general government deficit of 2.5 percent of GDP (end-September). 


\section{Box 6. Ukraine: Stand-By Arrangement}

Access and length: SDR 10 billion over 29 months.

Phasing: SDR 1.25 billion (US\$1 billion for budget support) was purchased at approval on July 28, 2010. The second tranche of SDR 1 billion will be made available subject to completion of this review (US\$1 billion for budget support). The eight remaining tranches totaling SDR 7.75 billion are contingent upon completion of subsequent quarterly reviews, beginning in March 2011.

\section{Prior Actions}

- Submit to Parliament a 2011 budget consistent with a 3.1 percent of GDP deficit for the general government and the commitments in the MEFP, $₫ 6$.

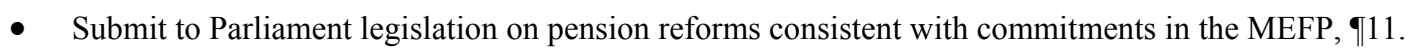

- Pass legislation to revoke the law "On temporary ban to levy penalties for overdue payments of utility bills" so that any arrears on utility payments will be subject to penalties (MEFP, $₫ 14$ ).

- $\quad$ NERC will issue (by December 16, 2010) instructions to communal utility companies to raise end-user heating tariffs (effective January 1, 2011) to reflect the August increases (MEFP, $₫ 15$ ).

\section{Quantitative and Continuous Performance Criteria}

- Floor on net international reserves.

- Ceiling on net domestic assets.

- Ceiling on the cash deficit of the general government.

- Ceiling on cash deficit of the general government and Naftogaz.

- Ceiling on publicly guaranteed debt.

- Non-accumulation of external debt payments arrears by the general government.

\section{Quantitative Indicative Targets}

- Ceiling on monetary base.

- Ceiling on VAT refund arrears.

\section{Structural Benchmarks}

- Parliamentary approval of legislation on pension reforms consistent with commitments in the MEFP, $\mathbb{1 1}$. By December 31, 2010.

- All banks should meet capital requirements and capital deficient banks should increase their capital in line with the approved plans (MEFP, $\mid 20$ ). By December 31, 2010.

- Complete due diligence of state-owned banks in line with the MEFP, $\uparrow 23$. By December 31, 2010.

- Initiate the implementation of the reform and restructuring strategy for Naftogaz in accordance with the principles of the Brussels Declaration. By December 31, 2010.

- Amend the law "On surcharges for the purposes of mandatory state pension insurance" to permanently eliminate the surcharge on non-cash purchases and sales of foreign currency (MEFP, $\llbracket 19$ ). By

December 31, 2010.

- Set up a more systematic, timely, and transparent VAT refund process. (MEFP 913 ). By January 31, 2011.

- Formulate a comprehensive public administration reform plan aiming to improve the cost efficiency of public service delivery (MEFP, ๆ12). By March 31, 2011.

- Approve an increase in gas tariffs for all households and utility companies by 50 percent, effective April 15 (MEFP, \15). By March 31, 2011.

- Adopt amendments to the Law of Ukraine "On restoring the solvency of the debtor or announcing him/her bankrupt" and related regulations to speed up the process, make it more transparent, and facilitate out-of-court restructuring (MEFP, $\uparrow 24)$. By June 30, 2011.

- Implement a schedule to phase out Resolution 109 with a gradual reduction of banks' foreign exchange positions in line with the MEFP, ฯ 19. By June 30, 2011.

- Establish a framework to develop the forward exchange market, including by allowing transactions between banks in line with the MEFP, $\uparrow 19$. By June 30, 2011.

- Submit to Parliament a 2012 budget consistent with a general government deficit of 2.5 percent of GDP. By September 30, 2011. 
23. The program remains fully financed, and Ukraine's capacity to repay the Fund is expected to be adequate. Higher capital inflows, including the recent Eurobond placement, helped offset financing shortfalls from official creditors in 2010. With delays in lending activities and the bulk of disbursements shifting to 2011, the World Bank, European Commission, EBRD, and EIB are now expected to provide about $\$ 1 \frac{1}{2}-2$ billion in 2011-12. Budget support from the EC and World Bank - accounting for the bulk of official financing in 2011 - is expected to resume during the first half of next year. Ukraine's strong political commitment to the program and improved access to private capital markets continue to provide assurances that it will fulfill its financial obligations to the Fund in a timely manner.

Government Financing by IFIs and Other Sources

\begin{tabular}{lrrr}
\multicolumn{4}{c}{ (Millions of U.S. dollars) } \\
\hline & 2010 & 2011 & 2012 \\
\hline Official financing & 448 & 1,817 & 1,250 \\
$\quad$ World Bank & 120 & 1,000 & 700 \\
European Commission & 147 & 680 & 486 \\
$\quad$ EBRD/EIB/Others & 181 & 136 & 64 \\
Eurobonds & 2,000 & 2,000 & 1,500 \\
Bank loan & 2,000 & 0 & 0 \\
Memorandum items: & & & \\
IMF financing & 3,464 & 6,083 & 2,308 \\
$\quad$ Purchases & 3,464 & 6,083 & 5,710 \\
$\quad$ Repurchases & 0 & 0 & 3,402 \\
\hline
\end{tabular}

Sources: National Bank of Ukraine; and IMF staff estimates.

\section{An updated safeguards assessment of the NBU was undertaken (MEFP |27). The} assessment found that the NBU has strengthened its safeguards framework since the 2008 assessment by implementing all of the related recommendations under its control. However, some specific resolutions and the deferment of some provisions under the new NBU law enacted in 2010 impair the NBU's autonomy. Specific recommendations under the updated assessment will be incorporated in the program at the time of the second review.

\section{StafF Appraisal}

25. The Ukrainian economy is steadily recovering, and the current juncture offers a window to push difficult reforms ahead. While macroeconomic risks are falling, they remain considerable. The challenge is to stay the course on policies agreed under the program, establish a strong record of policy implementation, and undertake other measures to improve the business environment and support private-sector led growth. 2011 is a key year in this regard, given the government's strong political position and no scheduled elections.

\section{Policies under the program remain on track. All end-September performance} criteria have been met, and the authorities are on track to meet the end-year targets. Satisfactory progress has also been made on structural reforms, with the completion of actions in the areas of the financial sector, foreign exchange market, and energy. Equally important, the authorities have put policies in place to meet the core program objectives and conditionality due in 2011.

\section{The underlying fiscal position is stabilizing, but more is needed to control debt} creating liabilities and place public debt firmly on a declining path. In 2010, expenditure control and revenue collection efforts have kept the budget deficit within targets during a difficult year where the revenue base was still unstable. The draft 2011 budget and Naftogaz's 2011 financial plan are set to deliver the adjustment envisaged under the program, based on a new tax code, current spending compression, and the initiation of structural 
reforms to address long standing fiscal rigidities. While there is pent-up demand for infrastructure spending, the authorities should strictly limit liabilities generated through state guaranteed loans, including for all Euro 2012-related construction. Already the recapitalization of state banks and Naftogaz, and the issuance of VAT bonds to clear the stock of arrears have added to public debt levels, and the recent Naftogaz-RUE settlement adds further pressure. Careful and transparent assessment and prioritization of projects, and strict control over state guarantees, will be key elements of the effort to reduce public debt.

\section{The authorities' overhaul of the tax and budget system deserves qualified}

support. After a new budget code was approved in the summer that introduced a mediumterm perspective for the budget, efforts turned to a new tax code that overhauls the taxation regime. The code is a testament to the authorities' fiscal goals: reducing the tax burden and the size of government over time. While it introduces several positive changes, its quality could have been better, and overall it was a missed opportunity to eliminate exemptions and simplify the tax system. Efforts should now focus on its fair and transparent administration.

\section{Spending adjustment backed by structural reforms is a priority. The expected}

submission of parametric pension reform legislation is a welcome first step and the authorities will need to promptly enact it - without diluting its objectives - to help achieve urgently needed stabilization of pension fund finances. An ambitious public administration reform to streamline public employment and improve the quality of public services is now under preparation. Structural reforms in the energy sector - including continued and significant energy price hikes to end-users - will also be needed. These together with a more forceful reduction of subsidies to SOEs, including Naftogaz, will be crucial to reduce the level of current spending in a durable way, and create the fiscal space the authorities need to be able to support higher infrastructure spending without jeopardizing fiscal objectives.

\section{The financial system is on the mend, but further efforts are needed to heal the} scars of the crisis. Capital buffers are being raised that should help banks withstand pressures if credit quality worsens further. The authorities are rightly focusing on addressing the NPLs problem, and forceful measures need to be developed in the months ahead to help banks deal effectively with bad loans. The faster the improvement in banks' balance sheets, the sooner they will be able to support credit growth, the absence of which is a drag on growth. Recently submitted legislation to parliament to strengthen bank supervision, once approved, will improve bank oversight and their ability to more carefully monitor risks. The authorities will also need to expedite their actions with respect to the three intervened banks.

\section{As the economy exits from the crisis, a more flexible exchange rate regime}

should be set in place. Monetary policy has aimed to balance inflation objectives within a weak credit environment. Going forward, monetary policy should be freed up to focus more squarely on bringing inflation down. A gradual shift to a more flexible exchange rate regime will better support Ukraine's objectives in this regard. The authorities are cautious in their efforts, concerned with jeopardizing the recently achieved stability. However, as confidence takes hold, the current regime should be gradually modified to allow banks more flexibility 
to manage exchange rate risks while maintaining incentives for the population to avoid taking excessive risks.

32. Continued adherence to prudent policies is essential to entrench macroeconomic stability and facilitate sustained growth. The program is off to a good start. The policies for the coming year, including the 2011 budget, pension reform, energy reforms, and bank rehabilitation reforms show the authorities' willingness to persevere with strengthening the Ukrainian economy and ability to make bold but important decisions. On the basis of these efforts, staff supports the authorities' request for completion of the first review. 
Figure 1. Ukraine: Real Sector Indicators, 2007-10

(Seasonally adjusted, quarter-on-quarter percent change, unless otherwise indicated)
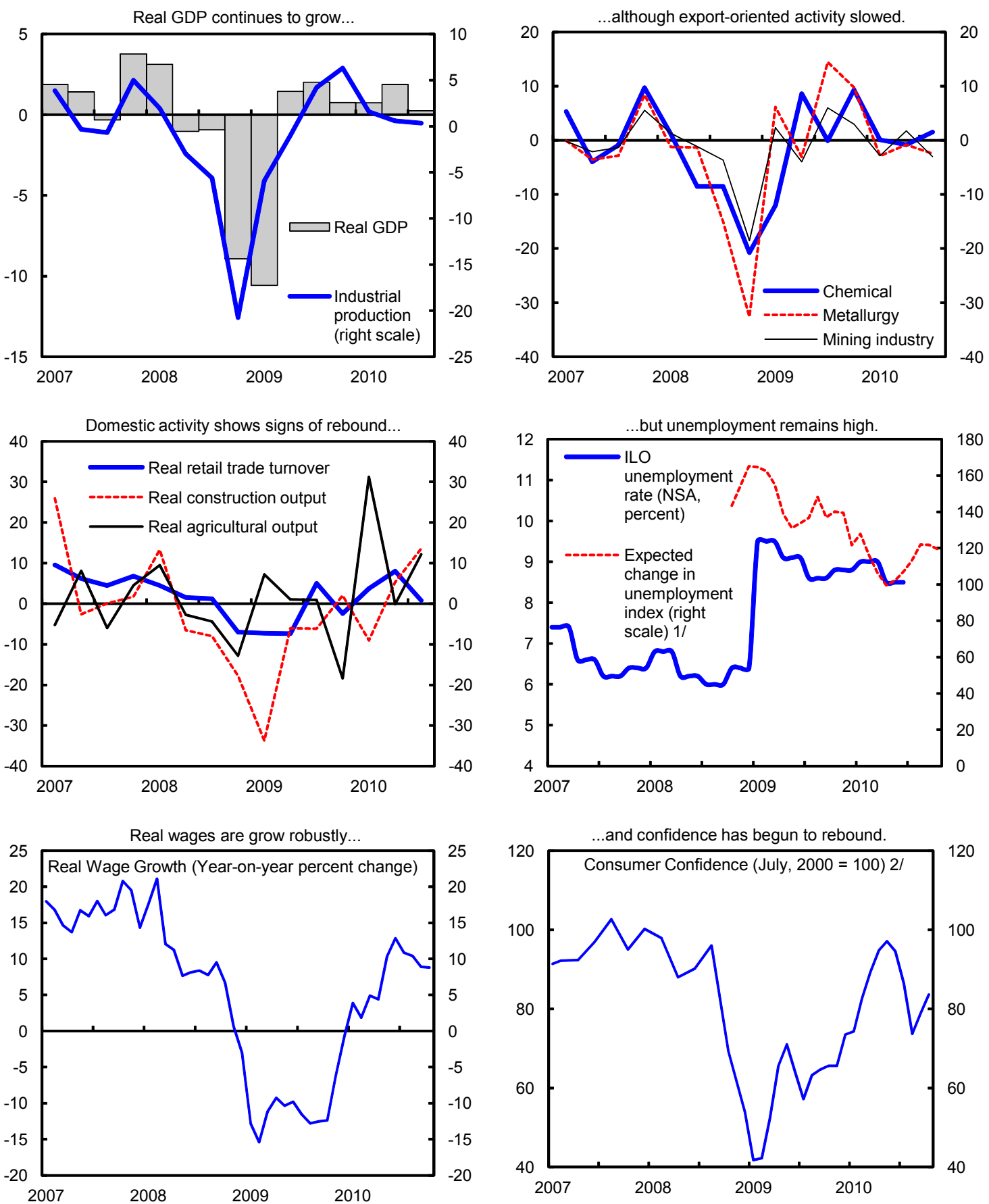

Sources: State Statistics Committee of Ukraine; Haver; International Centre for Policy Studies; and IMF staff calculations. $1 /$ Values above 100 indicate that more respondents expect unemployment to rise than fall over the next one to two months. Values can vary from 0 to 200.

2/ Consumer confidence index is based on survey respondents' answers to questions that relate to personal financial standing, changes in personal financial standing, economic conditions over the next year, economic conditions over the next five years, and propensity to consume. 
Figure 2. Ukraine: Performance Among Peers, 2002-11 1/
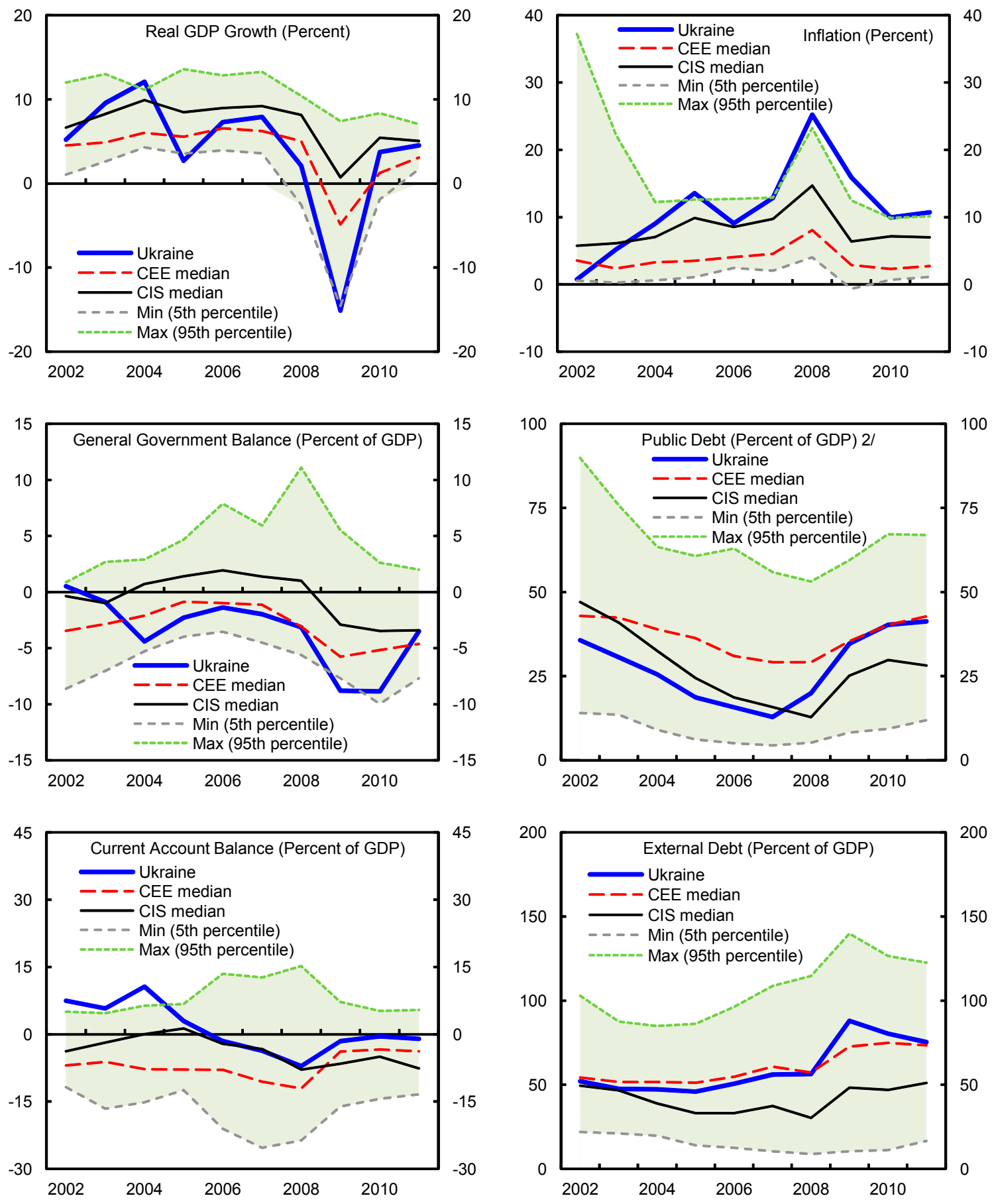

Sources: IMF, World Economic Outlook; and IMF staff calculations.

1/ CEE includes Albania, Bosnia and Herzegovina, Bulgaria, Croatia, Czech Rep., Estonia, Hungary, Latvia, Lithuania, Macedonia, Montenegro, Poland, Romania, Serbia, Slovak Rep., and Turkey . CIS includes Russia, Armenia, Azerbaijan, Belarus, Georgia, Kazakhstan, Kyrgyz Rep., Moldova, Mongolia, Tajikistan, Turkmenistan, and Uzbekistan. The 5th and 95th percentiles include the entire CEE and CIS samples excluding Ukraine.

2/ CIS, 5th, and 95th percentiles exclude Mongolia. 
Figure 3. Ukraine: Inflation, Monetary, and Exchange Rate Developments, 2007-10 (Year-on-year percent change, unless otherwise indicated)

Headline inflation peaked in August-September...
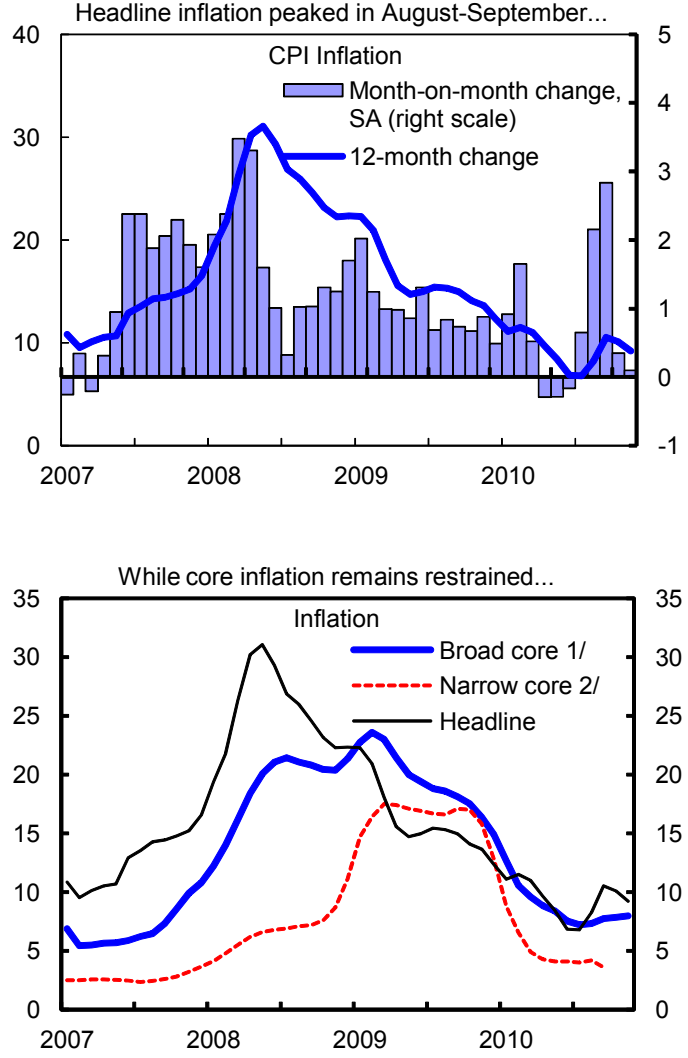

The NBU's reserves have increased substantially...

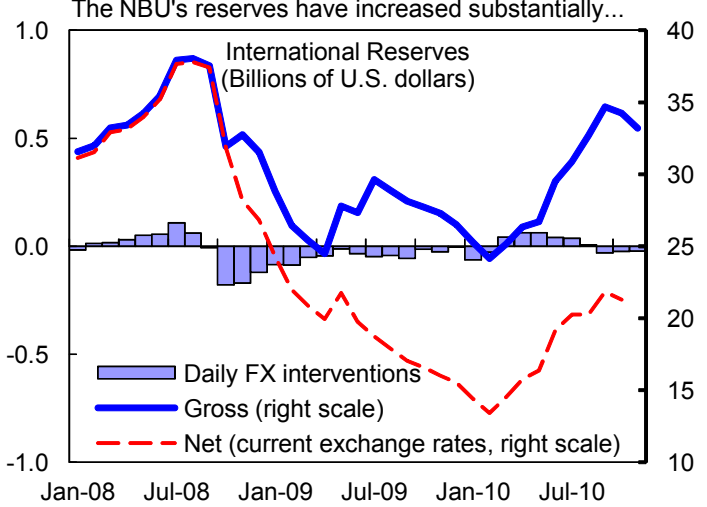

...but slowed more recently on the back of moderating food prices.
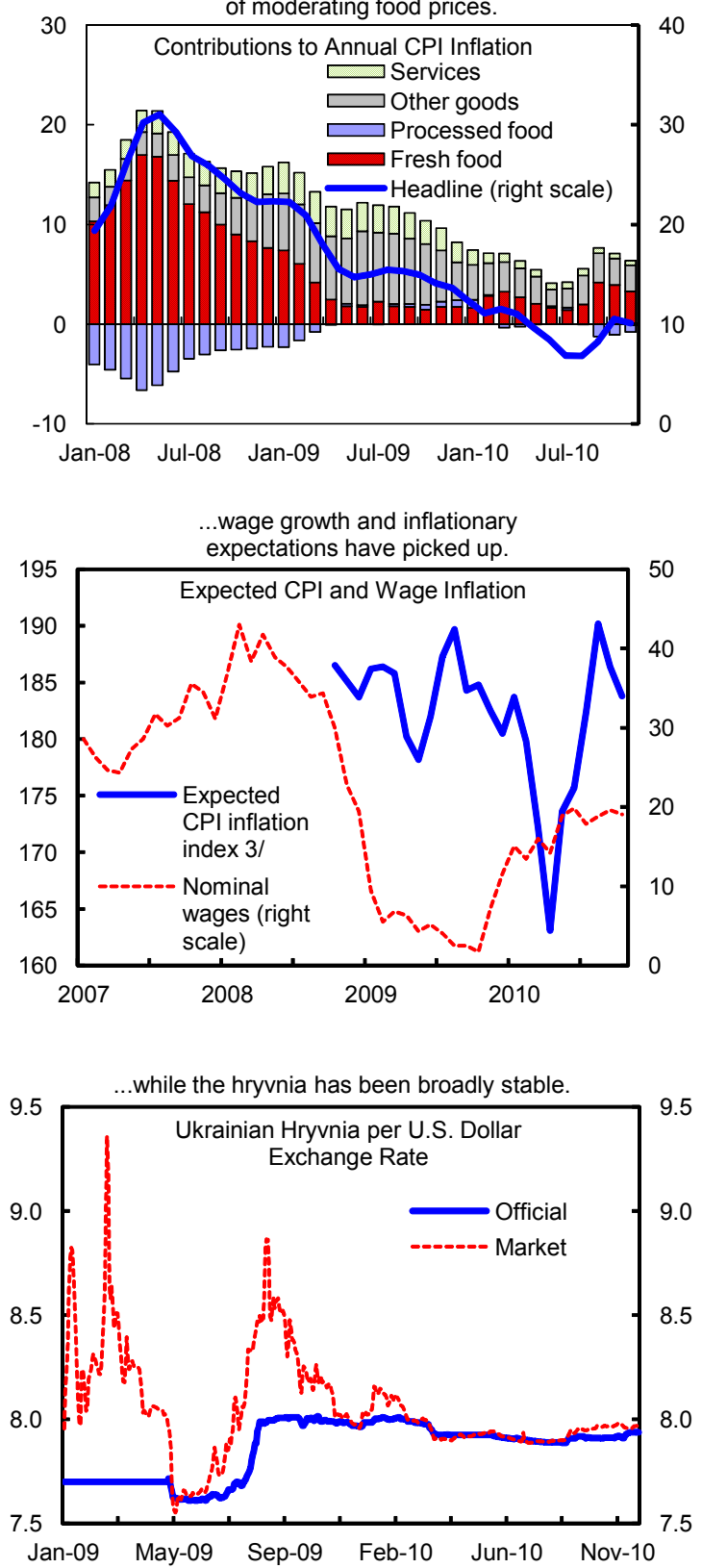

Sources: State Statistics Committee of Ukraine; International Centre for Policy Studies; National Bank of Ukraine; Bloomberg; and IMF staff calculations.

$1 /$ Broad core excludes unprocessed food, fuel, and administrative services.

2/ Narrow core excludes food, fuel, and all services.

$3 /$ Values above 100 indicate that more respondents expect inflation to rise than to fall over the next one to two months.

Values can vary from 0 to 200 . 
Figure 4. Ukraine: External Sector Developments, 2008-10

(Billions of U.S. dollars)
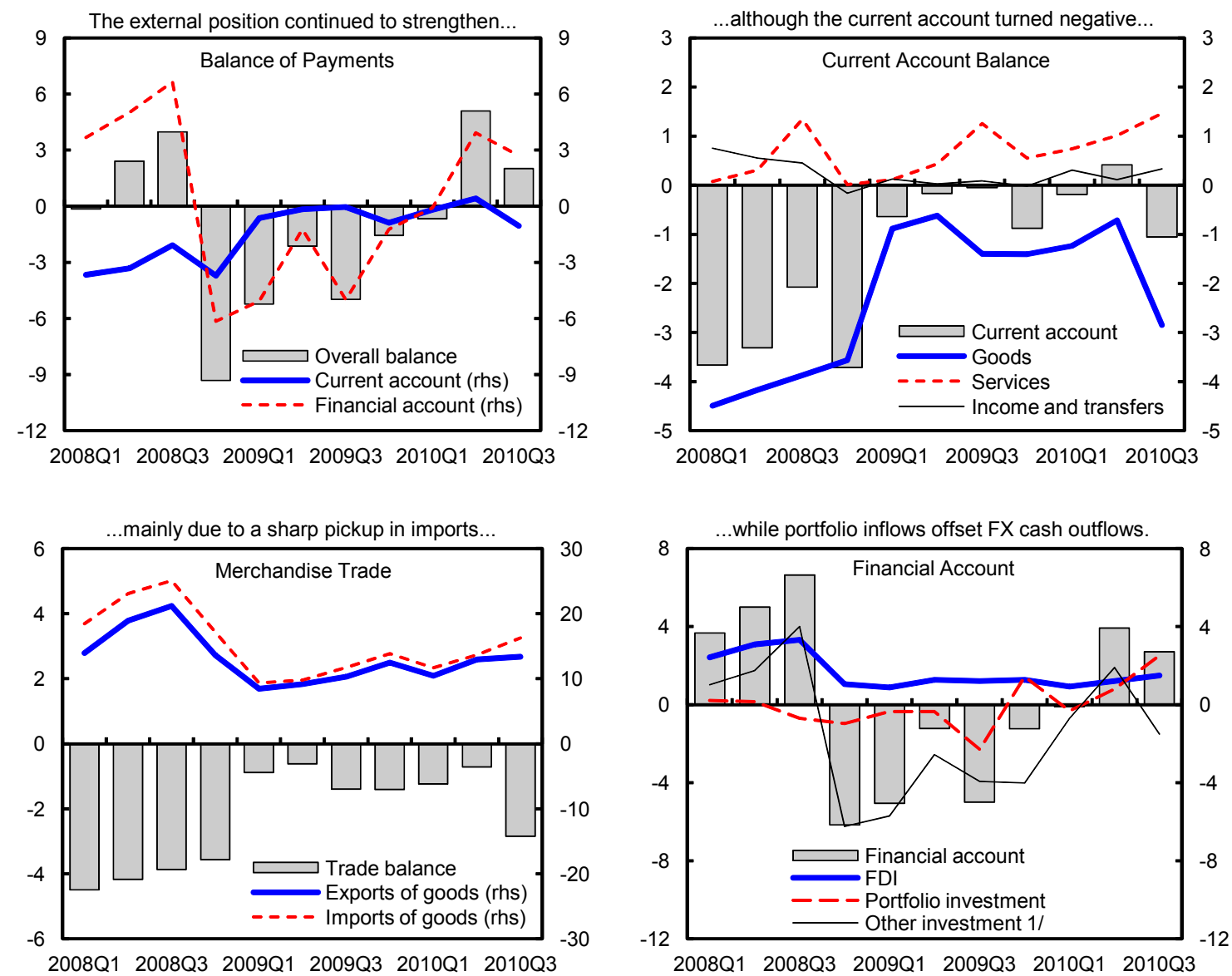

Sources: National Bank of Ukraine; State Committee of Statistics; and IMF staff estimates and calculations. 1/ Excludes IMF resources. 
Figure 5. Ukraine: Financial Sector Indicators, 2008-10

(Billions of Ukrainian hryvnias, unless otherwise indicated)
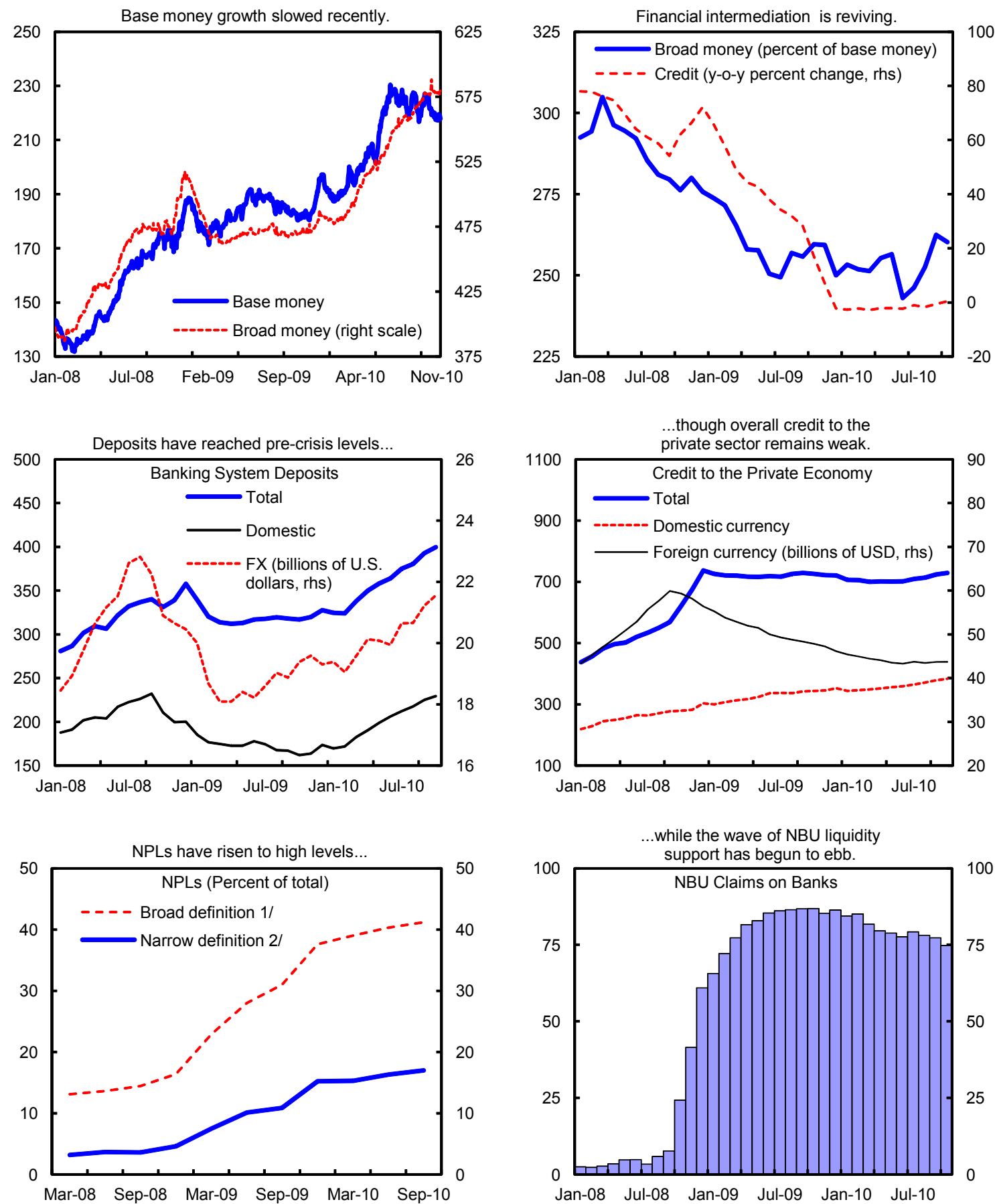

Sources: National Bank of Ukraine; and IMF staff calculations.

$1 /$ Includes NPLs that are classified as substandard, doubtful, and loss.

2/ Excludes substandard loans serviced in a timely manner. 
Figure 6. Ukraine: Public Debt Sustainability: Bound Tests 1/ (Public debt in percent of GDP)
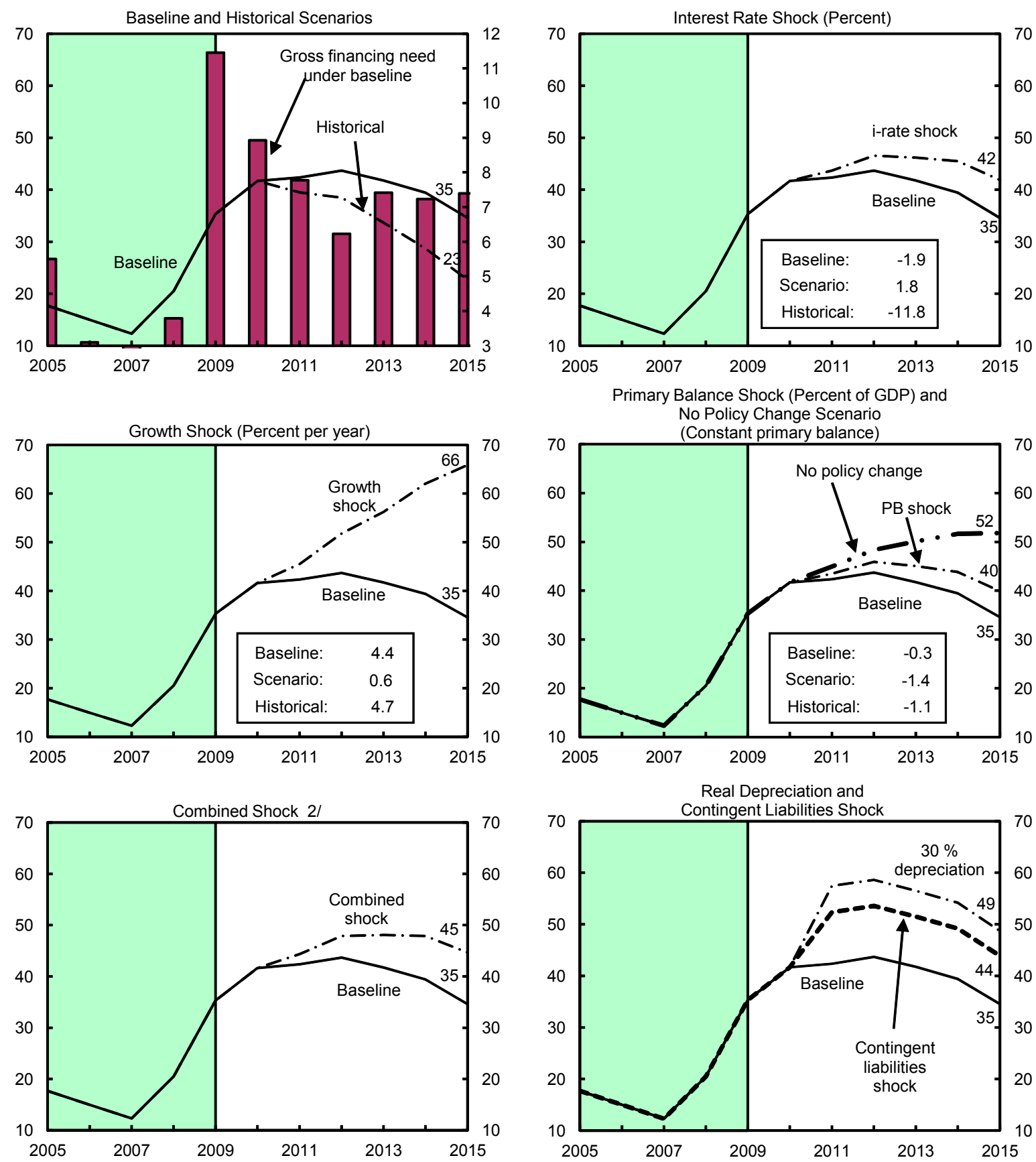

Sources: IMF staff estimates.

1/ Shaded areas represent actual data. Individual shocks are permanent one-half standard deviation shocks. Figures in the boxes represent average projections for the respective variables in the baseline and scenario being presented. Ten-year historical average for the variable is also shown.

2/ Permanent $1 / 4$ standard deviation shocks applied to real interest rate, growth rate, and primary balance.

$3 /$ One-time real depreciation of 30 percent and 10 percent of GDP shock to contingent liabilities occur in 2009, with real depreciation defined as nominal depreciation (measured by percentage fall in dollar value of local currency) minus domestic inflation 
Figure 7. Ukraine: External Debt Sustainability: Bound Tests 1/ (External debt in percent of GDP)
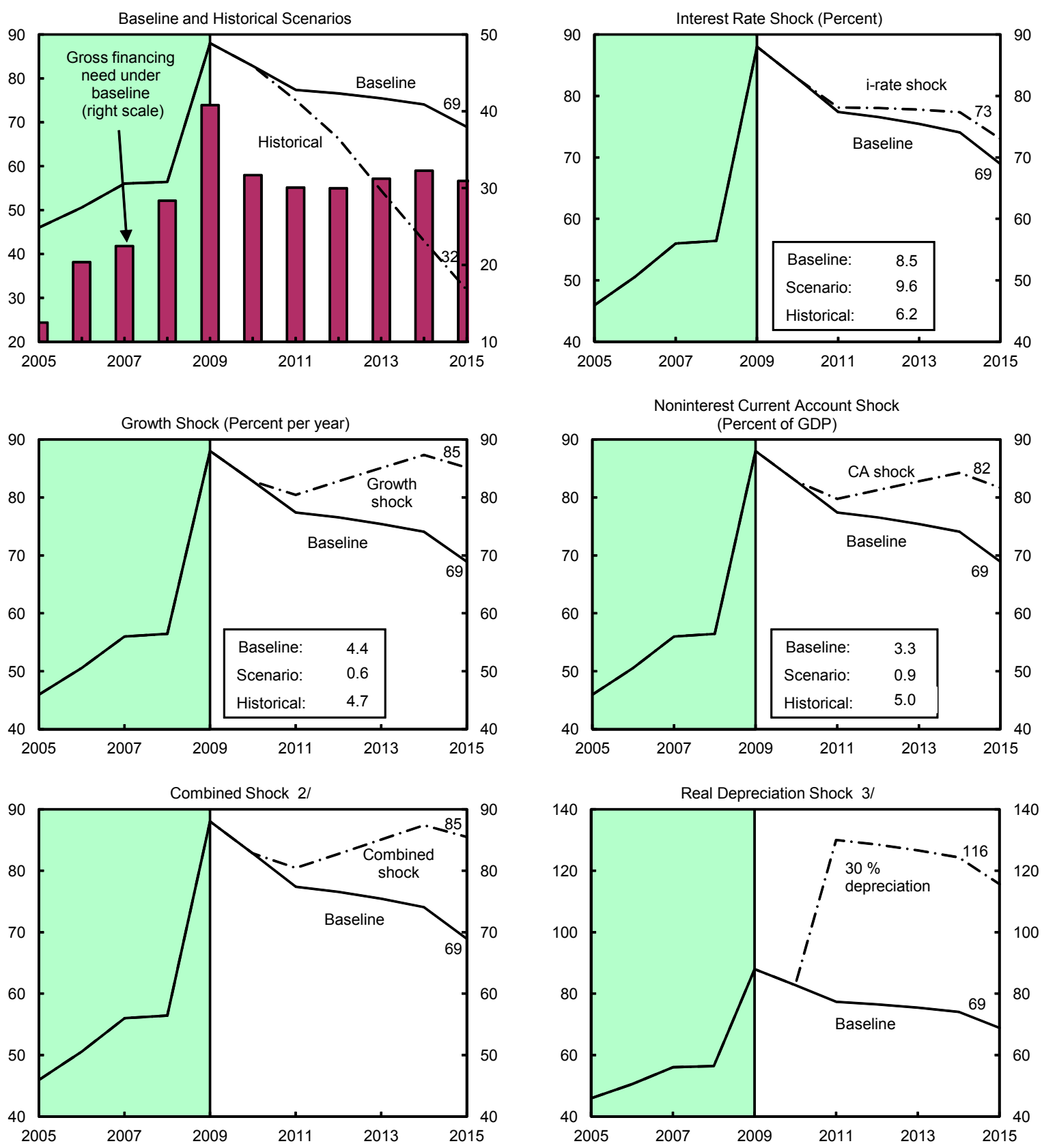

Sources: IMF staff estimates.

$1 /$ Shaded areas represent actual data. Individual shocks are permanent one-half standard deviation shocks. Figures in the boxes represent average projections for the respective variables in the baseline and scenario being presented. Ten-year historical average for the variable is also shown.

2/ Permanent 1/4 standard deviation shocks applied to real interest rate, growth rate, and current account balance.

$3 /$ In line with standard IMF stress tests, the shock simulates the impact of a one-time real depreciation of 30 percent in 2010. 
Table 1. Ukraine: Selected Economic and Social Indicators, 2007-12

\begin{tabular}{|c|c|c|c|c|c|c|c|}
\hline & \multirow[t]{2}{*}{2007} & \multirow[t]{2}{*}{2008} & \multirow[t]{2}{*}{2009} & \multirow{2}{*}{$\begin{array}{c}2010 \\
\text { Program }\end{array}$} & 2010 & 2011 & 2012 \\
\hline & & & & & \multicolumn{3}{|c|}{ Proj. } \\
\hline \multicolumn{8}{|l|}{ Real economy (percent change, unless otherwise indicated) } \\
\hline Nominal GDP (billions of Ukrainian hrynnias) & 721 & 948 & 915 & 1,083 & 1,083 & 1,253 & 1,431 \\
\hline Real GDP & 7.9 & 2.1 & -15.1 & 3.7 & 3.7 & 4.5 & 4.9 \\
\hline \multicolumn{8}{|l|}{ Contributions: } \\
\hline Domestic demand & 16.0 & 7.9 & -25.6 & 4.9 & 6.3 & 5.8 & B.1 \\
\hline Consumption & 9.4 & 6.3 & -10.1 & 1.4 & 3.2 & 2.8 & 3.2 \\
\hline Investment & 6.6 & 1.7 & -15.5 & 3.4 & 3.0 & 3.0 & 2.9 \\
\hline Net exports & -8.1 & -5.8 & 10.5 & -1.1 & -2.5 & -1.3 & -1.2 \\
\hline Unemployment rate (ILO definition; percent) & 6.4 & 6.4 & 8.8 & 8.8 & 8.8 & 7.8 & 7.2 \\
\hline Consumer prices (period average) & 12.8 & 25.2 & 15.9 & 9.9 & 9.9 & 10.6 & 9.3 \\
\hline Consumer prices (end of period) & 16.6 & 22.3 & 12.3 & 12.0 & 12.0 & 9.8 & 8.3 \\
\hline Core inflation (period average) $1 /$ & 7.1 & 19.0 & 19.4 & $\ldots$ & 8.6 & 7.3 & 5.7 \\
\hline Core inflation (end of period) $1 /$ & 10.8 & 21.3 & 14.9 & $\ldots$ & 8.1 & 5.9 & 5.5 \\
\hline Nominal monthly wages (average) & 29.7 & 33.7 & 5.5 & 16.0 & 16.0 & 12.8 & 11.8 \\
\hline Real monthly wages (average) & 14.8 & 6.8 & -8.9 & 5.5 & 5.5 & 2.0 & 2.3 \\
\hline \multicolumn{8}{|l|}{ Public finance (percent of GDP) } \\
\hline General government balance $2 /$ & -2.0 & -3.2 & -6.3 & -5.5 & -5.1 & -3.1 & -2.5 \\
\hline Net domestic financing & $\ldots$ & 2.8 & 1.6 & 2.8 & 1.1 & 2.4 & 1.3 \\
\hline Of which: privatization proceeds & $\ldots$ & 0.3 & 0.2 & 0.9 & 0.2 & 0.8 & 0.3 \\
\hline Net external financing & $\ldots$ & 0.4 & 4.7 & 2.7 & 4.1 & 0.8 & 1.2 \\
\hline Overall balance (including Naftogaz operational deficit) & $\ldots$ & -3.2 & -8.7 & -6.5 & -6.5 & -3.5 & -2.5 \\
\hline Overall balance (including Naftogaz, and other flows) $3 /$ & $\ldots$ & -3.2 & -11.3 & -9.9 & -9.9 & -3.5 & -2.5 \\
\hline Public debt (end of period) $4 /$ & 12.3 & 20.5 & 35.3 & 39.5 & 41.7 & 42.4 & 43.7 \\
\hline Of which: external debt (foreign currency denominated) & 9.8 & 15.8 & 25.3 & $\ldots$ & 24.8 & 26.1 & 28.7 \\
\hline \multicolumn{8}{|l|}{ Money and credit (end of period, percent change) } \\
\hline Base money & 46.0 & 31.6 & 4.4 & 14.4 & 14.4 & 13.5 & 13.3 \\
\hline Broad money & 51.7 & 30.2 & -5.5 & 14.7 & 17.9 & 15.1 & 13.6 \\
\hline Credit to nongovernment & 74.0 & 71.9 & -2.2 & 4.0 & 3.7 & 7.5 & 11.4 \\
\hline Velocity & 1.8 & 1.8 & 1.9 & 1.9 & 1.9 & 1.9 & 1.9 \\
\hline Interbank overnight rate (annual average, percent) 5 / & 2.3 & 13.7 & 12.6 & 1.3 & 3.7 & $\ldots$ & $\ldots$ \\
\hline \multicolumn{8}{|l|}{ Balance of payments (percent of GDP) } \\
\hline Current account balance & -3.7 & -7.1 & -1.5 & -0.7 & -2.0 & -2.4 & -2.6 \\
\hline Foreign direct investment & 6.5 & 5.5 & 4.0 & 3.4 & 3.6 & 3.6 & 3.7 \\
\hline Gross reserves (end of period, billions of U.S. dollars) & 32.5 & 31.5 & 26.5 & 30.3 & 32.4 & 39.0 & 45.4 \\
\hline Months of next year's imports of goods and services & 3.8 & 6.7 & 4.4 & 4.8 & 4.8 & 5.3 & 5.6 \\
\hline Percent of short-term debt (remaining maturity) & 84.8 & 68.3 & 65.5 & 74.8 & 74.2 & 83.8 & 91.7 \\
\hline External debt (percent of GDP) & 56.0 & 56.4 & 88.0 & 79.0 & 82.8 & 77.4 & 76.5 \\
\hline Goods exports (annual volume change in percent) & 3.2 & 1.1 & -25.5 & 9.0 & 9.0 & 7.4 & 6.8 \\
\hline Goods imports (annual volume change in percent) & 20.3 & 13.5 & -42.5 & 10.7 & 16.5 & 9.5 & 8.0 \\
\hline Goods terms of trade (percent change) & 9.0 & 10.0 & -13.8 & 1.9 & 2.4 & 1.5 & 0.9 \\
\hline \multicolumn{8}{|l|}{ Exchange rate } \\
\hline Hryvnia per U.S. dollar, end of period $5 /$ & 5.1 & 7.7 & 8.0 & $\ldots$ & 8.0 & $\ldots$ & $\ldots$ \\
\hline Hryvnia per U.S. dollar, period average 5/ & 5.1 & 5.3 & 7.8 & $\ldots$ & 8.0 & $\ldots$ & $\ldots$ \\
\hline Real effective rate (CPI, percent change) $6 /$ & 2.5 & 10.3 & -17.6 & $\cdots$ & 9.0 & $\cdots$ & $\cdots$ \\
\hline \multicolumn{8}{|l|}{ Memorandum items: } \\
\hline Nominal GDP (billions of U.S. dollars) & 142.7 & 180.1 & 117.4 & $\cdots$ & $\ldots$ & $\ldots$ & $\ldots$ \\
\hline Per capita GDP (2009): $\$ 2,569$ (WEO) & & & \multicolumn{5}{|c|}{ Percent of population below poverty line (2006): 8.0} \\
\hline Quota (2009): SDR 1,372 million (2,168 million U.S. dollars) & & & & & & & \\
\hline
\end{tabular}

Sources: State Statistics Committee of Ukraine; Ministry of Finance; National Bank of Ukraine; World Bank, World Development Indicators; and IMF staff estimates and projections.

$1 /$ Excludes unprocessed food, fuel, and administrative services.

$2 /$ The general government includes the central and local governments and the social funds.

$3 /$ Other debt creating flows include bonds issued to (i) recapitalize banks in 2009-11, and (ii) settle arrears on VAT refunds in 2010.

4 / Government and government-guaranteed debt (includes debt to IMF).

5/ Latest data as of end-November 2010.

6. Latest data as of end-Octoker 2010. 
Table 2. Ukraine: General Government Finances, 2008-12

(Billions of Ukrainian hryvnia)

\begin{tabular}{|c|c|c|c|c|c|c|}
\hline & \multirow[t]{2}{*}{2008} & \multirow[t]{2}{*}{2009} & \multirow{2}{*}{$\begin{array}{r}2010 \\
\text { Program }\end{array}$} & 2010 & 2011 & 2012 \\
\hline & & & & \multicolumn{3}{|c|}{ Proj. } \\
\hline Revenue & 419.7 & 386.3 & 463.3 & 468.8 & 520.9 & 584.6 \\
\hline Tax revenue & 358.1 & 337.4 & 412.3 & 407.4 & 464.6 & 523.8 \\
\hline Tax on income, profits, and capital gains & 93.8 & 77.5 & 94.6 & 94.9 & 103.2 & 113.4 \\
\hline Personal income tax & 45.9 & 44.5 & 50.5 & 50.5 & 58.2 & 65.0 \\
\hline Corporate profit tax & 47.9 & 33.0 & 44.1 & 44.4 & 45.0 & 48.4 \\
\hline Payroll tax & 107.9 & 110.8 & 126.7 & 122.5 & 141.1 & 157.5 \\
\hline Property tax & 6.7 & 8.4 & 9.4 & 9.6 & 11.0 & 12.0 \\
\hline Tax on goods and services & 132.1 & 125.8 & 133.3 & 144.7 & 159.7 & 185.5 \\
\hline VAT & 92.1 & 84.6 & 97.8 & 102.0 & 108.3 & 127.5 \\
\hline Excise & 13.0 & 21.6 & 33.5 & 30.4 & 41.5 & 47.5 \\
\hline Other & 27.0 & 19.5 & 2.0 & 12.3 & 9.9 & 10.5 \\
\hline Tax on international trade & 12.3 & 6.9 & 8.8 & 8.8 & 9.8 & 11.6 \\
\hline Other tax & 5.4 & 8.0 & 39.5 & 26.9 & 39.8 & 43.8 \\
\hline Nontax revenue & 61.6 & 48.9 & 51.1 & 61.4 & 56.3 & 60.8 \\
\hline Expenditure & 449.6 & 443.5 & 522.9 & 524.3 & 560.2 & 620.4 \\
\hline Current & 392.5 & 420.5 & 491.1 & 494.5 & 520.9 & 579.0 \\
\hline Compensation of employees & 97.7 & 106.0 & 131.4 & 131.1 & 134.8 & 147.0 \\
\hline Goods and services & 59.5 & 67.6 & 67.5 & 78.0 & 84.2 & 96.1 \\
\hline Interest & 4.9 & 10.6 & 16.0 & 15.7 & 24.3 & 30.4 \\
\hline Subsidies to corporations and enterprises & 34.4 & 27.2 & 24.5 & 21.3 & 17.6 & 17.6 \\
\hline Social benefits & 196.0 & 209.1 & 251.4 & 248.2 & 259.7 & 287.6 \\
\hline Social programs (on budget) & 36.6 & 26.3 & 38.1 & 37.1 & 39.7 & 47.2 \\
\hline Pensions & 143.8 & 165.8 & 194.5 & 192.3 & 199.1 & 217.6 \\
\hline Unemployment, disability, and accident insurance & 15.6 & 16.9 & 18.8 & 18.8 & 20.9 & 22.8 \\
\hline Other transfers & 0.0 & 0.1 & 0.2 & 0.2 & 0.3 & 0.3 \\
\hline Capital & 52.9 & 20.0 & 29.1 & 27.1 & 37.1 & 39.1 \\
\hline Net lending & 2.8 & 2.8 & 1.2 & 1.2 & 0.7 & 0.8 \\
\hline Discrepancy / reserve fund & 1.4 & 0.1 & 1.5 & 1.5 & 1.5 & 1.5 \\
\hline Overall balance & -30.0 & -57.1 & -59.6 & -55.5 & -39.3 & -35.8 \\
\hline Primary balance & -25.0 & -46.5 & -43.6 & -39.9 & -15.0 & -5.4 \\
\hline General government financing & 30.0 & 57.1 & 59.6 & 55.6 & 39.3 & 35.8 \\
\hline Extemal & 3.6 & 42.7 & 29.6 & 44.0 & 9.5 & 17.3 \\
\hline Disbursements & 6.2 & 58.4 & 52.1 & 50.5 & 34.2 & 31.3 \\
\hline Of which: IMF (includes SDR allocations) & 0.0 & 11.6 & 16.0 & 16.0 & 0.0 & 0.0 \\
\hline Amortizations & -2.6 & -15.7 & -22.5 & -6.5 & -24.7 & -14.0 \\
\hline Domestic (net) & 26.4 & 14.4 & 30.0 & 11.6 & 29.8 & 18.5 \\
\hline Bond financing & 20.0 & 6.6 & 18.4 & 25.2 & 9.8 & 10.5 \\
\hline Direct bank borrowing & 0.0 & 0.0 & 0.0 & 0.0 & 0.0 & 0.0 \\
\hline Deposit finance & 3.9 & 5.7 & 1.6 & -15.3 & 10.0 & 3.0 \\
\hline Privatization & 2.5 & 2.1 & 10.0 & 1.7 & 10.0 & 5.0 \\
\hline Naftogaz financing & $\ldots$ & 22.7 & 11.0 & 15.0 & 5.1 & 0.0 \\
\hline General government and Naftogaz financing & 30.0 & 79.8 & 70.6 & 70.6 & 44.4 & 35.8 \\
\hline Other financing & 0.0 & 23.3 & 36.4 & 36.4 & 0.0 & 0.0 \\
\hline Bank recapitalization 1/ & 0.0 & 23.3 & 20.0 & 20.0 & 0.0 & 0.0 \\
\hline VAT bonds & 0.0 & 0.0 & 16.4 & 16.4 & 0.0 & 0.0 \\
\hline Total financing & 30.0 & 103.1 & 107.0 & 106.9 & 44.4 & 35.8 \\
\hline
\end{tabular}


Table 2. Ukraine: General Government Finances, 2008-12 (concluded)

(Percent of GDP, unless otherwise indicated)

\begin{tabular}{|c|c|c|c|c|c|c|}
\hline & 2008 & 2009 & 2010 & 2010 & 2011 & 2012 \\
\hline & \multicolumn{4}{|c|}{ Program } & \multicolumn{2}{|c|}{ Proj. } \\
\hline Revenue & 44.3 & 42.2 & 42.8 & 43.3 & 41.6 & 40.8 \\
\hline Tax revenue & 37.8 & 36.9 & 38.1 & 37.6 & 37.1 & 36.6 \\
\hline Tax on income, profits, and capital gains & 8.9 & 8.5 & 8.7 & 8.8 & 8.2 & 7.9 \\
\hline Personal income tax & 4.8 & 4.9 & 4.7 & 4.7 & 4.6 & 4.5 \\
\hline Corporate profit tax & 5.0 & 3.6 & 4.1 & 4.1 & 3.6 & 3.4 \\
\hline Payroll tax & 11.4 & 12.1 & 11.7 & 11.3 & 11.3 & 11.0 \\
\hline Property tax & 0.7 & 0.9 & 0.9 & 0.9 & 0.9 & 0.8 \\
\hline Tax on goods and services & 13.9 & 13.7 & 12.3 & 13.4 & 12.7 & 13.0 \\
\hline VAT & 9.7 & 9.2 & 9.0 & 9.4 & 8.6 & 8.9 \\
\hline Excise & 1.4 & 2.4 & 3.1 & 2.8 & 3.3 & 3.3 \\
\hline Other & 2.8 & 2.1 & 0.2 & 1.1 & 0.8 & 0.7 \\
\hline Tax on international trade & 1.3 & 0.8 & 0.8 & 0.8 & 0.8 & 0.8 \\
\hline Other tax & 0.6 & 0.9 & 3.6 & 2.5 & 3.2 & 3.1 \\
\hline Nontax revenue & 6.5 & 5.3 & 4.7 & 5.7 & 4.5 & 4.2 \\
\hline Expenditure & 47.4 & 48.5 & 48.3 & 48.4 & 44.7 & 43.4 \\
\hline Current & 41.4 & 46.0 & 45.4 & 45.7 & 41.6 & 40.5 \\
\hline Compensation of employees & 10.3 & 11.6 & 12.1 & 12.1 & 10.8 & 10.3 \\
\hline Goods and services & 6.3 & 7.4 & 6.2 & 7.2 & 6.7 & 6.7 \\
\hline Interest & 0.5 & 1.2 & 1.5 & 1.4 & 1.9 & 2.1 \\
\hline Subsidies to corporations and enterprises & 3.6 & 3.0 & 2.3 & 2.0 & 1.4 & 1.2 \\
\hline Social benefits & 20.7 & 22.9 & 23.2 & 22.9 & 20.7 & 20.1 \\
\hline Social programs (on budget) & 3.9 & 2.9 & 3.5 & 3.4 & 3.2 & 3.3 \\
\hline Pensions & 15.2 & 18.1 & 18.0 & 17.8 & 15.9 & 15.2 \\
\hline Unemployment, disability, and accident insurance & 1.6 & 1.9 & 1.7 & 1.7 & 1.7 & 1.6 \\
\hline Other transfers & 0.0 & 0.0 & 0.0 & 0.0 & 0.0 & 0.0 \\
\hline Capital & 5.6 & 2.2 & 2.7 & 2.5 & 3.0 & 2.7 \\
\hline Net lending & 0.3 & 0.3 & 0.1 & 0.1 & 0.1 & 0.1 \\
\hline Discrepancy / reserve fund & 0.1 & 0.0 & 0.1 & 0.1 & 0.1 & 0.1 \\
\hline Overall balance & -3.2 & -6.2 & -5.5 & -5.1 & -3.1 & -2.5 \\
\hline Primary balance & -2.6 & -5.1 & -4.0 & -3.7 & -1.2 & -0.4 \\
\hline General government financing & 3.2 & 6.2 & 5.5 & 5.1 & 3.1 & 2.5 \\
\hline External & 0.4 & 4.7 & 2.7 & 4.1 & 0.8 & 1.2 \\
\hline Disbursements & 0.7 & 6.4 & 4.8 & 4.7 & 2.7 & 2.2 \\
\hline Of which: IMF (includes SDR allocations) & 0.0 & 1.3 & 1.5 & 1.5 & 0.0 & 0.0 \\
\hline Amortizations & -0.3 & -1.7 & -2.1 & -0.6 & -2.0 & -1.0 \\
\hline Domestic (net) & 2.8 & 1.6 & 2.8 & 1.1 & 2.4 & 1.3 \\
\hline Bond financing & 2.1 & 0.7 & 1.7 & 2.3 & 0.8 & 0.7 \\
\hline Direct bank borrowing & 0.0 & 0.0 & 0.0 & 0.0 & 0.0 & 0.0 \\
\hline Deposit finance & 0.4 & 0.6 & 0.1 & -1.4 & 0.8 & 0.2 \\
\hline Privatization & 0.3 & 0.2 & 0.9 & 0.2 & 0.8 & 0.3 \\
\hline Naftogaz financing & $\ldots$ & 2.5 & 1.0 & 1.4 & 0.4 & 0.0 \\
\hline General government and Naftogaz financing & 3.2 & 8.7 & 6.5 & 6.5 & 3.5 & 2.5 \\
\hline Other financing & 0.0 & 2.5 & 3.4 & 3.4 & 0.0 & 0.0 \\
\hline Bank recapitalization $1 /$ & 0.0 & 2.5 & 1.8 & 1.8 & 0.0 & 0.0 \\
\hline VAT bonds & 0.0 & 0.0 & 1.5 & 1.5 & 0.0 & 0.0 \\
\hline Total financing & 3.2 & 11.3 & 9.9 & 9.9 & 3.5 & 2.5 \\
\hline \multicolumn{7}{|l|}{ Memorandum items } \\
\hline Cyclically-adjusted primary balance & -9.2 & -2.8 & $\ldots$ & -2.1 & -1.1 & -1.4 \\
\hline Nominal GDP (billions of Ukrainian hryvnia) & 948 & 915 & 1,083 & 1,083 & 1,253 & 1,431 \\
\hline
\end{tabular}

Sources: Ministry of Finance; National Bank of Ukraine; and IMF staff estimates and projections.

1/ Amounts budgeted for but not used in 2010 may be carried into 2011. 
Table 3. Ukraine: Gross Financing Requirements for General Government, 2010-11

(Billions of Ukrainian hryvnias)

\begin{tabular}{lrr}
\hline & 2010 & 2011 \\
\cline { 2 - 3 } & \multicolumn{2}{c}{ Proj. } \\
\hline Uses & $\mathbf{8 1 . 7}$ & $\mathbf{9 2 . 8}$ \\
Deficit & 55.5 & 39.3 \\
Amortizations & 26.1 & 53.5 \\
$\quad$ External & 6.5 & 24.7 \\
$\quad$ Domestic & 19.6 & 28.8 \\
Sources & $\mathbf{8 1 . 7}$ & $\mathbf{9 2 . 8}$ \\
Domestic financing & 31.2 & 58.6 \\
Deposits & -15.3 & 10.0 \\
Domestic securities and loans & 44.8 & 38.6 \\
Privatization & 1.7 & 10.0 \\
External financing & 50.5 & 34.2 \\
Eurobond & 15.8 & 15.9 \\
VTB bank & 15.8 & 0.0 \\
IFls (including net project financing) & 18.8 & 18.3 \\
Other public sector financing: & & \\
VAT bonds & 16.4 & 0.0 \\
Bank recapitalization 1/ & 20.0 & 0.0 \\
Naftogaz deficit financing & 15.0 & 0.0 \\
\hline
\end{tabular}

Sources: Ukrainian authorities; and IMF staff projections.

$1 /$ Amounts budgeted for but not used in 2010 may be carried into 2011. 
Table 4. Ukraine: Balance of Payments, 2007-12

(Billions of U.S. dollars, unless otherwise indicated)

\begin{tabular}{|c|c|c|c|c|c|c|c|}
\hline \multirow{3}{*}{ Current account balance } & \multirow{3}{*}{$\begin{array}{r}2007 \\
-5.3\end{array}$} & \multirow{3}{*}{$\begin{array}{r}2008 \\
-12.8\end{array}$} & \multirow{3}{*}{$\begin{array}{r}2009 \\
-1.7\end{array}$} & \multirow{2}{*}{$\begin{array}{c}2010 \\
\text { Program }\end{array}$} & \multirow{2}{*}{\multicolumn{2}{|c|}{$\begin{array}{ll}2010 & 2011 \\
& \text { Proj. }\end{array}$}} & \multirow[t]{2}{*}{2012} \\
\hline & & & & & & & \\
\hline & & & & -1.0 & -2.8 & -3.8 & -4.5 \\
\hline Merchandise trade balance & -10.6 & -16.1 & -4.3 & -5.5 & -7.6 & -9.0 & -10.1 \\
\hline Exports, f.o.b. & 49.8 & 67.7 & 40.4 & 48.5 & 51.7 & 58.0 & 64.4 \\
\hline Imports, f.o.b. & -60.4 & -83.8 & -44.7 & -54.0 & -59.3 & -66.9 & -74.4 \\
\hline Services (net) & 2.4 & 1.7 & 2.4 & 4.1 & 4.0 & 4.6 & 4.9 \\
\hline Receipts & 14.2 & 17.9 & 13.9 & 16.7 & 16.6 & 18.0 & 19.3 \\
\hline Payments & -11.7 & -16.2 & -11.5 & -12.7 & -12.6 & -13.4 & -14.4 \\
\hline Income (net) & -0.7 & -1.5 & -2.4 & -2.4 & -2.1 & -2.5 & -2.6 \\
\hline Current transfers (net) & 3.5 & 3.1 & 2.7 & 2.8 & 3.0 & 3.1 & 3.3 \\
\hline Capital and financial account balance & 15.1 & 9.2 & -12.3 & -0.1 & 4.2 & 2.5 & 7.3 \\
\hline Capital account $1 /$ & 0.0 & 0.0 & 0.6 & 0.0 & 0.2 & 0.0 & 0.0 \\
\hline Financial account & 15.1 & 9.2 & -12.9 & -0.1 & 4.0 & 2.5 & 7.3 \\
\hline Direct investment (net) & 9.2 & 9.9 & 4.7 & 4.6 & 4.9 & 5.7 & 6.3 \\
\hline Portfolio investment (net) & 5.8 & -1.3 & -1.6 & 1.5 & 3.7 & 2.1 & 2.2 \\
\hline Other investment (net) & 0.2 & 0.5 & -16.0 & -6.1 & -4.5 & -5.3 & -1.2 \\
\hline Medium and long-term loans & 14.4 & 14.8 & -3.3 & -2.6 & 0.0 & -1.2 & 2.1 \\
\hline Official & 0.5 & 0.5 & 0.2 & -0.4 & 1.5 & -2.0 & 0.6 \\
\hline Disbursements $2 /$ & 1.2 & 0.9 & 0.7 & 2.0 & 1.8 & 0.5 & 1.0 \\
\hline Repayments & -0.8 & -0.5 & -0.5 & -2.5 & -0.3 & -2.5 & -0.4 \\
\hline Banks & 6.6 & 8.1 & -1.9 & -1.5 & -1.8 & 0.3 & 0.8 \\
\hline Other sectors & 7.3 & 6.2 & -1.6 & -0.6 & 0.3 & 0.5 & 0.7 \\
\hline Short-term loans & -0.6 & -3.0 & -1.5 & 1.4 & 4.5 & 0.8 & 1.0 \\
\hline Banks & 4.1 & -1.8 & -4.7 & 0.3 & 0.2 & 0.1 & 0.3 \\
\hline Other sectors $3 /$ & -4.6 & -1.2 & 3.2 & 1.1 & 4.4 & 0.7 & 0.7 \\
\hline Currency and deposits & -13.7 & -11.3 & -11.3 & -5.0 & -9.0 & -4.9 & -4.2 \\
\hline Banks & -0.1 & 1.6 & -1.6 & -1.0 & -2.0 & 0.1 & 0.3 \\
\hline Other sectors $4 /$ & -13.6 & -12.9 & -9.7 & -4.0 & -7.0 & -5.0 & -4.5 \\
\hline Errors and omissions & -0.4 & 0.5 & 0.2 & -0.3 & 0.7 & 0.0 & 0.0 \\
\hline Overall balance & 9.4 & -3.1 & -13.9 & -1.3 & 2.2 & -12 & 2.8 \\
\hline Prospective official financing & $\ldots$ & $\ldots$ & $\ldots$ & 1.6 & 0.4 & 1.8 & 1.2 \\
\hline World Bank & $\ldots$ & $\ldots$ & $\cdots$ & 0.5 & 0.1 & 1.0 & 0.7 \\
\hline EU & $\ldots$ & $\ldots$ & $\ldots$ & 0.5 & 0.1 & 0.7 & 0.5 \\
\hline EBRD/Others & $\ldots$ & $\ldots$ & $\ldots$ & 0.6 & 0.2 & 0.1 & 0.1 \\
\hline Financing & -9.4 & 3.1 & 13.9 & -0.2 & -2.6 & -0.6 & -4.0 \\
\hline Gross official reserves (increase: -) & -9.0 & -1.1 & 5.7 & -3.6 & -6.1 & -6.7 & -6.4 \\
\hline Not uoo of IMF rooourvoo $6 /$ & -0.4 & 4.1 & 8.2 & 3.3 & 3.6 & 0.1 & 2.3 \\
\hline \multicolumn{8}{|l|}{ Memorandum items: } \\
\hline Total external debt & 80.0 & 101.7 & 103.3 & 107.6 & 112.9 & 122.0 & 130.3 \\
\hline Total external debt (percent of GDP) & 56.0 & 56.4 & 88.0 & 79.0 & 82.8 & 77.4 & 76.5 \\
\hline Current account balance (percent of GDP) & -3.7 & -7.1 & -1.5 & -0.7 & -2.0 & -2.4 & -2.6 \\
\hline Excluding transfers & -6.2 & -8.8 & -3.7 & -2.8 & -4.3 & -4.4 & -4.6 \\
\hline Gross international reserves (end of period) & 32.5 & 31.5 & 26.5 & 30.3 & 32.4 & 39.0 & 45.4 \\
\hline Months of next year's imports of goods and services & 3.9 & 6.7 & 4.4 & 4.8 & 4.8 & 5.3 & 5.6 \\
\hline Percent of shart-term debt (remaining maturity) & 84.8 & 68.3 & 65.5 & 74.8 & 74.2 & 83.8 & 91.7 \\
\hline Merchandise export value (percent change) & 28.0 & 35.9 & -40.3 & 20.1 & 27.9 & 12.2 & 11.0 \\
\hline Merchandise import value (percent change) & 36.9 & 38.7 & -46.7 & 19.9 & 32.6 & 12.9 & 11.2 \\
\hline Merchandise export volume (percent change) & 3.2 & 1.1 & -25.5 & 9.0 & 9.0 & 7.4 & 6.8 \\
\hline Merchandise import volume (percent change) & 20.3 & 13.5 & -42.5 & 10.7 & 16.5 & 9.5 & 8.0 \\
\hline Goods terms of trade (percent change) & 9.0 & 10.0 & -13.8 & 1.9 & 2.4 & 1.5 & 0.9 \\
\hline
\end{tabular}

Sources: National Bank of Ukraine; and IMF staff estimates and projections.

1/ Primarily reflects sale of greenhouse gas emission quotas in 2009-10.

2/ For program period (2010-12), prospective financing from official sources is recorded below the line. Includes bilateral loans for government-guaranteed energy project.

$3 /$ Includes trade credit and arrears.

4/ Mainly reflects residents' conversion of hryvnia cash to foreign currency with the banking system.

5/ Includes the general and speclal allocattons of SDR 1,309.4 mlllon (about US\$2 billlon) In August and September 2009. 
Table 5. Ukraine: Gross External Financing Requirements, 2009-12

(Billions of U.S. dollars)

\begin{tabular}{|c|c|c|c|c|}
\hline & 2009 & 2010 & 2011 & 2012 \\
\hline & & \multicolumn{3}{|c|}{ Proj. } \\
\hline Total financing requirements & 44.7 & 35.5 & 35.4 & 32.9 \\
\hline Current account deficit & 1.7 & 2.8 & 3.8 & 4.5 \\
\hline Medium and long-term debt & 18.5 & 15.2 & 17.6 & 14.9 \\
\hline Private & 16.4 & 13.6 & 14.5 & 14.0 \\
\hline Public (including bonds) & 2.1 & 1.6 & 3.1 & 0.9 \\
\hline Short-term debt (including deposits) & 13.2 & 10.0 & 9.1 & 9.1 \\
\hline Other net capital outflows $1 /$ & 11.2 & 7.6 & 5.0 & 4.5 \\
\hline Total financing sources & 30.6 & 37.0 & 34.1 & 35.7 \\
\hline Capital transfers 2/ & 0.6 & 0.2 & 0.0 & 0.0 \\
\hline Direct investment, net & 4.7 & 4.9 & 5.7 & 6.3 \\
\hline Portfolio investment & 0.0 & 4.9 & 2.7 & 2.6 \\
\hline Medium and long-term loans & 14.0 & 13.7 & 15.7 & 16.5 \\
\hline Private & 13.3 & 11.9 & 15.2 & 15.5 \\
\hline Public 3/ & 0.7 & 1.8 & 0.5 & 1.0 \\
\hline Short-term loans (including deposits) & 9.4 & 11.3 & 9.5 & 9.8 \\
\hline Trade credit, net & 2.0 & 2.0 & 0.5 & 0.5 \\
\hline Increase in gross reserves & -5.7 & 6.1 & 6.7 & 6.4 \\
\hline Errors and omissions & 0.2 & 0.7 & 0.0 & 0.0 \\
\hline Financing gap & 8.2 & 3.9 & 7.9 & 3.6 \\
\hline Prospective official financing & 8.2 & 3.9 & 7.9 & 3.6 \\
\hline IMF & 8.2 & 3.5 & 6.1 & 2.3 \\
\hline Purchases 4/ & 8.3 & 3.5 & 6.1 & 5.7 \\
\hline Repurchases & 0.1 & 0.0 & 0.0 & 3.4 \\
\hline Official creditors & $\ldots$ & 0.4 & 1.8 & 1.2 \\
\hline World Bank & $\ldots$ & 0.1 & 1.0 & 0.7 \\
\hline EU & $\ldots$ & 0.1 & 0.7 & 0.5 \\
\hline EBRD/Others & $\ldots$ & 0.2 & 0.1 & 0.1 \\
\hline \multicolumn{5}{|l|}{ Memorandum item: } \\
\hline Gross international reserves & 26.5 & 32.4 & 39.0 & 45.4 \\
\hline
\end{tabular}

Sources: National Bank of Ukraine; and IMF staff estimates and projections.

$1 /$ Mainly reflects residents' conversion of hryvnia cash to foreign currency with the banking system.

2/ Primarily reflects sale of greenhouse gas emission quotas in 2009-10.

3/ For program period (2010-12), prospective financing from official sources is recorded below the line. Includes bilateral loans for government-guaranteed energy project.

4/ Includes the general and special allocations of SDR 1,309.4 million (about \$2 billion U.S. dollars) in August and September 2009. 
Table 6. Ukraine: Monetary Accounts, 2010-11

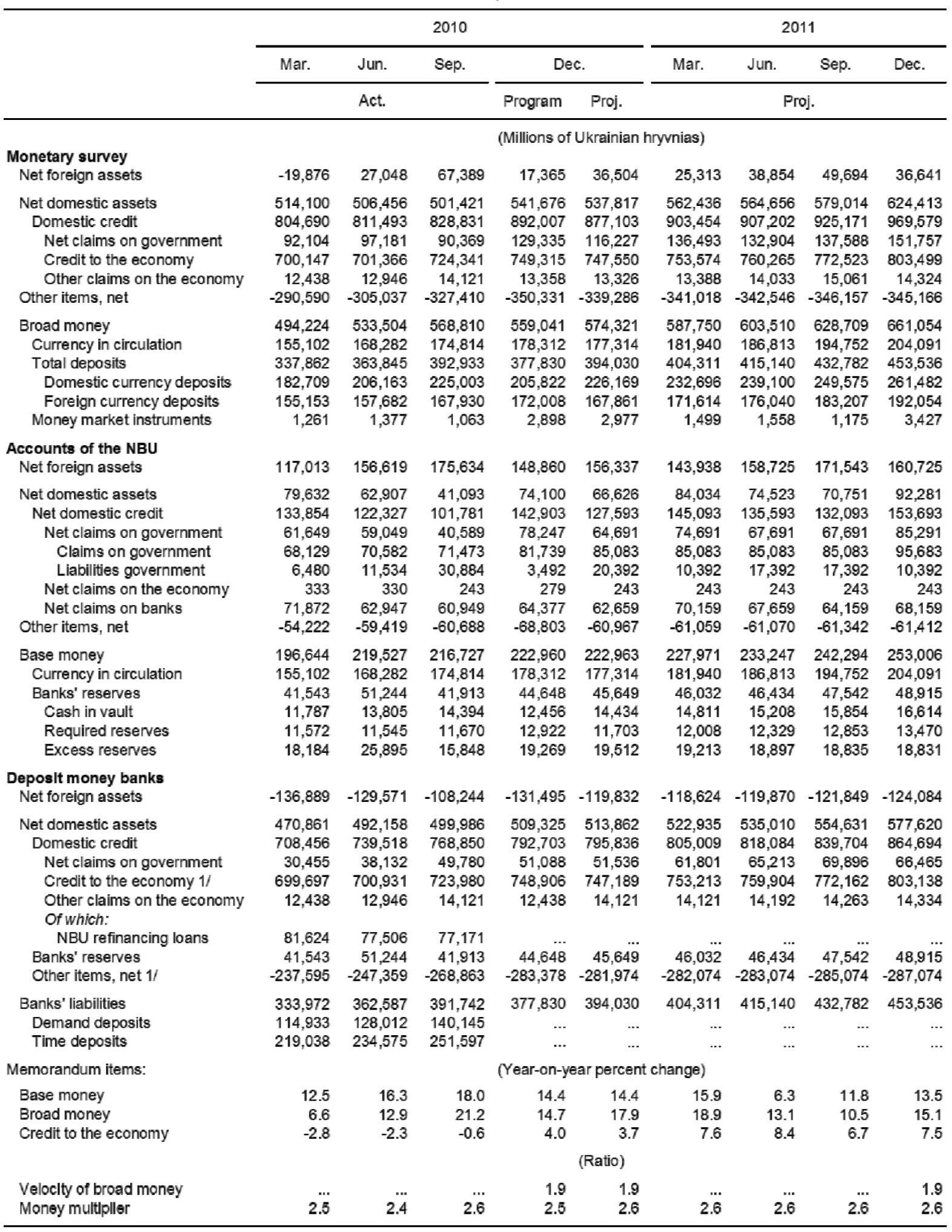

Sources: National Bank of Ukraine; and IMF staff estimates and projections.

$1 /$ Projections do not reflect possible writedowns of nonperforming losns. 
Table 7. Medium-term Macroeconomic Framework, 2007-15

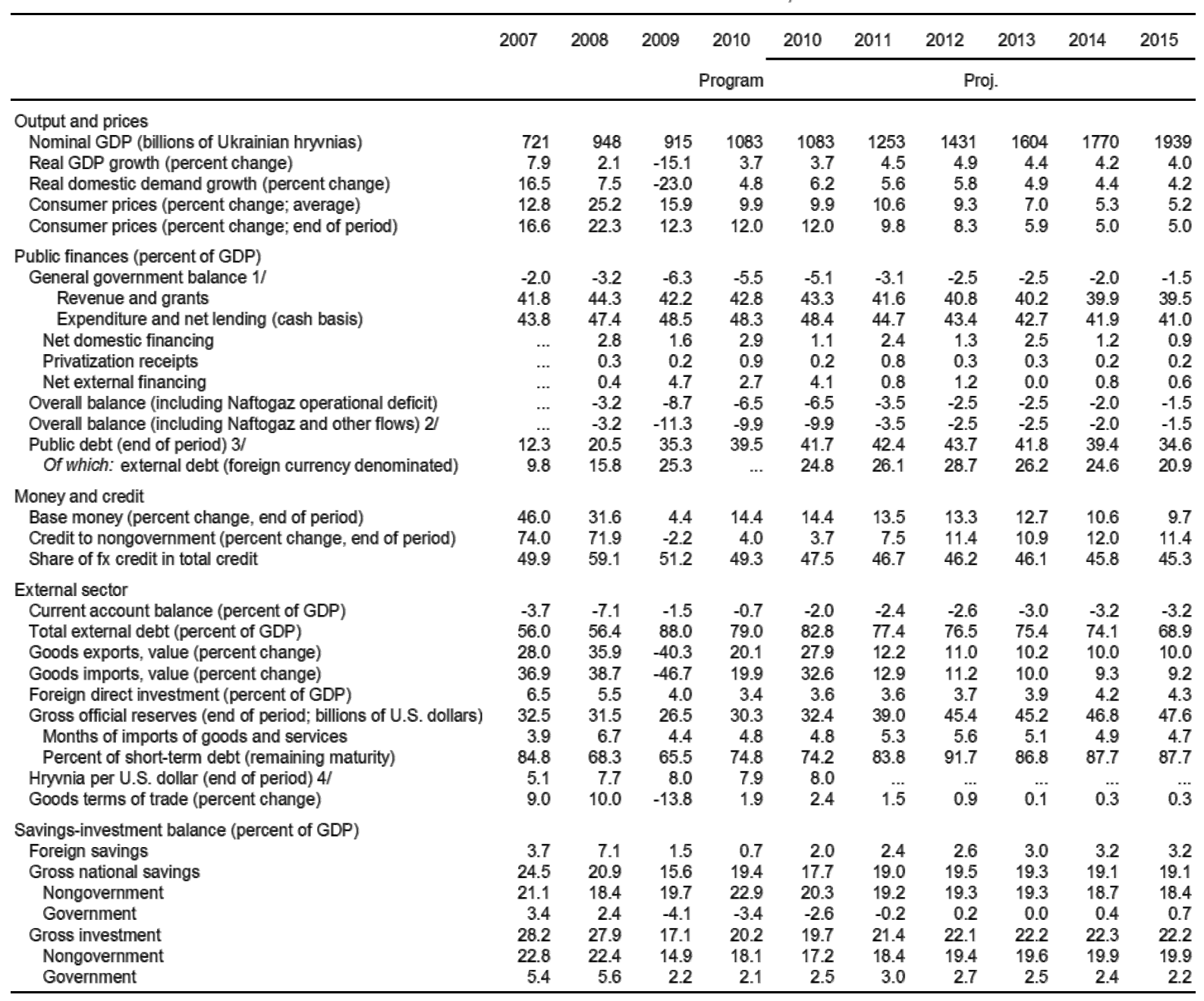

Sources: State Statistics Committee of Ukraine; Ministry of Finance; National Bank of Ukraine; World Bank, World Development indicators ; and IMF staff estimates and projections.

1/ The general government includes the central and local governments and the social funds

$2 /$ Other debt creating flows include bonds issued to recapitalize banks in 2009-11, and bonds issued to settle arrears on VAT refunds in 2010.

3/ Government and government-guaranteed debt (includes all IMF debt).

4/ Latest data as of end-November 2010. 
Table 8. Ukraine: Financial Soundness Indicators for the Banking Sector, 2006-10

(Percent, unless otherwise indicated)

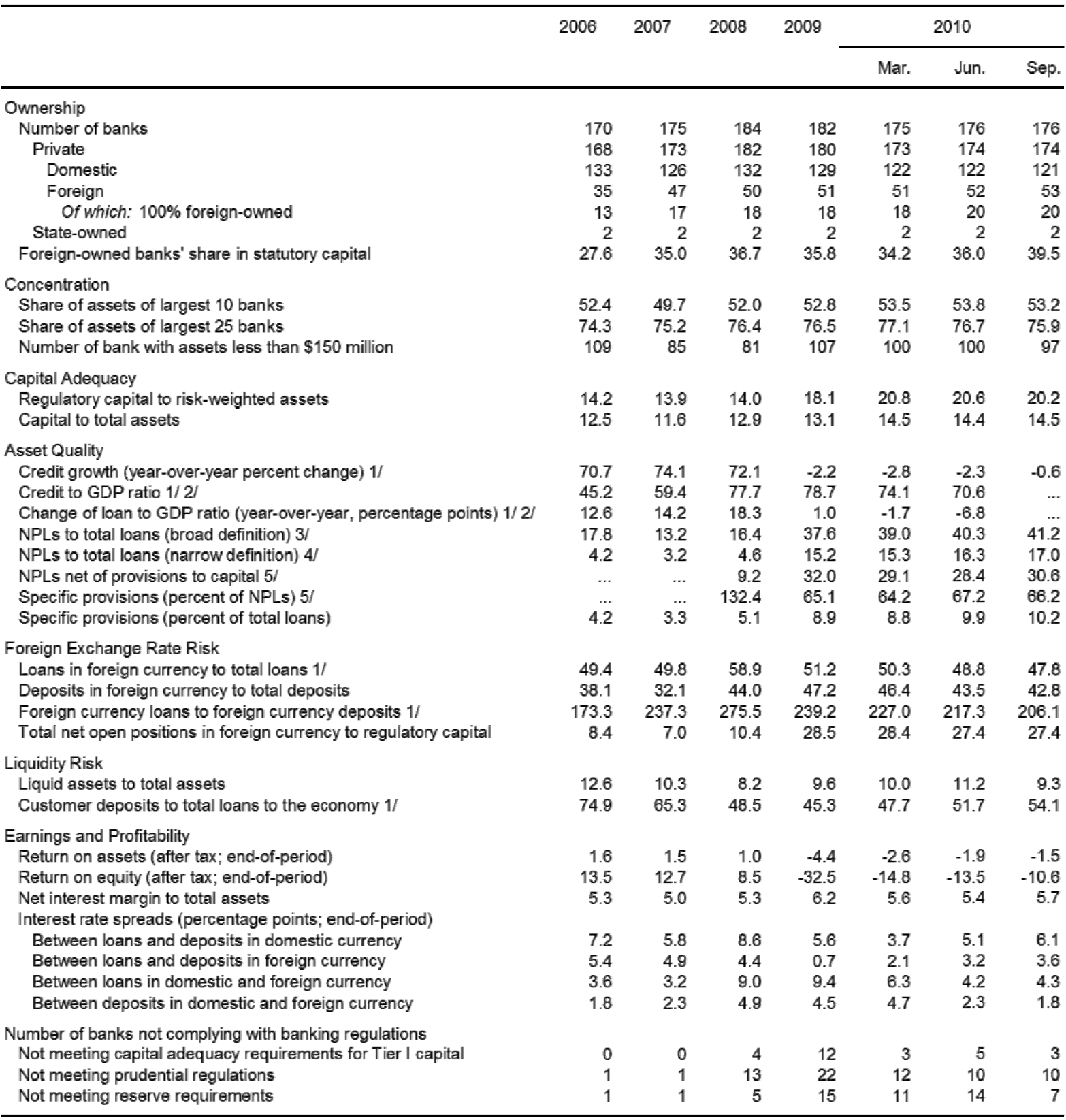

Sources: National Bank of Ukraine; and IMF staff estimates.

$1 /$ Monetary statistics data.

2/ Calculated using a moving average of GDP for the previous four quarters.

$3 /$ Includes NPLs that are classified as substandard, doubtful, and loss. However, this broad definition may not be comparable to other countries as, in addition to servicing status, loan classification also depends on borrower's financial conditions and collateralization level.

4/ Excludes substandard loans serviced in a timely manner.

$5 /$ Nonperforming loans include doubtful and loss loans in compliance with IMF's Methodology for the Compilation of FSIs. NBU data since 2008. 
Table 9. Ukraine: Selected Vulnerability Indicators, 2006-10

\begin{tabular}{|c|c|c|c|c|c|c|}
\hline & 2006 & 2007 & 2008 & 2009 & 2010 & $\begin{array}{r}\text { Latest } \\
\text { observation }\end{array}$ \\
\hline \multicolumn{7}{|l|}{ Financial market indicators } \\
\hline Short-term interest rate (percent) $1 /$ & 3.6 & 2.3 & 13.7 & 12.6 & 2.2 & 26-Nov-10 \\
\hline EMBI secondary market spread (basis points, end of period) & 172 & 303 & 2,771 & 989 & 526 & 26-Nov-10 \\
\hline Foreign currency debt rating $2 /$ & BB- & BB- & $B+$ & B- & B & $6-J u l-10$ \\
\hline Exchange rate (hryvnia per U.S. dollar, end of period) & 5.1 & 5.1 & 7.7 & 8.0 & 7.9 & 26-Nov-10 \\
\hline Stock market index (PFTS) & 498.9 & $1,174.0$ & 301.4 & 572.9 & 829.9 & 26-Nov-10 \\
\hline Broad money to gross reserves (percent) & 232.3 & 241.6 & 212.3 & 230.2 & 218.7 & 26-Nov-10 \\
\hline \multicolumn{7}{|l|}{ External sector } \\
\hline Current account balance (percent of GDP) & -1.5 & -3.7 & -7.1 & -1.5 & -2.0 & Proj. \\
\hline Capital and financial account balance (percent of GDP) & 3.7 & 10.6 & 5.1 & -10.5 & 3.4 & Proj. \\
\hline Net FDI inflows (percent of GDP) & 5.3 & 6.5 & 5.5 & 4.0 & 3.6 & Proj. \\
\hline $\begin{array}{l}\text { Exports of goods and nonfactor services (percent change of } \\
\text { U.S. dollar value) }\end{array}$ & 13.2 & 27.4 & 33.8 & -36.6 & 25.7 & Proj. \\
\hline Real effective exchange rate (percent change) $3 /$ & 4.7 & 2.5 & 10.3 & -17.6 & 9.0 & Oct-10 \\
\hline Gross international reserves (billions of U.S. dollars) & 22.3 & 32.5 & 31.5 & 26.5 & 32.4 & Proj. \\
\hline Months of next year's imports of goods and services & 3.7 & 3.9 & 6.7 & 4.4 & 4.8 & Proj. \\
\hline Percent of short-term debt at remaining maturity & 83.0 & 84.8 & 68.3 & 65.5 & 74.2 & Proj. \\
\hline Net international reserves (billions of U.S. dollars) & 21.4 & 32.0 & 26.9 & 15.5 & 18.3 & Proj. \\
\hline Total external debt (percent of GDP) & 50.6 & 56.0 & 56.4 & 88.0 & 82.8 & Proj. \\
\hline $\begin{array}{l}\text { Of which: short-term external debt (original maturity, } \\
\text { percent of total external debt) }\end{array}$ & 27.9 & 25.9 & 20.0 & 18.4 & 20.4 & Proj. \\
\hline $\begin{array}{l}\text { External debt of domestic private sector (percent of total } \\
\text { external debt) }\end{array}$ & 78.3 & 84.6 & 83.6 & 76.8 & 72.7 & Proj. \\
\hline \multicolumn{7}{|l|}{ General government } \\
\hline $\begin{array}{l}\text { Overall balance (including Naftogaz, and other debt creating } \\
\text { flows) }\end{array}$ & $\ldots$ & $\ldots$ & -3.2 & -11.3 & -9.9 & Proj. \\
\hline Primary balance (percent of GDP) & -0.7 & -1.5 & -2.6 & -5.1 & -3.7 & Proj. \\
\hline $\begin{array}{l}\text { Gross financing requirement } \\
\text { (percent of GDP) } 4 /\end{array}$ & $\ldots$ & $\ldots$ & 3.8 & 14.0 & 12.3 & פ. \\
\hline Gross debt (percent of GDP) & 14.8 & 12.3 & 20.5 & 35.3 & 41.7 & Proj. \\
\hline
\end{tabular}

Sources: Bloomberg; National Bank of Ukraine; Ministry of Finance; and IMF staff estimates and projections.

$1 /$ Overnight interbank rate. Monthly average for December or month of latest observation.

2/ Fitch long-term FX debt rating. Latest observation refers to last rating change.

3/ Period averages; (+) represents real appreciation; based on CPI and INS trade weights (2004-06).

4 / Overall balance plus debt amortization. 
Table 10. Ukraine: Indicators of Fund Credit, 2008-15

\begin{tabular}{|c|c|c|c|c|c|c|c|c|}
\hline & 2008 & 2009 & 2010 & 2011 & 2012 & 2013 & 2014 & 2015 \\
\hline & & & \multicolumn{6}{|c|}{ Proj. } \\
\hline \multicolumn{9}{|c|}{ Stock of existing and prospective Fund credit $1 / 2 /$} \\
\hline Millions of SDRs & 3,057 & 7,000 & 9,250 & 13,250 & 14,766 & 11,109 & 7,969 & 4,250 \\
\hline Percent of quota & 223 & 510 & 674 & 966 & 1,076 & 810 & 581 & 310 \\
\hline Percent of GDP & 3 & 9 & 10 & 13 & 13 & 10 & 7 & 3 \\
\hline Percent of exports of goods and services & 5 & 20 & 21 & 27 & 27 & 19 & 12 & 6 \\
\hline Percent of gross reserves & 15 & 42 & 43 & 52 & 50 & 37 & 26 & 14 \\
\hline \multicolumn{9}{|l|}{ Existing Fund credit 1/ 2/ } \\
\hline Millions of SDRs & 3,057 & 7,000 & 8,250 & 8,250 & 6,016 & 2,359 & 469 & 0 \\
\hline Percent of quota & 223 & 510 & 601 & 601 & 438 & 172 & 34 & 0 \\
\hline Percent of GDP & 3 & 9 & 9 & 8 & 5 & 2 & 0 & 0 \\
\hline Percent of exports of goods and services & 5 & 20 & 18 & 17 & 11 & 4 & 1 & 0 \\
\hline Percent of gross reserves & 15 & 42 & 39 & 32 & 20 & 8 & 2 & 0 \\
\hline \multicolumn{9}{|l|}{ Prospective Fund credit 1/ 2/ } \\
\hline Millions of SDRs & 0 & 0 & 1,000 & 5,000 & 8,750 & 8,750 & 7,500 & 4,250 \\
\hline Percent of quota & 0 & 0 & 73 & 364 & 638 & 638 & 547 & 310 \\
\hline Percent of GDP & 0 & 0 & 1 & 5 & 8 & 7 & 6 & 3 \\
\hline Percent of exports of goods and services & 0 & 0 & 2 & 10 & 16 & 15 & 12 & 6 \\
\hline Percent of gross reserves & 0 & 0 & 5 & 19 & 29 & 30 & 24 & 14 \\
\hline \multicolumn{9}{|c|}{ Obligations to the Fund from existing and prospective drawings $2 /$} \\
\hline Millions of SDRs & 224 & 145 & 166 & 292 & 2,665 & 4,126 & 3,460 & 3,907 \\
\hline Percent of quota & 16 & 11 & 12 & 21 & 194 & 301 & 252 & 285 \\
\hline Percent of GDP & 0 & 0 & 0 & 0 & 2 & 4 & 3 & 3 \\
\hline Percent of exports of goods and services & 0 & 0 & 0 & 1 & 5 & 7 & 5 & 5 \\
\hline Percent of gross reserves & 1 & 1 & 1 & 1 & 9 & 14 & 11 & 13 \\
\hline \multicolumn{9}{|l|}{ Obligations to the Fund from existing drawings $2 /$} \\
\hline Millions of SDRs & 224 & 145 & 111 & 202 & 2,424 & 3,751 & 1,916 & 477 \\
\hline Percent of quota & 16 & 11 & 8 & 15 & 177 & 273 & 140 & 35 \\
\hline Percent of GDP & 0 & 0 & 0 & 0 & 2 & 3 & 2 & 0 \\
\hline Percent of exports of goods and services & 0 & 0 & 0 & 0 & 4 & 6 & 3 & 1 \\
\hline Percent of gross reserves & 1 & 1 & 1 & 1 & 8 & 13 & 6 & 2 \\
\hline \multicolumn{9}{|c|}{ Obligations to the Fund from prospective drawings 2/ } \\
\hline Millions of SDRs & 0 & 0 & 55 & 90 & 242 & 375 & 1,544 & 3,430 \\
\hline Percent of quota & 0 & 0 & 4 & 7 & 18 & 27 & 113 & 250 \\
\hline Percent of GDP & 0 & 0 & 0 & 0 & 0 & 0 & 1 & 3 \\
\hline Percent of exports of goods and services & 0 & 0 & 0 & 0 & 0 & 1 & 2 & 5 \\
\hline Percent of gross reserves & 0 & 0 & 0 & 0 & 1 & 1 & 5 & 11 \\
\hline
\end{tabular}

Sources: IMF staff estimates.

1/ End of period.

2/ Repayment schedule based on repurchase obligations. 
Table 11. Ukraine: Public Sector Debt Sustainability Framework, 2005-15

(Percent of ODP, unless otherwlse Indleated)

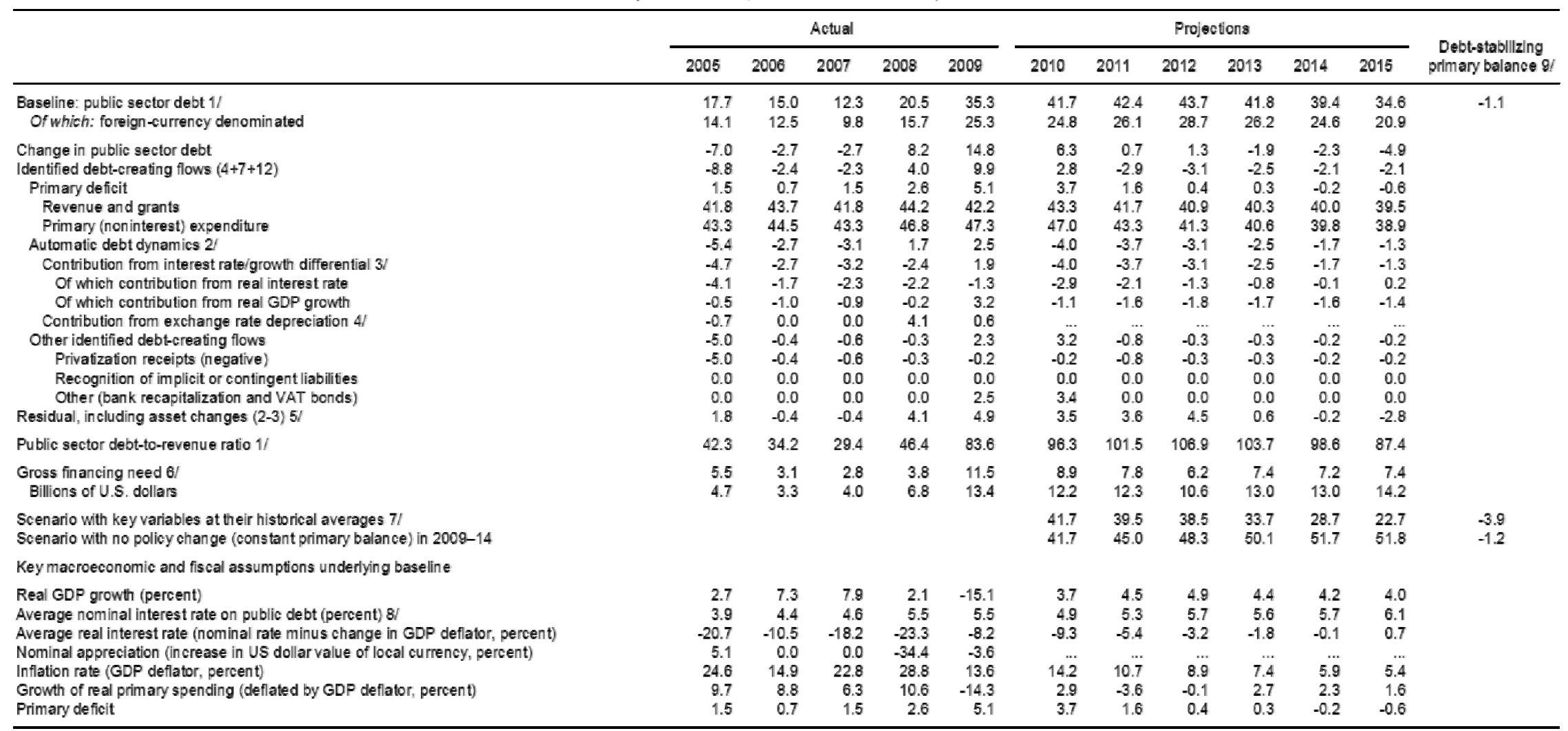

Memo item: Guaranteed debt stock

1/ The coverage of the public sector is the general government (central and local governments, as well as socila funds), and also includes State-guaranteed debt (including Naftogaz).

$2 /$ Derived as $[(r-p(1+g)-g+a e(1+r))(1+g+p+g p))$ fimes previous period debt ratio, with $r=$ interest rate; $p=$ growth rate of $G D P$ deflator; $g=$ real $G D P$ growth rate; $a=$ share of foreign-eurrency denominated debt; and $e=$ nominal exchange rate depreciation (measured by inerease in local eurrency value of U.S. dollar).

$3 /$ The real interest rate contribution is derived from the denominator in footnote $2 /$ as $r=\pi(1+g)$ and the real growth contribution as $-g$.

$4 /$ The exchange rate contribution is denived from the numerator in footnote $2 /$ as ae $(1+r)$.

$5 /$ For projections, this line includes exchange rate changes.

6/ Defined as public seetor deficit, plus amortization of medium and long-term public seetor debt, plus short-term debt at end of previous period.

7/ The key variables include real GDP growth; real interest rate; and primary balance in percent of GDP.

8/ Derived as nominal interest expenditure divided by previous period debt stock (understates interest rate given in elu sion of guaranteed debt).

9/ Assumes that key variables (real GDP growth, real interest rate, and other identified debt-creating flows) remain at the level of the last projection year:

(C) International Monetary Fund. Not for Redistribution 
Table 12. Ukraine: External Debt Sustainability Framework, 2005-15

(Percent of GDP, unless otherwise indiceted)

\begin{tabular}{|c|c|c|c|c|c|c|c|c|c|c|c|c|}
\hline & \multicolumn{5}{|c|}{ Actual } & \multicolumn{6}{|c|}{ Pro] ectlons } & \multirow{2}{*}{$\begin{array}{l}\text { Debt-stabllizing non- } \\
\text { interest current } \\
\text { account } 7 /\end{array}$} \\
\hline & 2005 & 2006 & 2007 & 2008 & 2009 & 2010 & 2011 & 2012 & 2013 & 2014 & 2015 & \\
\hline Baseline: external debt & 46.0 & 50.6 & 56.0 & 56.4 & 88.0 & 82.8 & 77.4 & 76.5 & 75.4 & 74.1 & 68.9 & -4.4 \\
\hline Change in external debt & -1.3 & 4.6 & 5.4 & 0.4 & 31.6 & -5.2 & -5.4 & -0.8 & -1.1 & -1.4 & -5.2 & \\
\hline Identified external debt-creating flows $(4+8+9)$ & -26.5 & -16.4 & -19.2 & -9.3 & 29.0 & -7.0 & -5.8 & -5.8 & -5.8 & -5.7 & -5.4 & \\
\hline Current account deficit, excluding interest payments & -5.0 & -1.3 & 0.7 & 3.2 & -4.5 & -3.1 & -3.0 & -3.1 & -3.5 & -3.4 & -3.4 & \\
\hline Deficit in balance of goods and services & -0.8 & 2.8 & 5.7 & 8.0 & 1.7 & 2.7 & 2.8 & 3.0 & 3.3 & 3.4 & 3.2 & \\
\hline Exports & 51.5 & 46.6 & 44.8 & 47.5 & 46.2 & 50.0 & 48.2 & 49.2 & 52.2 & 55.5 & 56.4 & \\
\hline Imports & 50.7 & 49.5 & 50.6 & 55.5 & 47.9 & 52.7 & 51.0 & 52.2 & 55.6 & 58.9 & 59.6 & \\
\hline Net non-debt creating capital inflows (negative) 1/ & -11.9 & -8.6 & -10.5 & -4.8 & -2.6 & -6.3 & -4.9 & -5.0 & -5.5 & -5.9 & -5.8 & \\
\hline Automatic debt dynamics $2 /$ & -9.7 & -6.4 & -9.4 & -7.8 & 36.2 & 2.3 & 2.1 & 2.3 & 3.1 & 3.5 & 3.8 & \\
\hline Contribution from nominal interest rate & 2.0 & 2.8 & 3.0 & 3.9 & 6.0 & 5.2 & 5.4 & 5.8 & 6.4 & 6.6 & 6.5 & \\
\hline Contribution from real GDP growth & -1.0 & -2.7 & -3.0 & -0.9 & 13.1 & -2.8 & -3.2 & -3.5 & -3.3 & -3.1 & -2.8 & \\
\hline Contribution from price and exchange rate changes $3 /$ & -10.7 & -6.5 & -9.4 & -10.7 & 17.1 & $\ldots$ & $\ldots$ & $\ldots$ & $\ldots$ & $\ldots$ & $\ldots$ & \\
\hline Residual, including change in gross foreign assets $(2-3) 4 /$ & 25.3 & 21.0 & 24.6 & 9.8 & 2.6 & 1.8 & 0.4 & 5.0 & 4.7 & 4.4 & 0.2 & \\
\hline External debt-to-exports ratio (percent) & 89.3 & 108.5 & 124.9 & 118.7 & 190.4 & 165.6 & 160.6 & 155.7 & 144.4 & 133.5 & 122.2 & \\
\hline Gross external financing need (billions of U.S. dollars) 5 / & 10.8 & 22.0 & 32.1 & 51.1 & 47.9 & 43.2 & 47.4 & 51.0 & 54.6 & 57.9 & 59.5 & \\
\hline Percent of GDP & 12.5 & 20.4 & 22.5 & 28.4 & 40.8 & 31.7 & 30.1 & 30.0 & 31.2 & 32.3 & 30.9 & \\
\hline Scenario with key variables at their historical averages 6 / & & & & & & 82.8 & 75.0 & 66.3 & 54.4 & 43.0 & 31.8 & -7.0 \\
\hline \multicolumn{13}{|l|}{ Key macroeconomic assumptions underlying baseline } \\
\hline Real GDP growth (percent) & 2.7 & 7.3 & 7.9 & 2.1 & -15.1 & 3.7 & 4.5 & 4.9 & 4.4 & 4.2 & 4.0 & \\
\hline GDP deflater in U.S. dollars (change in percent) & 29.3 & 16.5 & 22.8 & 23.6 & -23.2 & 12.0 & 10.5 & 2.9 & -1.6 & -1.6 & 3.1 & \\
\hline Nominal external interest rate (percent) & 5.7 & 7.7 & 7.9 & 8.7 & 6.9 & 6.8 & 7.5 & 8.0 & 8.6 & 9.0 & 9.5 & \\
\hline Growth of exports (U.S. dollar terms, percent) & 7.5 & 13.2 & 27.4 & 33.8 & -36.6 & 25.7 & 11.3 & 10.2 & 9.1 & 9.0 & 9.1 & \\
\hline Growth of imports (U.S. dollar terms, percent) & 20.4 & 22.0 & 35.4 & 38.5 & -43.8 & 27.9 & 11.7 & 10.6 & 9.4 & 8.7 & 8.6 & \\
\hline Current account balance, excluding interest payments & 5.0 & 1.3 & -0.7 & -3.2 & 4.5 & 3.1 & 3.0 & 3.1 & 3.5 & 3.4 & 3.4 & \\
\hline Net non-debt creating capital inflows & 11.9 & 8.6 & 10.5 & 4.8 & 2.6 & 6.3 & 4.9 & 5.0 & 5.5 & 5.9 & 5.8 & \\
\hline
\end{tabular}

$1 /$ Includes debt securities due to data limitations on the composition of FDI and portfolio flows.

2/ Derived as $[r-g-r(1+g)+e a(1+r)] /(1+g+r+g r)$ times previous period debt stock, with $r=$ nominal effective interest rate on external debt; $r=$ change in domestic GDP deflator in U.S. dollar terms, $\mathrm{g}=$ real GDP growth rate, $\mathrm{e}=$ nom inal appreciation (increase in dollar value of domestic currency), and $\mathrm{a}=$ share of domestic-currency denominated debt in total external debt.

$3 /$ The contribution from price and exchange rate changes is defined as $[-r(1+g)+e a(1+r)](1+g+r+g r)$ times previous period debt stock. $r$ increases with an appreciating domestic currency $(e>0)$ and rising inflation (based on GDP deflator).

4/ For projection, line includes the impact of price and exchange rate changes.

5/ Defined as current account deficit, plus amortization on medium- and long-term debt, plus short-term debt at end of previous period.

6/ The key variables include real GDP growth; nominal interest rate; dollar deflator growth; and both non-interest current account and non-debt inflows in percent of GDP.

7/ Long-run, constant balance that stabilizes the debt ratio assuming that key variables (real GDP growth, nominal interest rate, dollar deflator growth, and non-debt inflows in percent of GDP) remain at their levels of the last projection year. 
Kyiv, December 10, 2010

Mr. Dominique Strauss-Kahn

Managing Director

International Monetary Fund

Washington DC, 20431, U.S.A.

Dear Mr. Strauss-Kahn:

1. The economic recovery continues to gain strength. Growth is likely to exceed the levels anticipated under the program, supported by a gradual shift of activity from export to domestic-oriented sectors. Headline inflation, while accelerated recently due to higher grain and administrative prices, is expected to remain within program levels, with core inflation falling to single digits this year. Importantly, macro-financial risks have receded considerably, boosting confidence and allowing the government to regain access to international capital markets for the first time since 2007.

2. Performance under the program has generally been strong. All end-September performance criteria were met (Table I.1) and steady progress was made on the structural reforms due at end-September and end-October, although some reforms were implemented with small delays (Table I.2). In view of this performance and the commitments in this letter, we request the completion of the first review under the Stand-By Arrangement and the disbursement of the second tranche under the program.

3. We are confident that the policies set forth in our July 16, 2010 letter and in this supplementary letter are adequate to achieve the objectives of our program. We stand ready to take additional measures, in consultation with Fund staff, should these be required to ensure achievement of our program.

\section{Macroeconomic Framework for 2011}

4. The economic outlook for next year remains broadly favorable. Growth is projected to pick up to about $4 \frac{1}{2}$ percent, as private consumption and investment (including public spending for the Euro 2012) gain momentum. Core inflation is expected to continue to fall on the back of a still large output gap and prudent monetary policy stance. Nevertheless, planned administrative price increases will keep headline inflation relatively high in the coming months. The current account deficit is expected to remain low, around $2 \frac{1}{2}$ percent of GDP, which together with an improving market confidence and a positive overall balance of payments will support a continued build up in international reserves.

\section{Fiscal Policy}

5. We remain committed to our 2010 fiscal objectives - a general government deficit of $5 \frac{1}{2}$ percent of GDP and a combined deficit (including Naftogaz) of $6 \frac{1}{2}$ percent of GDP. However, due to higher revenue earmarking and Naftogaz's overrun, the government will 
exercise strict expenditure control, including by reducing subsidies to enterprises (UAH 3 billion), transfers to households (UAH 1 billion), and capital expenditure (UAH 2 billion).

6. Our 2011 fiscal strategy remains focused on reducing the general government deficit to 3.1 percent of GDP, which is essential to underpin our medium-term debt consolidation targets, strengthen confidence in public finances, and facilitate a further reduction in borrowing costs. To this end, we have submitted to parliament a 2011 draft budget consistent with this target (prior action). The bulk of the adjustment will be carried out by lower spending which is achieved through the following measures:

i. Initiating pension reform (see para. 11), which is expected to begin generating savings in 2011;

ii. To ensure that in 2011 the wage bill remains within budget allocations, wages for government sector employees will, on average, increase in line with inflation. In addition, the government will take measures aimed at generating savings of UAH 12.4 billion (1 percent of GDP) in budgetary spending units of all levels. This will be achieved by: eliminating vacant positions as well as positions of employees retiring in 2011; reducing staff training; limiting bonuses and benefits; shifting part of wages to budgetary institutions' own source revenue; eliminating compensation for those that perform the duties of absent employees; and limiting maximum total compensation;

iii. Keeping subsidies to enterprises (excluding Naftogaz) stable in nominal terms (through which expenditure falls by an equivalent of 0.2 percent of GDP).

7. The draft budget also includes allocations to (i) strengthen social programs to ensure that gas price hikes do not worsen living standards for the poorest (particularly for the extreme poor); and (ii) increase capital expenditure.

8. Bank recapitalization in 2011 from the budget will be strictly limited to amounts budgeted for but delayed from 2010. In addition, to keep the overall public indebtedness under control, new state guarantees in 2011 will amount to no more than UAH 15 billion (quantitative performance criterion).

\section{Fiscal Reforms}

9. We are making important progress in improving the structure of public finances, with reforms that will simplify the tax structure and strengthen tax administration and reduce government spending.

10. To strengthen the fiscal framework, we have adopted a new tax code aiming to unify and streamline tax legislation and, over time, reduce the overall tax burden while also improving revenue yields and tackling tax evasion. The new code consolidates most existing tax legislation and introduces significant tax policy and administration changes. In particular, it (i) eliminates a number of small taxes; (ii) reforms the personal income tax, introducing a 17 percent bracket for incomes above ten minimum wages; (iii) overhauls the corporate tax rate, including a two percentage point cut in 2011; (iv) envisages a reduction of the VAT rate to 17 percent in 2014; (v) introduces a property tax for large homes; and (vi) amends the tax 
deduction rules relating to writing-off non-performing bank loans against provisions (in line with NBU regulations). We believe that this reform will be revenue neutral in 2011 and the medium term.

11. We will enact a pension reform aiming to strengthen the financial foundation of the pension system to meet its obligations to the citizens of Ukraine. The reform will envisage measures to ensure a balanced budget for the Pension Fund of Ukraine and introduce personal savings accounts over the medium term. To this end, the government will submit a draft law to parliament by December 13, 2010 (prior action), aiming for approval by end2010 (structural benchmark), and implementation starting in early 2011. This will include:

- Increasing the revenues of the Pension Fund through tax reform, legalization of wages, and improving the payment of contributions;

- Gradually increasing the retirement age for women over 10 years, by adding 6 months every year to the retirement age, starting in 2011. The retirement age for men and women will be equalized by 2020 . Incentives will be provided to encourage women to stay in the workforce after the age of 55; and

- Implementing other measures including those described in the July MEFP.

12. We have initiated a comprehensive public administration reform aiming for a smaller and more efficient public administration. A functional review of ministries and central government agencies is under way, aiming to reduce overlaps and eliminate redundant functions. A more comprehensive plan, including objectives, measures, and a timetable of the reforms will be specified by end-March 2011 (structural benchmark).

13. We continue our efforts to improve tax administration, and eliminate delays in refunding legitimate VAT refund claims. While we have reduced the stock of VAT refunds arrears considerably, we do not expect to be able to eliminate them by end-December as planned. We request a modification of the end-year indicative target, increasing it to UAH 1.5 billion. We are committed to making further progress on this front, and we will eliminate these arrears in early 2011. In addition, we will set up a more systematic, timely, and transparent refund process by end-January 2011 (structural benchmark), in line with the recommendations of FAD's recent tax administration TA mission. In particular, procedures for registration of VAT payers will be improved, including the introduction of electronic reporting and accounting of VAT, introduction of a register of tax invoices, automatic compensation of honest taxpayers, and introduction of the state responsibility for failure to refund on time. We will also refrain from issuing any further VAT refund bonds, relying fully on existing refund procedures of cash refunds.

\section{Naftogaz}

14. Naftogaz's financial position improved in 2010, but still lags behind our targets, and its deficit is likely to reach UAH 15 billion. This reflects lower volumes of gas sales and the lack of adjustment in utility tariffs to end users, which in turn reduced gas payment compliance from utility companies to Naftogaz. To improve payment discipline, parliament 
has passed the law to revoke the ban on penalties on overdue utility payments (prior action), which is now effective. It has also passed legislation necessary to make the use of distribution accounts mandatory for the settlement of all utility bills.

15. For 2011, the government has prepared a financial plan aiming at a deficit of 0.4 percent of GDP for Naftogaz. The plan reflects the following policies:

a. Gradually bring the gas prices for all consumers to the level which will ensure the balanced position of Naftogaz, in particular, by approving in March 2011 a 50 percent increase in gas prices for households and utilities, effective April 15, 2011 (structural benchmark). If necessary, we will take further actions to ensure that the program deficit target is achieved.

b. Full pass-through of higher domestic gas prices to heating tariffs. The independent regulator for utility prices will be operational in January 2011. In the meantime, the National Electricity Regulation Council (NERC) has authority to set tariffs and will issue instructions (by December 16,2010) to communal utility companies to raise end-user heating tariffs (effective January 1, 2011) to reflect the August increases (prior action). Future adjustments will be based on assessment of individual cost structures of utility companies by the new regulator, if it is operational, or NERC. NERC — or the new regulator - will continue to adjust heating tariffs going forward as needed to ensure full pass-through.

c. A tight control over operational costs.

16. We have reached agreement to settle Naftogaz's commercial dispute with RosUkrEnergo (RUE) that involves the following elements: (i) Naftogaz will purchase 12.1 $\mathrm{bcm}$ in gas from Gazprom and transfer it in monthly installments to RUE over the coming year; (ii) Naftogaz will receive immediately US $\$ 1.5$ billion in payment for RUE's debt to Naftogaz (equivalent to the value of the debt minus a US\$0.2 billion fine); (iii) Gazprom will facilitate Naftogaz's new gas purchases through a US $\$ 1.5$ billion advance payment of transit fees to Naftogaz - this will be repaid over the medium term (plus a charge of 4 percent interest) at a pace that depends on the amounts of gas transited and the associated transit fees; and (iv) Gazprom has agreed to increase the annual volumes of gas transit through Ukraine to $112 \mathrm{bcm}$ from the $100 \mathrm{bcm}$ envisaged in the gas contract.

17. We are implementing a broader reform and restructuring strategy for Naftogaz and the energy sector. In addition to the measures above, the new gas sector law adopted in July in compliance with EU rules has opened the door for Ukraine to become a member of the European Energy Community. The Accession Protocol was signed on September 24, and our parliament will ratify the treaty by end-2010. We have accelerated our engagement with IFIs on the modernization of the gas transit system project. A €610 million EU macro-financial assistance loan, which includes energy sector conditionality, is expected to be signed soon and progress is being made on pilot projects for modernization of LNG facilities and the gas transit system with EBRD and EIB involvement-in line with the Brussels Declaration. In the next few months, we will make further progress towards (i) joining EITI, (ii) aligning our laws with the EU legal framework, and (iii) putting in place a sound and transparent gas market structure, including by implementing a development strategy for Naftogaz in line with the conditions for accession to the European Energy Community. 


\section{Monetary and Exchange Rate Policy}

18. We believe the recent uptick in headline inflation is temporary, linked to droughtrelated increases in food and administrative prices, and the projected 2011 inflation path remains broadly in line with program projections. However, higher inflation, along with uncertain external conditions and the recent uptake in imports on account of recovering consumption have reduced net flows into the foreign exchange market and put pressure on the exchange rate. To support our policy objectives, the NBU has increased its foreign exchange intervention and stepped up placements of CDs and repo operations, proceeded with outright sales of government securities, and sought early repayment of emergency liquidity support loans. We will remain vigilant to further developments in the foreign exchange market and possible second-round effects on inflation and, in the context of increased exchange rate flexibility, will promptly tighten our policy stance as needed to maintain core inflation on a downward trajectory and support our foreign reserves. This will include maintaining positive real refinancing rates and further accelerating the winding down, where prudent, of the stock of refinancing credits provided to banks during the crisis. Approval of new, or restructuring of existing, stabilization loans will meet the NBU's new liquidity framework stipulated in Resolution 327.

19. Going forward, we expect favorable balance of payments developments to support a more flexible exchange rate framework to be put in place. To this end, we continue our efforts to improve the functioning of the foreign exchange market and have developed and agreed with the Fund staff a time bound plan (end-October structural benchmark) which includes:

a. Realigning the regulatory framework for open foreign exchange position with best international practices. As the effects of the crisis subside, we intend to phase out Resolution 109. Open foreign exchange positions will be calculated to fully account for loan loss provision made on foreign exchange loans and foreign exchange off balance sheet items. To avoid, however, creating an immediate large demand for foreign exchange, we will announce and start implementing a gradual schedule of implementation by end-June 2011 (structural benchmark).

b. Developing hedging mechanisms and a forward exchange market. With financial stability gaining deeper roots, we also intend to allow banks to better manage exchange risk by providing a framework for: (i) forward transactions between banks to cover exposure due to client transactions and (ii) forward transactions between banks without underlying transactions by end-June 2011 (structural benchmark).

c. Strengthening the framework for exchange rate determination. By endDecember 2010, the exchange rate for government transactions with the NBU will not deviate from the contemporaneous exchange rate in the interbank market by more than 2 percent.

d. Eliminate pension tax. By end-December 2010, the government will amend the law "On surcharges for the purposes of mandatory state pension insurance" to permanently eliminate the surcharge on non-cash purchases and sales of foreign currency (structural benchmark). 


\section{Financial Sector Policies}

20. We remain committed to restoring banks' soundness. Private banks are on track to complete recapitalization by end-December (structural benchmark), in line with NBUapproved plans to inject capital and implement measures to reduce risk-weighted assets. About 60 percent of the capital needs in private banks identified during the extended audit process has been completed as of end-October. Eighteen banks are being liquidated and four banks remain under temporary administration. As banks' financial conditions improve, we will also continue to identify opportunities to phase out forbearance measures introduced during the crisis. To this end, we will cancel, by June 2011, Resolution 650. We will also establish a system of standards and accounting rules in compliance with IFRS in 2011 and make it mandatory for the banking system.

21. We have made further progress in resolving Nadra Bank. The IFRS-based audit completed in late October (structural benchmark) identified a capital shortfall of UAH 8.8 billion to reach a 10 percent Capital Adequacy Ratio. Any resolution should be based on the principles of least cost to government and adequate liquidity, and also protect the interests of the government. All loan obligations to the NBU should be settled according to an agreed schedule.

22. In addition, we will continue our efforts to resolve the state-intervened banks. The extended audit process determined there are significant additional capital shortfalls in the three previously recapitalized state-owned banks. In December, we will select internationally reputable financial and legal advisors to assess the banks' financial viability and potential. They will prepare recommendations for their resolution consistent with the principle of least cost to government. Should this assessment be delayed into 2011, we have requested an adjustor to address recapitalization or winding down costs in 2011. If at any time the NBU, in consultation with the government, determines that any of these banks is unviable, we stand ready to take appropriate action, including merging it with a viable bank or liquidating it.

23. Due diligence studies of the two state banks are underway. Two reputable international auditing firms, selected on the basis of terms of reference agreed with Fund staff, are conducting this work with a goal to conclude it by end-December (structural benchmark). These studies will assess the main financial, legal and operational risks, the adequacy of risk management and internal controls, and future viability under different scenarios.

24. With the immediacy of the financial crisis behind us, we are shifting our focus towards implementing a comprehensive strategy to effectively resolve NPLs. A working group has been established, chaired by the NBU pursuant to the President's economic reform plan. The key areas of work, and progress, are as follows:

a. Tax policy. The current tax law does not provide proper incentives for full realization of NPLs. We will amend tax policy pertaining to issues related to losses from written down bad loans, and from sale of NPLs to third parties, consistent with international best practice. We will also maintain the current formulation of bank provisions in amounts up to 40 percent of loans and other relevant assets in 2010, and 30 percent in 2011 and beyond. 
b. Insolvency legislation. Amendments to laws and regulations governing corporate insolvency will be enacted by end-June 2011 (structural benchmark), including amendments to the Law of Ukraine "On restoring the solvency of the debtor or announcing him/her bankrupt" and related laws and regulations to speed up the insolvency process, make it more transparent, and facilitate out-of-court restructuring, including through an expedited court approval of restructuring agreements negotiated out-of-court. We will also initiate work on personal insolvency legislation, in consultation with World Bank and IMF experts, as needed. We will allow the moratorium on foreclosures to expire by end-December, as planned.

c. We will also undertake reforms on issues such as judicial enforcement and security of collateral.

25. We will continue other work to strengthen the supervisory and regulatory frameworks. Legislation governing ultimate controllers and consolidated supervision have been prepared, in consultation with the IMF and World Bank. Legislation on ultimate controllers and consolidated supervision has been submitted to Rada. Key actions over the six months following their enactment will include approval of banking regulations governing ultimate controllers and consolidated supervision. We will also undertake further efforts to conclude and effectively implement MoUs with foreign banks' supervisory authorities.

26. To improve the function of record keeping and securities clearance, increase market confidence, and foster capital market development, we intend to merge in 2011 the two existing depositories, to create a single central depository, which will fully comply with internationally agreed standards. The central depository will be governed in the most transparent way, based on agreed corporate governance principles for representing interests of market players and the State. Participation of the State will imply drafting of efficient corresponding legal base and minimizing of financing from the state funds.

\section{Safeguards}

27. In the context of the second review, we will formulate an agreed plan to implement the recommendations of the 2010 safeguards assessment mission aiming to improve the NBU's autonomy and strengthen its control, reporting, and auditing frameworks.

\section{Program Monitoring}

28. The phasing of purchases under the arrangement and the quarterly review schedule are unchanged (Table I.1). The prior actions and structural benchmarks are set out in Table I.2; and the quantitative targets for end-December 2010 and for end-March and endJune 2011, and continuous performance criteria, are set out in Table I.3. The attached technical memorandum of understanding (TMU) describes the revised understandings between the Ukrainian authorities and IMF staff regarding the monitoring of the program. 
Yours sincerely,

/s/

Mykola Azarov

Prime Minister /s/

Fedir Yaroshenko

Finance Minister /s/

Volodymyr Stelmakh

Governor of National Bank of Ukraine 
Appendix Table I.1. Access and Phasing Under the Stand-By Arrangement

\begin{tabular}{lrrll}
\hline & \multicolumn{2}{c}{ Amount of purchase } & \\
\cline { 2 - 3 } Date & $\begin{array}{c}\text { Millions of } \\
\text { SDRs }\end{array}$ & $\begin{array}{c}\text { Percent of } \\
\text { quota }\end{array}$ & Conditions \\
\hline July 28, 2010 & 1,250 & 91.1 & Board approval of arrangement \\
November 30, 2010 & 1,000 & 72.9 & First review and end-September 2010 performance criteria \\
March 15, 2011 & 1,000 & 72.9 & Second review and end-December 2010 performance criteria \\
June 15, 2011 & 1,000 & 72.9 & Third review and end-March 2011 performance criteria \\
September 15, 2011 & 1,000 & 72.9 & Fourth review and end-June 2011 performance criteria \\
December 15, 2011 & 1,000 & 72.9 & Fifth review and end-September 2011 performance criteria \\
March 15, 2012 & 1,000 & 72.9 & Sixth review and end-December 2011 performance criteria \\
June 15, 2012 & 1,000 & 72.9 & Seventh review and end-March 2012 performance criteria \\
September 15, 2012 & 1,000 & 72.9 & Eighth review and end-June 2012 performance criteria \\
December 15, 2012 & 750 & 54.7 & Ninth review and end-September 2012 performance criteria \\
Total & 10,000 & 728.9 & \\
\hline
\end{tabular}

Source: IMF staff estimates. 
Appendix Table 1.2. Ukraine: Prior Actions and Structural Benchmarks

\begin{tabular}{llc}
\hline & Measure & Target Date \\
\hline
\end{tabular}

\section{Prior Actions}

1. Submit to Parliament a 2011 budget consistent with a general government deficit of 3.1 percent of GDP and the commitments included in the MEFP, paragraph 6.

2. Submit to Parliament legislation on pension reforms consistent with commitments in the MEFP, paragraph 11.

3. Pass legislation to revoke the Law “On Temporary Ban to Levy Penalties on Ukraine's Citizens for Overdue Payments of Utility Bills" (MEFP, paragraph 14).

4. NERC will issue (by December 16,2010 ) instructions to communal utility companies to raise end-user heating tariffs (effective January 1, 2011) to reflect the August increases (MEFP, paragraph 15).

\section{Structural Benchmarks}

1. Pass legislation to revoke the Law "On Temporary Ban to Levy Penalties on Ukraine's Citizens for Overdue Payments of Utility Bills".

2. Agree with Fund staff on a schedule for phasing out existing restrictions on the foreign exchange market.

3. Complete the audit for Nadra Bank before any decision on its resolution.

4. Parliamentary approval of legislation on pension reforms consistent with commitments in the MEFP, paragraph 11.

5. All banks should meet capital requirements and capital deficient banks should increase their capital in line with the approved plans (MEFP, paragraph 20).

6. Complete due diligence of state-owned banks in line with paragraph 23 of the MEFP.

7. Initiate the implementation of the reform and restructuring strategy for Naftogaz in accordance with the principles of the Brussels declaration.

8. Amend the law "On surcharges for the purposes of mandatory state pension insurance" to permanently eliminate the surcharge on non-cash purchases and sales of foreign currency (MEFP, paragraph 19).

9. Set up a more systematic, timely, and transparent VAT refund process (MEFP, paragraph 13).

10. Formulate a comprehensive public administration reform plan aiming to improve the cost efficiency of public service delivery (MEFP, paragraph 12).

11. Approve an increase in gas tariffs for all households and utility companies by 50 percent, effective April 15 (MEFP, paragraph 15).

12. Adopt amendments to the Law of Ukraine "On restoring the solvency of the debtor or announcing him/her bankrupt" and related regulations to speed up the insolvency process, make it more transparent, and facilitate out-of-court restructuring (MEFP, paragraph 24).

13. Implement a schedule to phase out Resolution 109 with a gradual reduction of banks' foreign exchange positions in line with the MEFP, paragraph 19.

14. Establish a framework to develop the forward exchange market, including by allowing transactions between banks in line with the MEFP, paragraph 19.

15. Submit to Parliament a 2012 budget consistent with a general government deficit of 2.5 percent of GDP.

End-September 2010

Reset as prior action

End-October 2010

Met with delay

End-October 2010

Met

End-December 2010

End-December 2010

End-December 2010

End-December 2010

Met

End-January 2011

End-March 2011

End-March 2011

End-June 2011

End-June 2011

End-June 2011

End-September 2011

\section{CInternational Monetary Fund. Not for Redistribution}


Appendix Table I.3. Ukraine: Quantitative Program Targets 1/

(End of period; millions of Ukrainian hryvnias, unless otherwise indicated)

\begin{tabular}{|c|c|c|c|c|c|c|c|}
\hline & \multicolumn{5}{|c|}{2010} & \multicolumn{2}{|c|}{2011} \\
\hline & $\begin{array}{c}\text { Jun. } \\
\text { Outcome 2/ }\end{array}$ & Target & $\begin{array}{l}\text { Sep. } \\
\text { Adj. Target }\end{array}$ & Outcome & $\begin{array}{l}\text { Dec. } \\
\text { Target }\end{array}$ & $\begin{array}{l}\text { Mar. } \\
\text { Target }\end{array}$ & $\begin{array}{l}\text { Jun. } \\
\text { Target }\end{array}$ \\
\hline \multicolumn{8}{|l|}{ I. Quantitative performance criteria } \\
\hline $\begin{array}{l}\text { Ceiling on the cash deficit of the general government (- implies a } \\
\text { surplus) } 3 \text { / }\end{array}$ & $\cdots$ & 47,000 & 69,556 & 59,051 & 60,000 & 10,600 & 21,200 \\
\hline $\begin{array}{l}\text { Ceiling on the cash deficit of the general government and Naftogaz } \\
\text { (- implies a surplus) } 3 /\end{array}$ & $\cdots$ & 56,000 & 78,556 & 69,786 & 71,000 & 15,000 & 27,000 \\
\hline $\begin{array}{l}\text { Floor on cumulative change in net international reserves } \\
\text { (in millions of U.S. dollars) } 4 /\end{array}$ & 19,171 & -915 & -628 & 2,095 & $-2,860$ & $-4,420$ & -560 \\
\hline Ceiling on cumulative change in net domestic assets 4/ & 67,940 & 9,916 & 7,644 & $-19,366$ & 25,733 & 43,040 & 17,800 \\
\hline Ceiling on publicly guaranteed debt $3 /$ & $\cdots$ & 15,000 & $\cdots$ & 0 & 15,000 & 15,000 & 15,000 \\
\hline \multicolumn{8}{|l|}{ II. Continuous performance criterion } \\
\hline $\begin{array}{l}\text { Non-accumulation of external debt payments arrears by the } \\
\text { general government }\end{array}$ & 0 & 0 & 0 & 0 & 0 & 0 & 0 \\
\hline \multicolumn{8}{|l|}{ III. Indicative Targets } \\
\hline Ceiling on cumulative change in base money 4/ & 219,527 & 5,040 & $\ldots$ & $-2,800$ & 5,454 & 10,460 & 15,740 \\
\hline Ceiling on stock of VAT refund arrears & $\ldots$ & 3,000 & $\ldots$ & 2,891 & 1,500 & 0 & 0 \\
\hline
\end{tabular}

Sources: Ukrainian authorities; and IMF staff estimates and projections.

1/ Definitions and adjustors are specified in the Technical Memorandum of Understanding (TMU).

2/ Data for June 2010 has been revised in line with the audit report prepared by the NBU's Internal Audit Department.

$3 /$ Data are cumulative flows from January 1 of the corresponding year.

4/ Data are cumulative flows from July 1, 2010. Data for June 2010 is a stock. 


\section{Ukraine: Technical Memorandum OF Understanding}

December 10, 2010

1. This Technical Memorandum of Understanding (TMU) sets out the understandings between the Ukrainian authorities and IMF staff regarding the definitions of the variables subject to quantitative targets (performance criteria and indicative targets) for the economic program supported under the Stand-By Arrangement, as described in the authorities' Letter of Intent (LOI) dated December 10, 2010 and the attached Memorandum of Economic and Financial Policies (MEFP). It also describes the methods to be used in assessing the program performance and the information requirements to ensure adequate monitoring of the targets. As is standard under all Fund arrangements, we will consult with the Fund before modifying measures contained in the LOI, or adopting new measures that would deviate from the goals of the program, and provide the Fund with the necessary information for program monitoring.

2. The quantitative performance criteria are shown in Table 3 of the MEFP. The definitions of these quantitative targets and the adjustment mechanisms are described in Section I below. Prior actions and structural benchmarks are listed in Table 2 of the MEFP, with corresponding definitions in Section I below. The official exchange rate is defined in Section II. Reporting requirements are specified in Section III.

3. For the purposes of the program, all exchange rates used to evaluate reserve levels and monetary aggregates are the official exchange rates determined by the National Bank of Ukraine (NBU) as of June 30, 2010. In particular, the Swiss Franc is valued at 0.9200 dollar, the Euro is valued at 1.2198 dollars, Pound Sterling is valued at 1.5052 dollars, and the Japanese yen is valued at 0.0113 dollars. The accounting exchange rate for the SDR will be 1.4789 per dollar. Official gold holdings were valued at 1,236.00 dollars per fine ounce. These program exchange rates are kept fixed over the program period. Therefore, the program exchange rate differs from the actual exchange rate set in the foreign exchange market. Furthermore, setting a program exchange rate for the purpose of computing monetary aggregates do not imply that there is any target exchange rate for policy purposes.

\section{Quantitative Performance Criteria, Indicative Ceilings, And Continuous Performance Criteria}

\section{A. Floor on Net International Reserves of Ukraine (Performance Criterion)}

\section{Definition}

4. Net international reserves (NIR) of Ukraine are defined as the dollar value of the difference between usable gross international reserve assets and reserve-related liabilities to 
nonresidents, evaluated at program exchange rates. On June 30, 2010, the NIR of Ukraine amounted to US $\$ 19,172$ million (in equivalent).

5. Usable gross international reserves comprise all readily available claims on nonresidents denominated in convertible foreign currencies, consistent with the Balance of Payments Manual (Fifth Edition) and the Special Data Dissemination Standard (SDDS) (Table A, item 1). Excluded from usable reserves, inter alia, are:

- any assets denominated in foreign currencies held at, or which are claims on, domestic institutions (i.e., institutions headquartered domestically, but located either domestically or abroad, or institutions headquartered abroad, but located domestically). Also excluded are all foreign currency claims of the NBU on domestic banks, and NBU deposits held at the Interbank Foreign Currency Exchange Market and domestic banks for trading purposes;

- any precious metals or metal deposits, other than monetary gold and gold deposits, held by the NBU;

- any assets that correspond to claims of commercial banks in foreign currency on the NBU and any reserves assets that are: (i) encumbered; or (ii) pledged as collateral (in so far as not already included in foreign liabilities, or excluded from reserve assets); or (iii) frozen; and

- $\quad$ any reserve assets that are not readily available for intervention in the foreign exchange market, inter alia, because of lack of quality or lack of liquidity that limits marketability at the book price.

6. For the purpose of this program, reserve-related liabilities comprise:

- all short-term liabilities of the NBU vis-à-vis nonresidents with an original maturity of one year or less;

- the stock of IMF credit outstanding; and

- the nominal value of all derivative positions ${ }^{1}$ of the NBU and government, implying the sale of foreign currency or other reserve assets against domestic currency.

\footnotetext{
${ }^{1}$ This refers to the notional value of the commitments, not the market value.
} 
Table A. Components of Net International Reserves

NBU Balance Sheet and

Type of Foreign Reserve Asset or Liability ${ }^{2}$ memorandum Accounts

1. International reserves

Monetary gold

1100,1107

Foreign exchange in cash

1011,1017

Demand deposits at foreign banks

1201,1202

Short-term time deposits at foreign banks

1211

Long-term deposits at foreign banks

1212

SDR holdings and Reserve Position in the IMF

IMF, Finance Department ${ }^{3}$

Securities issued by nonresidents

1302, 1305, 1307, 1308, minus 1306

2. Short-term liabilities to nonresidents (in convertible currencies)

Correspondent accounts of nonresident banks

Short-term deposits of nonresident banks

3211

Operations with nonresident customers

$3230,3232,3233$

Use of IMF credit

IMF, Finance Department

\section{Adjustment mechanism}

NIR targets will be adjusted upward (downward) by the full amount of the cumulative excess (shortfall) in program disbursements relative to the baseline projection (Table B). Program disbursements are defined as external disbursements from official multilateral creditors (World Bank, European Commission, European Investment Bank, and European Bank for Reconstruction and Development), official bilateral creditors (net), and external bond placements that are usable for the financing of the central government budget.

In addition, the NIR target for end-December 2010 will be adjusted downward by the amount of the cumulative NBU's sale of foreign currency (not exceeding US\$600 million) in the interbank market during the last five business days of December earmarked for Naftogaz to service its December gas bill paid in early January.

\footnotetext{
${ }^{2}$ The definitions used in this technical memorandum will be adjusted to reflect any changes in accounting classifications introduced during the period of the program. The definitions of the foreign accounts here correspond to the system of accounts in existence on June 30, 2010. The authorities will inform the staff before introducing any change to the Charts of Accounts of the NBU and the Commercial Banks, and changes in the reporting forms.

${ }^{3}$ Before receiving the monthly data from the IMF's Finance Department, these components will be calculated on the basis of preliminary data from the NBU and memorandum accounts.
} 
Table B. NIR/NDA Adjustment

Cumulative flows from end-June 2010 1/

In millions of US dollars at program exchange rate

Program disbursements (technical assumption for the adjuster purpose)

End-September 2010

1,850

End-December 2010

750

End-March 2011

1,000

End-June 2011

3,650

1/ In Q3 2010 these include: Eurobond placement of \$1.3 billion, EU disbursement of \$0.15 billion, EBRD disbursement of $\$ 0.3$ billion, and other project financing of \$0.1 billion. In Q4 2010 these include: World Bank disbursement of $\$ 0.5$ billion, EU disbursement of $\$ 0.3$ billion, and other project financing of $\$ 0.1$ billion; as well as \$2 billion repayment of official bilateral financing (including Russian bridge loan). In Q1 2011 these include: World Bank disbursement of $\$ 0.04$ billion, EU disbursement of $\$ 0.16$ billion, and other project financing of \$0.06 billion. In Q2 2011 these include: Eurobond placement of \$2 billion, World Bank disbursement of $\$ 0.54$ billion, and EU disbursement of $\$ 0.11$ billion.

\section{B. Ceiling on Net Domestic Assets of the NBU (Performance Criterion)}

\section{Definition}

7. Net domestic assets (NDA) of the NBU are defined as the difference between the monetary base (as defined below) and the NIR of Ukraine (as defined above). For the purpose of computing the NDA target, the NIR is valued at the program exchange rate of UAH 7.9070 per dollar and expressed in hryvnia. On June 30, 2010, the NDA of the NBU amounted to UAH 67,940 million.

\section{Adjustment mechanism}

Consistent with the NIR target adjustment mechanism (as defined above), NDA targets will be adjusted downward (upward) by the full amount of the cumulative excess (shortfall) in program disbursements relative to the baseline projection (Table B) and evaluated at the program exchange rate.

In addition, the NDA target for end-December 2010 will be adjusted upward by the amount of the cumulative NBU's sale of foreign currency (not exceeding US\$600 million) in the interbank market during the last five business days of December earmarked for Naftogaz to service its December gas bill paid in early January. 


\section{Ceiling on Monetary Base of the NBU (Base Money) (Indicative Target)}

\section{Definition}

8. The NBU's monetary base comprises domestic currency outside banks and banks' reserves, including cash in vault of commercial banks, ${ }^{4}$ and funds of customers at the NBU. Currency outside banks is defined as: Currency — banknotes and coins - (NBU accounts 3000 (net)+3001 (net)-3007A-3009A-1001A-1004A-1007A-1008A-1009A) minus cash in vault at deposit money banks (DMBs) (DMB accounts 1001A:1005A, and 1007A). Banks' reserves are defined as: cash in vault at deposit money banks (DMB accounts 1001A:1005A, and 1007A) plus DMB correspondent account deposits at the NBU in hryvnia (NBU liabilities accounts $3200,3203,3204$, and 3206) plus funds of customers at the NBU in hryvnia (NBU liabilities accounts 3230, 3232, 3233, 3234, 3250, 4731, 4732, 4735, 4736, 4738, 4739, and 4750 ), plus accrued interest on time deposits of DMBs in national currency (NBU accounts 3208L), plus accrued interest on client's current accounts in national currency (NBU liability account 3238). On June 30, 2010, the NBU's monetary base amounted to UAH 219,527 million.

\section{Ceiling on Cash Deficit of the General Government (Performance Criterion)}

\section{Definition}

9. The general government comprises the central (state) government, all local governments, and all extra budgetary funds, including the Pension, Employment, Social Insurance for Temporary Disability, State Material Reserve, Occupational Accident and Sickness Insurance, State Property Fund, and the Road Fund (UkrAvtoDor). The budget of the general government comprises: (i) the state budget; (ii) all local government budgets; and (iii), if not already included in (i), the budgets of the extra budgetary funds listed above, as well as any other extra budgetary funds included in the monetary statistics compiled by the NBU. The cash deficit of the general government is measured by means of net financing flows as:

- $\quad$ total net treasury bill sales as measured by the information kept in the NBU registry of treasury bill sales (net treasury bill sales are defined as the cumulative total funds realized from the sales of treasury bills at the primary auction and treasury securities issued for recapitalization purpose, less the cumulative total redemption of principal on treasury bills), excluding bonds issued to recapitalize Naftogaz - these are

\footnotetext{
${ }^{4}$ The definitions set out here will be modified to include any other accounts that may be identified or created in the future in connection with domestic currency issue and the deposit money banks' deposits at the NBU.
} 
included in the calculation of Naftogaz' cash deficit when they are used (as collateral for a loan, or as an outright sale) by the latter to obtain financing; plus

- $\quad$ other net domestic banking system credit to government as measured by the monetary statistics provided by the NBU (this consists of all non-treasury-bill financing in either domestic or foreign currency extended to the government by banks less the change in all government deposits in the banking system) as well as any financing extended by entities not reflected by the monetary statistics provided by the NBU; plus

- $\quad$ total receipts from privatization received by the State Property Fund and local governments (including the change in the stock of refundable participation deposits); plus

- the difference between disbursements and amortization on any bond issued by the government or the NBU to nonresidents for purposes of financing the deficit of the general government; plus

- the difference between disbursements of official foreign credits to the general government (including project loans on-lent to public enterprises) and the amortization of official foreign credits by the general government (including on lent project loans, and excluding offset-based amortization with Russia); plus

- the net sales of SDR allocation in the SDR department; plus

- the net change in government deposits in nonresident banks, or other nonresident institutions; plus

- net proceeds from any promissory note or other financial instruments issued by the general government.

10. For the purposes of measuring the deficit of the general government, all flows to/from the budget in foreign currency will be accounted in hryvnias at the official exchange rate established as of the date of the transaction.

\section{Adjustment mechanism}

The ceiling on the cash deficit of the general government is subject to an automatic adjuster based on deviations of external project financing (defined as disbursements from bilateral and multilateral creditors to the consolidated general government for specific project expenditure) from program projections (Table C). Specifically, if the cumulative proceeds from external project financing (in hryvnia evaluated at actual exchange rates): 
a) exceed program projections, the ceiling on the consolidated general government deficit will be adjusted upward by 100 percent of the excess in external project financing; and

b) fall short of program projections, the ceiling on the consolidated general government deficit will be adjusted downward by 100 percent of the shortfall in external project financing.

Table C. External Project Financing Adjustment

Cumulative flows from beginning of the year

In millions of hryvnia

External project financing (technical assumption for the adjuster purpose)

End-December 2010

2,400

End-March 2011

1,000

End-June 2011

1,500

$>$ The ceiling on the cash deficit of the general government is subject to an automatic adjuster corresponding to the upfront budgetary costs associated with the recapitalization of banks (excluding subsequent interest payments on the securities or other instruments issued for recapitalization purpose). The ceiling on the cash deficit of the general government will be adjusted upward by (but not exceed) a maximum of UAH 20 billion in 2010. The ceiling on the cash deficit of the general government for 2011 will be adjusted upward by any amount of the UAH 20 billion bank recapitalization ceiling under the program that is not used in 2010.

The ceiling on the cash deficit of the general government is subject to an automatic adjuster on the stock of budgetary arrears on social payments. Budgetary arrears on social payments comprise all arrears of the consolidated budget on wages, pensions, and social benefits owed by the Pension Fund, and the central or local governments. Budgetary arrears are defined as payments not made thirty days after they are due. Wages are defined to comprise all forms of remuneration for work performed for standard and overtime work. Pension obligations of the Pension Fund comprise all pension benefits and other obligations of the Pension Fund.

$>$ The ceiling on the cash deficit of the general government at end-December 2010 is subject to an automatic upward adjustment for the full amount of bonds used to pay VAT refunds (VAT bonds). No such bonds will be issued in 2011, and therefore there is no such adjustment for the other test dates. At the same time, the ceiling on the cash deficit of the general government at end-December 2010 will be automatically adjusted downward by (i) the difference between the total amount of bonds used as payments for VAT refunds and the amount of overdue VAT refunds at end-2009 (UAH 16.4 billion); and (ii) the stock of VAT refund arrears (as defined in section E) in excess of the ceiling on VAT refund arrears as set 
in section E. The ceiling on the cash deficit of the general government at all other test dates will be automatically adjusted downward by the stock of VAT refund arrears (as defined in Section E).

\section{E. Ceiling on VAT Refund Arrears (Indicative target)}

11. The ceiling on VAT refund arrears is set to UAH 1.5 billion at end-December 2010, and zero for all other test dates under the program. The stock of VAT refund arrears is defined as those claims that have not been settled (through a cash refund, netting out against obligations of taxpayers, payment with a government bond (VAT bond) or an official decision to reject the claim) within a specified time period after the VAT refund claim has been submitted to the STA. In 2010, this time period is 60 days, allowing for verification of the validity and payment processing of claims. In 2011, this time period will be increased to 74 days once the STA has put in place an adequate monitoring framework. VAT refund claims that have been rejected by the STA but for which an appeal has been registered in courts are not considered to be in arrears. According to this definition, the stock of VAT refund arrears as of December 31, 2009 was UAH 16.4 billion.

\section{F. Ceiling on Cash Deficit of the General Government and Naftogaz (Performance Criterion)}

\section{Definition}

12. The cash deficit of the General Government and Naftogaz is the cash deficit of the General Government as defined above plus the cash deficit of Naftogaz.

13. Naftogaz is defined as the national joint stock company "Naftogaz of Ukraine". The cash deficit of Naftogaz is measured from below the line as:

- $\quad$ net domestic banking system credit to the company (this consists of all financing in either domestic or foreign currency extended to the company by banks less the change in company deposits in the banking system); plus

- the difference between disbursements of private foreign loans to Naftogaz (including private placements) and the amortization of private foreign loans (including private placements) - for the purpose of the program, the advance transit fee paid by Gazprom as part of the settlement of the Stockholm court case will not be accounted for as a loan, but as revenue; plus

- $\quad$ the difference between disbursements of official foreign credits to Naftogaz (including project loans) and the amortization of official foreign credits (including project loans); plus 
- $\quad$ the disbursements of trade credits from Gazprom to import gas; plus

- the difference between disbursements and amortization on any bonds issued by the company; plus

- the difference between disbursements of loans from the Single Treasury Account and the amortization of loans from the Single Treasury Account; plus

- the net change in deposits of the company in nonresident banks, or other nonresident institutions; plus

- net proceeds from any promissory note or other financial instruments issued by the company; plus

- net receipts from sale of financial assets (including recapitalization or other form of treasury securities issued to the company, irrespective of their issuance date) - for the purpose of the program, the net transfer by RosUkrEnergo (including the buyback of a debt claim and collection of a penalty fee) in the settlement of the Stockholm court case will not be accounted for as a sale of financial asset, but as a revenue; plus

- $\quad$ any other forms of financing of the company not identified above.

14. For the purposes of measuring the deficit of Naftogaz, all flows in foreign currency will be accounted in hryvnias at the official exchange rate established as of the date of the transaction.

\section{Adjustment mechanism}

$>$ The ceiling on the cash deficit of the general government and Naftogaz will be adjusted upward by the amount of financing by multilateral institutions and official bilateral creditors disbursed to Naftogaz for investment projects. The baseline under the program assumes no such financing for Naftogaz.

The ceiling on the cash deficit of the general government and Naftogaz will be adjusted downward by the net transfers made by Gazprom (advance transit fee) and RosUkrEnergo (buyback of a debt claim and collection of a penalty fee) as part of the settlement of the Stockholm court case. These transfers are measured on a cumulative basis from the beginning of each calendar year.

$>$ The ceiling on the cash deficit of the general government and Naftogaz will be adjusted upward by the amount of gas transferred to RosUkrEnergo to settle the Stockholm court case. These gas transfers, capped at $12.1 \mathrm{bcm}$, will be measured on a cumulative basis from the beginning of each calendar year, and valued at prevailing gas prices (under the gas import contract with Gazprom) and official exchange rates at the time of the transactions. 


\section{G. Ceiling on the Non-Accumulation of External Debt Payments Arrears by the General Government (Continuous Performance Criterion)}

15. For the purposes of the program, an external debt payment arrear will be defined as a payment by the general government, which has not been made within seven days after falling due (including grace period, if any). The performance criterion will apply on a continuous basis throughout the program period.

\section{H. Ceiling on Publicly Guaranteed Debt (Performance Criterion)}

\section{Definition}

16. The ceiling on publicly guaranteed debt will apply to the amount of guarantees issued in 2010 and 2011 by the central (state) government. The program exchange rate will apply to all non-UAH denominated debt. New state guarantees in 2010 will amount to no more than UAH 15 billion. New state guarantees in 2011 will amount to no more than UAH 15 billion.

\section{Other Continuous Performance Criteria}

17. During the period of the Stand-By Arrangement, Ukraine will not (i) impose or intensify restrictions on the making of payments and transfers for current international transactions; (ii) introduce or modify multiple currency practices; (iii) conclude bilateral payment agreements that are inconsistent with Article VIII; and (iv) impose or intensify import restrictions for balance of payments reasons.

\section{OfFicial Exchange Rate}

\section{Determination of the official exchange rate}

18. The NBU will, on a daily basis, set the official rate at the average transactionweighted rate of the preceding day (with intraday adjustments if necessary to keep it within 2 percent of the market rate).

\section{REPORTING REQUIREMENTS}

\section{A. National Bank of Ukraine}

19. The NBU will continue to provide to the IMF on a monthly basis, no later than the 25th day of the following month, an aggregate balance sheet for the NBU and a consolidated balance sheet for the deposit money banks. 
20. The NBU will provide to the IMF, on a weekly basis, with daily data the stock of net and gross international reserves, at both actual and program exchange rates. In addition, it will provide on a weekly and monthly basis, no later than the 25 th of the following month, the full breakdown of NBU accounts included in net international reserves (defined in Table A above).

21. The NBU will provide the IMF on a daily basis with information on official foreign exchange interventions. In this context, it will also provide the detailed results of the foreign exchange auctions, in the format agreed with the IMF staff.

22. The NBU will continue to provide on its web site the daily holdings of treasury bills broken down by type of holders (including state-owned banks and private banks) at primary market prices, reports on each treasury bill auction, and provide to the IMF the monthly report on treasury bills, in the format agreed with the IMF staff.

23. The NBU will provide information on daily transactions (volumes and yields) on the secondary market treasury bills (including over the counter transactions).

24. The NBU will provide the IMF, on a weekly basis, with daily data on the total financing (including refinancing) issued by the NBU to commercial banks, broken down by original maturity of the financing, as well as transactions to absorb liquidity from the banking system.

25. The NBU will provide to the IMF, on a daily basis, the information on the banks' claims on the loans provided and the liabilities under the attracted funds in the format agreed with the IMF staff.

26. The NBU will keep providing to the IMF, on a monthly basis, general information on the NBU financing (as well as the refinancing) of the banks of Ukraine, and on the operations of mopping up (absorption) of the liquidity from the banking system (including through the CDs issuance) in the format agreed with the IMF staff.

27. The NBU will provide to the IMF, on a quarterly basis but not later than 30 days after the expiration of the reporting quarter, the report on the banking sector financial stability indicators in the format agreed with the IMF staff.

28. Every 10 days, the NBU will continue to provide the IMF with the operational monetary survey of the NBU, including any additional information that is needed for the IMF staff to monitor monetary policy and developments in the banking sector.

29. The NBU will provide to the IMF, on a monthly basis, the net domestic assets data based on the monthly balance sheets within three weeks following the end of the month. 
30. The NBU will continue to provide to the IMF the daily operational balance sheets of the NBU and commercial banks on a daily basis according to standard reporting forms, including detailed information on loans of the banking sector provided to the general government, with weekly detailed breakdown of this information by indebtedness of the central (state) government and local budgets, including in national and foreign currency, by loan and by security.

31. The NBU will provide to the IMF, on a monthly basis, projections for external payments falling due in the next twelve months. The data on actual settlement of external obligations, reflecting separately principal and interest payments as well as actual outturns for both the public and private sectors, shall be provided on a quarterly basis, within 80 days following the end of the quarter.

32. The NBU will provide to the IMF, on a quarterly basis, the stock of short- and longterm external debt (including arrears) for both public and private sectors.

33. The NBU will provide to the IMF on a daily basis aggregated data on main currency flows, including government foreign receipts and payments by currencies as well as currency breakdown of interbank market operations. The NBU will continue to provide daily information on exchange market transactions including the exchange rate.

34. The NBU will provide to the IMF reports N 381.25; 381.26 with information on reserve requirements and reports on $\mathrm{CD}$ operations when performed.

35. The NBU will continue to provide on a monthly basis, no later than 25 days after the end of the month, banking system monitoring indicators in an agreed format. This includes inter alia data on nonperforming loans (substandard, doubtful, and loss criterion).

36. The NBU will provide to the IMF consolidated banking sector data and aggregated data (without specifying the names of the banks) for the largest banks (accounting for at least 80 percent of the total banking system assets) on a quarterly basis, no later than 30 days after the end of the quarter: (i)structure of assets, liabilities, capital, revenues and expenditures; (ii) loan classification (standard, watch, substandard, doubtful, loss); (iii) provisions for all assets (required and actual); (iv) foreign currency denominated lending and deposits; (v) capital adequacy ratios for normative and regulatory capital (Tier II and I), normatives $\mathrm{H} 2$ and $\mathrm{H} 3$; weighted averages based on banks' total assets; and (vi) liquidity normatives H5 and H6; weighted averages based on banks' total assets.

37. The NBU will continue to provide detailed quarterly balance of payments data in electronic format within 80 days after the end of the quarter.

38. The NBU will provide data on credit to nongovernment units that are guaranteed by the NBU on a monthly basis no later than 25 days after the end of the month. 
39. The NBU will inform IMF staff if the Treasury does not pay interest or principal on treasury bills due to the NBU, deposit money banks, or nonbank entities and individuals. In such case, the NBU will provide information on outstanding interest and principal payments.

40. The NBU will inform IMF staff of any changes to reserve requirements for deposit money banks.

41. The NBU will communicate (electronically) to the IMF staff any changes in the accounting and valuation principles applicable to the balance-sheet data and will notify the staff before introducing any changes to the Charts of Accounts and reporting forms of both the NBU and the commercial banks.

42. The NBU Internal Audit Department will continue to provide an assurance report to the Fund, no later than six weeks after each test date, confirming that: (i) the monetary data are in accordance with program definitions and have been verified and reconciled to accounting records; and (ii) that there have been no changes to the chart of accounts or valuation methods that would impact the data reporting.

43. The NBU will continue to provide the Fund with a copy of the annual management letter from the external auditor within six weeks of completion of each audit. As required under the Fund's safeguard policy, this will remain in effect for the duration of the arrangement and for as long as credit remains outstanding.

\section{B. Ministry of Finance}

44. The Treasury will continue to provide to the IMF its report on daily operational budget execution indicators, on a 10-day basis data on revenue of the state, local government, and consolidated budget revenues.

45. The Treasury will continue to provide to the IMF in electronic form monthly and quarterly treasury reports, no later than 25 and 35 days after the end of the period respectively. The Treasury will continue to provide to the IMF in electronic form the final fiscal accounts at the end of each fiscal year, no later than March of the following year. Inter alia, these reports will provide expenditure data by programs and key spending units, as well as based on standard functional and economic classifications. In addition, quarterly reports will contain standard information on budget expenses to cover called government guarantees.

46. The Ministry of Finance will continue to provide monthly reports 1.P0 on actual tax revenue and 1.P6 on tax arrears, no later than 25 days after the end of each month.

47. The Ministry of Finance will report monthly data on the public wage bill in line with the template agreed with the IMF staff. It will also provide monthly reports on the execution of the Stabilization Fund as well as the Road Fund. 
48. The Ministry of Finance will report to the IMF on a monthly basis, no later than 15 days after the end of the month, the cash deficit of the general government, with details on budget execution data for privatization receipts of the state and local governments; disbursements of external credits (including budget support and project loans for on-lending) to the consolidated budget and amortization of external debt by the consolidated budget; net domestic borrowing of the general government, including net t-bill issuance, issuance of other government debt instruments, and change in government deposits.

49. The Ministry of Finance will also provide, on a monthly basis, information on the borrowing (disbursements, interests and amortization) for the following state-owned companies or agencies: Naftogaz, UrkAvtoDor, State Mortgage Institution and the National Agency in Charge of preparation and Conduction of Euro-2012 Soccer Championship, in line with the format agreed with IMF staff.

50. The Ministry of Finance will provide data on the stock of all budgetary arrears on a monthly basis, no more than 25 days after the end of the month, including separate line items for wages, pensions, social benefits, energy, communal services, and all other arrears on goods and services. The Treasury will report monthly data on accounts payable for state and local budgets (economic and functional classification).

51. The Ministry of Finance will provide monthly information, no later than 25 days after the end of each month, on the amounts and terms of all external debt contracted or guaranteed by the general government.

52. The Ministry of Finance will provide to the IMF in electronic form on a monthly basis, no later than 25 days after the end of the month, (a) data on the outstanding stock of domestic and external debt of the state and local budgets (including general and special funds), (b) the standard files planned and actual external debt disbursement, amortization, and interest payments (including general and special funds), broken down in detail by creditor categories as agreed with Fund staff, and (c) the report on external debt amortization and interest payments by days and currencies. The Ministry of Finance will also report the accumulation of any budgetary arrears on external and domestic debt service.

53. The Ministry of Finance will provide to the IMF monthly debt (domestic and external) amortization schedules updated on a weekly basis.

54. The Ministry of Finance will provide data on external and domestic credit to nongovernment units that is guaranteed by the government (amount of sovereign guarantees extended by executive resolutions and actually effectuated; total amount of outstanding guarantees and list of their recipients) on a monthly basis no later than 25 days after the end of the month.

55. The Ministry of Finance will provide data on the approved budgets and quarterly operational data (daily for the Pension Fund only) on the revenue, expenditures, and arrears, 
and balance sheets of the Pension Fund (detailed data on the breakdown of revenues and expenditure by main categories are expected for this Fund), Social Insurance Fund, Employment Fund (detailed data on the breakdown of revenues and expenditure by main categories are expected for this Fund), Occupational Accident and Sickness Insurance Fund, and any other extra budgetary funds managed at the state level no later than 50 days after the end of each quarter (each month in case of the Pension Fund). Any within-year amendments to the budgets of these funds will be reported within a week after their approval. The Ministry of Finance will also report the annual financial statement including the final fiscal accounts of those funds at the end of each fiscal year, no later than April of the following year.

56. The Ministry of Finance will report semi-annual data on the number of employees of budgetary institutions financed from the central (state) and local budgets, starting from January 2010. After any public sector wage increase, the Ministry of Finance will provide an estimate of its costs for the current and two subsequent fiscal years, for the state and local government budgets.

57. The Ministry of Finance will provide, no later than 15 days after the end of each month, monthly data on the budgetary costs associated with the recapitalization of banks. This cost includes the upfront impact on the cash deficit of the general government of the recapitalization of banks as well as the costs associated with the payment of interests.

58. The Ministry of Finance and the Treasury will provide, in line with the template agreed with the IMF staff, weekly data on the outstanding balance of the single Treasury account (including its foreign exchange component) compartmentalized into funds ascribed to (a) general fund of the state budget; (b) special fund of the state; (c) local budgets; and (d) other funds as well as data on net outstanding temporary loans to Pension Fund and local budgets.

\section{State Tax Administration}

59. The State Tax Administration (STA) will provide monthly data, no later than 25 days after the end of the month, on tax arrears, inclusive of deferred payments, interest and penalties outstanding, in the following format:

\begin{tabular}{|c|c|c|c|c|c|c|c|c|c|c|}
\hline & \multicolumn{4}{|c|}{ Beginning Stock } & \multirow{2}{*}{$\begin{array}{c}\text { Netting } \\
\text { out } \\
\text { during } \\
\text { month }\end{array}$} & \multirow{2}{*}{$\begin{array}{l}\text { Deferrals } \\
\text { during } \\
\text { month }\end{array}$} & \multirow{2}{*}{$\begin{array}{l}\text { Write- } \\
\text {-offs } \\
\text { (arrears } \\
\text { written off } \\
\text { during } \\
\text { month) }\end{array}$} & \multirow{2}{*}{$\begin{array}{c}\text { Collections } \\
\text { of } \\
\text { outstanding } \\
\text { debt at } \\
\text { beginning } \\
\text { of month }\end{array}$} & \multirow{2}{*}{$\begin{array}{c}\text { New } \\
\text { Arrears (tax } \\
\text { liabilities } \\
\text { becoming } \\
\text { overdue } \\
\text { during month) }\end{array}$} & \multirow{2}{*}{$\begin{array}{l}\text { Ending } \\
\text { Stock }\end{array}$} \\
\hline & Total & Principal & Interest & Penalties & & & & & & \\
\hline $\begin{array}{l}\text { Tax } \\
\text { arrears }\end{array}$ & & & & & & & & & & \\
\hline
\end{tabular}


60. The STA will continue to provide on a quarterly basis, no later than 2 months after the end of the quarter, a listing of all tax exemptions granted, specifying the beneficiary the exemption provided, the duration, and the estimated subsequent revenue loss for the current fiscal year.

61. The STA will continue to provide monthly information, no later than 25 days after the end of the month, on VAT refunds in the following format: (i) beginning stock of refund requests; (ii) refund requests paid in cash; (iii) refunds netted out against obligations of the taxpayer; (iv) denied requests; (v) new refund requests; (vi) end-of-period stock of requests; and (vii) stock of VAT refund arrears according to the definition in paragraph 11 (unsettled VAT refund claims submitted to the STA more than 60 days before the end-of-period.

\section{Ministry of Economy and Ministry of Fuel and Energy}

62. The Ministry of Economy will provide quarterly information on actual levels of communal service tariffs in all regions for major services (heating, water supply, sewage and rent) and their level of cost recovery. In addition, the Ministry of Economy, the Ministry of Housing and Municipal Economy of Ukraine, and the National Energy Regulatory Commission will provide the methodology underlying the tariff calculations for full cost recovery, including electricity and gas.

63. For each month, no later than the 25th of the following month, the government (based on information by the Ministry of Fuel and Energy, the Ministry of Economy, STA, MoF, NERC, and Naftogaz) will provide IMF staff with information in electronic form (in an agreed format) on financial indicators in the gas, electricity and coal sectors, including sales, tariffs, arrears, payments to the budget, subsidies, and debt.

64. For each month, no later than the 25th of the following month, the Ministry of Fuel and Energy (based on information by Naftogaz) will provide IMF staff with information in electronic form (in an agreed format) on the cash deficit of the company, as defined above. The end-quarter reports will have been audited.

65. For each month, no later than the 25th of the following month, the Ministry of Fuel and Energy (based on information by Naftogaz) will provide IMF staff with information on all flows related to the settlement of the Stockholm court case. This includes transfers made by Gazprom (advance transit fee) and RosUkrEnergo (buyback of a debt claim) and collection of a penalty fee; purchases of gas to be transferred to RUE; and actual amounts of gas transferred to RUE.

\section{E. State Statistics Committee}

66. The state Statistics Committee and Naftogaz will provide to the IMF, on a monthly basis, no later than 45 days after the end of the month, data on prices, volumes, and payments for imported and exported oil and natural gas by country of origin and destination. 


\section{Statement by the Staff Representative on Ukraine \\ December 22, 2010}

1. This statement provides information that has become available since the Staff Report was circulated to the Executive Board on December 10, 2010. The information does not alter the thrust of the staff appraisal.

2. The four prior actions for the first review have been met:

- $\quad$ The government has submitted to parliament the 2011 budget consistent with a general government deficit of 3.1 percent of GDP. The draft budget has since been approved in the first of three readings. Final approval is expected by end-year.

- $\quad$ The government has submitted to parliament a draft pension reform law consistent with commitments under the program. Approval by end-December is a structural benchmark under the program.

- $\quad$ NERC (the temporary regulator for utility prices) has instructed communal utility companies to raise end-users heating tariffs to reflect the gas price increase that took place in August. The new tariffs will be effective on January 1, 2011.

- $\quad$ Parliament has passed legislation that revoked the temporary ban to levy penalties on citizens for overdue payments of utility bills. 
December 22, 2010

\section{IMF Completes First Review Under Stand-By Arrangement with Ukraine and Approves €1.2 Billion Disbursement}

The Executive Board of the International Monetary Fund (IMF) today completed the first review of Ukraine's economic performance under the program supported by a Stand-By Arrangement (SBA). The completion of the review enables the immediate disbursement of SDR 1 billion (about $€ 1.2$ billion, or US\$1.5 billion). Drawing the full amount would bring total disbursements under the program to SDR 2.25 billion (about $€ 2.6$ billion, or US\$3.4 billion).

Ukraine's 29-month SBA was approved on July 28, 2010, in the amount of SDR 10 billion (about $€ 11.7$ billion, or US\$15.3 billion) in support of the authorities' economic adjustment and reform program (see Press Release No. 10/305). The SBA entails exceptional access to IMF resources, amounting to 728.9 percent of Ukraine's quota in the Fund.

Following the Executive Board's discussion of Ukraine, Mr. John Lipsky, First Deputy Managing Director and Acting Chair, made the following statement:

"Ukraine's satisfactory performance under the economic program supported by the Stand-By Arrangement, along with strong policy commitments for the coming year, are supporting a steady recovery in confidence and broadening of economic activity. The authorities remain committed to timely implementation of fiscal, energy, and financial sector reforms that are essential to achieve program objectives. Sustained implementation of reforms will help entrench macroeconomic stability, boost confidence, facilitate access to capital markets, and promote more balanced and robust growth.

"Fiscal adjustment remains at the core of the program. In the near-term, swift approval of the 2011 budget consistent with program targets, along with tight control over budget execution and efforts to improve tax administration, will be crucial. Longer term fiscal sustainability depends crucially on structural reforms in the areas of pension, public administration, and 
state-owned enterprises. In this regard, the timely approval and implementation of the pension reform legislation submitted to parliament will be key.

"Recent steps to strengthen the financial position of Naftogaz, including through revenue collection improvements, are also important. Further efforts, including gas price increases and structural reforms, are needed to create a more viable and transparent energy sector.

"Important progress has been made in rehabilitating and restoring confidence in the financial system, including private bank recapitalization and steps toward strengthening the supervisory framework. It is now timely to expedite the implementation of measures necessary to tackle the problem of sizeable impaired assets in the banking system that are hindering financial sector's support for a sustainable economic recovery." 